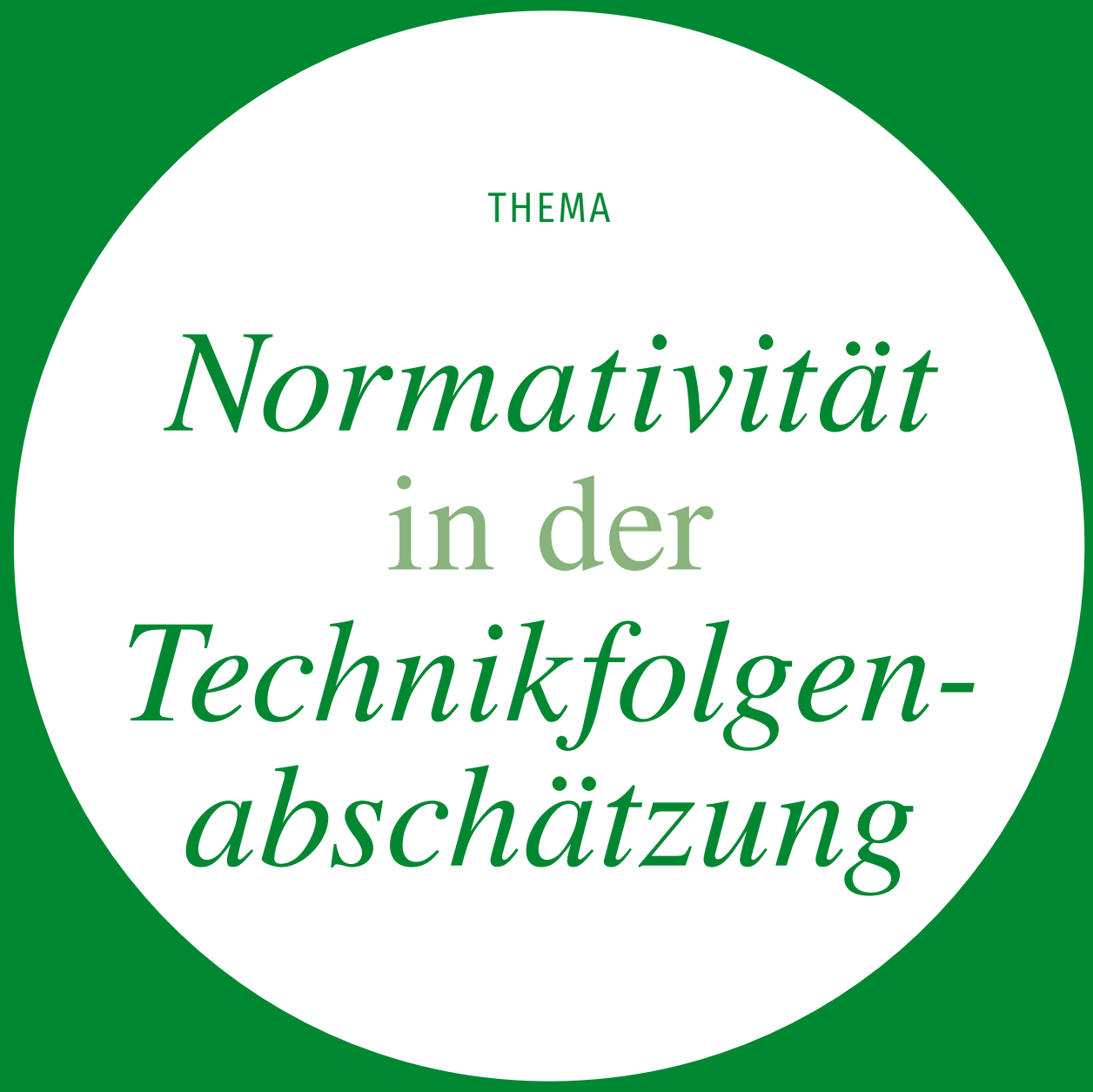

Neutralität galt lange als unhinterfragte Grundlage im Selbstverständnis von Technikfolgenabschätzung. Dieser Mythos schränkte eine Debatte über normative Aspekte ein, die angesichts manch autoritärer Tendenzen auch in westlichen Demokratien heute umso dringender geführt werden sollte. Ein TATuP-Thema herausgegeben von Linda Nierling (ITAS, KIT) und Helge Torgersen (ITA, Wien). 


\section{Normativität in der \\ Technikfolgenabschätzung}

Einleitung in das TATuP-Thema

Linda Nierling, Institut für Technikfolgenabschätzung und Systemanalyse (ITAS), Karlsruher Institut für Technologie (KIT),

Karlstraße 11, 76133 Karlsruhe (linda.nierling@kit.edu), (D orcid.org/0000-0001-9129-550X

Helge Torgersen, Institut für Technikfolgen-Abschätzung, Österreichische Akademie der Wissenschaften

(Helge.Torgersen@oeaw.ac.at), (1) orcid.org/0000-0002-8863-7959

Neutralität galt lange als unhinterfragte Grundlage im Selbstverständnis von Technikfolgenabschätzung (TA). Dieser Fokus verstellte allerdings den Blick darauf, dass normative Aspekte nicht außer Acht gelassen werden dürfen - sei es in den Ergebnissen von TA-Analysen oder in normativen Setzungen, die im TA-Prozess auftreten. Im TATuP-Thema dieses Heftes wird "Normativität in der TA“ auf drei Ebenen adressiert: in der Funktion von TA als Politikberatung, im Kontext des TA-Forschungsprozesses und in der Auseinandersetzung um ihren „normativen Kern“. Angesichts manch autoritärer Tendenzen auch in westlichen Demokratien ist die Debatte um die Rolle von Normativität in der TA heute besonders aktuell.

\section{Normativity in technology assessment}

Introduction to the special topic

Neutrality has long been considered a key prerequisite of technology assessment (TA). The need to stay neutral often obscured the importance of normative aspects of TA - be it in the findings or in normative settings in the TA process. The special topic addresses normativity in TA at three levels: (1) regarding TA's role as policy advisor, (2) in the context of the research process, and (3) with respect to its "normative core". The problem of normativity in TA gains significance in the light of recent authoritarian tendencies also in Western democracies.

Keywords: normativity, values, neutrality, normative core, policy advice

This is an article distributed under the terms of the Creative Commons Attribution License CCBY 4.0 (https://creativecommons.org/licenses/by/4.0/)

https://doi.org/10.14512/tatup.28.1.11
„Die meisten TA-Analytiker fassen nun das Technology Assessment als ein ,normatives Instrument' auf, dessen Aufgabe es ist, plausible - oder auch wünschbare alternative Zukünfte zu entwerfen (Szenarien) und Wege (Optionen, Maßnahmen) zu beschreiben und in Bezug auf Bedingungen und Folgen zu analysieren, auf denen diese ,Zukünfte' erreicht werden können."

(Paschen 1986, S. 35)

Dieses Zitat aus den Anfängen der Technikfolgenabschätzung (TA) im deutschsprachigen Raum zeigt auf, dass das Thema der Normativität, d. h. das Problem der ,Nicht-Trennbarkeit von Fakten und Normen“ (Kollek in diesem Heft, S. 16) von Beginn an in der TA aufgeworfen wurde. Dass dies zunächst nicht theoretisch ausdifferenziert wurde (Böschen und Dewald 2018), lässt sich auch mit der Strategie der in dieser frühen Phase etablierten TA-Einheiten an nationalen Parlamenten erklären. Diese wollten den Anschein von Parteilichkeit vermeiden und so galt weniger das Offenlegen normativer Bezüge, sondern vielmehr Neutralität als Voraussetzung für eine unabhängige Politikberatung. Gut 30 Jahre später ist Neutralität als Mythos der TA entzaubert (Torgersen 2019).

Das Ausblenden der Normativitätsfrage war solange wenig problematisch wie Demokratie, Gewaltenteilung und eine Art sozialverträgliche Technikgestaltung über Parteigrenzen hinweg als selbstverständlich galten. Dieser Konsens erscheint angesichts populistisch-autoritärer Tendenzen in Politik und Gesellschaft heute gefährdet. Für die TA erhebt sich damit die Frage nach den eigenen Werten und Normen: Ist der Bezug auf Neutralität heute noch zeitgemäß? Welche Konsequenzen - Unparteilichkeit bewahren oder Position beziehen - ergeben sich aus Wertekollisionen (Delvenne und Parotte 2019)? Und wie lässt sich Normativität für die Technikfolgenabschätzung fassbar machen?

Die in diesem TATuP-Thema versammelten Beiträge sowie das Interview in diesem Heft zeigen, dass diese Fragen über aktuelle politische Bezüge weit hinausgehen. So werden in der 
TA-Community derzeit normative Bezüge aus verschiedenen Blickwinkeln diskutiert: als theoretische Anforderungen (Böschen und Dewald 2018), als „Politics der TA“ (Hennen und Nierling 2019) oder mit Bezug auf die Praxis (wie auf der TA18 in Wien). Außerdem ist ,die TA “vielgestaltig: In der politischen Beratung aktiv, erarbeitet sie ebenso originäres wissenschaftliches Wissen und formiert sich als inter- und transdisziplinäre Wissenschaftsdisziplin über Ländergrenzen hinweg (Hennen und Nierling 2015; Hahn et al. 2018). Beides bringt Herausforderungen für die Arbeitsweise und Themenwahl sowie für die Selbstverortung von TA-Forscherinnen und -Forschern im politischen und Innovationssystem und damit für die Wahl normativer Bezugspunkte mit sich (Dobroć et al. 2018; Dusseldorp 2014).

\section{Neutralität ist als Mythos der TA entzaubert.}

Nun ist die Operationalisierung von Normativität für die TA kein einfaches Unterfangen, nicht zuletzt, weil Begriff und Konzept lange Traditionen in Philosophie, Soziologie und Rechtswissenschaft haben. Diese umfassend für die TA aufzubereiten, kann hier nicht Gegenstand sein; eine vielsagende Definition soll aber in Erinnerung gerufen werden. So lässt sich Normativität verstehen als „Bezeichnung für Aussagen, in denen eine Bewertung ausgedrückt wird (z. B. richtig, gut) verbunden mit der Forderung, sich dieser Bewertung anzuschließen“" (Woesler und Lautmann 2011, S. 476). Beide Elemente von Normativität sind für die TA relevant: zum einen die Bewertung von Aussagen, zum anderen der damit verbundene Aufforderungscharakter, diese Bewertung zu teilen. Gerade letzteres ist eine wesentliche Herausforderung für die TA und wohl auch Grund dafür, dass sich Normativität und TA nicht so einfach zusammenbringen lassen.

\section{Beiträge in diesem Heft}

Dieses Verhältnis offen zu legen, epistemische Unterschiede zwischen Fakten und Normen in der TA-Praxis zu thematisieren und das inhärent Normative der TA überhaupt diskutierbar zu machen, ist Anliegen dieses TATuP-Themas. Die versammelten Beiträge adressieren dabei drei Ebenen: (1) die TA in ihrer beratenden Funktion, (2) die Reflexion ihrer wissenschaftlichen Praxis und (3) ihre Selbstverständigung.

\section{Drei Ebenen der Normativität}

Die erste Ebene betrifft die Funktion der TA als Instrument der Politik- bzw. Gesellschaftsberatung. Die Forderung nach Neutralität wurde bereits im Gründungsdokument des Office of Technology Assessment von 1972 festgeschrieben als ,providing neutral, competent assessments about the probable beneficial and harmful effects of new technologies" (Bimber 1996, S. 26). Der Neutralitätsanspruch war Voraussetzung, um TA im politischen Kontext zu installieren - auch wenn dies letztlich von der geschickten Positionierung zwischen ,hostile positions from relevant players in the innovation system and a defence against accusations of allegedly following a hidden agenda of ,technology arrestment ““ (Hennen und Nierling 2015, S. 7) abhängig war.

Die Praxis gestaltete sich mitunter schwierig. Das OTA erprobte unterschiedliche Neutralitätsstrategien (Bimber 1996), etwa eine Orientierung an gemeinwohlorientierter „besserer“ Politik, die aber als Präferenz für die Demokratische Partei ausgelegt wurde. Die folgende Phase strikter Neutralität führte zu realitätsfernen Berichten und Bedeutungsverlust. Erfolgreicher war man mit einer Gleichgewichtspolitik, die konkurrierende Interessen gemäß dem Prinzip ,something for everybody“ bediente. Ein Nachhall dieser Differenzen lässt sich noch heute an verschiedenen Parlamenten beobachten: So enthält sich etwa das britische Parliamentary Office of Science and Technology (POST) jeglicher Stellungnahme, während der dänische Technologierat eigenständige Empfehlungen gab (Nentwich 2016). Ob TA in der Praxis normative Positionen vertritt, ist also keine ontologische Frage, vielmehr geht es um die strategische Verbindung von Analyse und Bewertung in den jeweiligen spezifischen Kontexten von TA.

Wie die Beiträge in diesem Heft deutlich machen, ist das Parlament jedoch nicht der einzige Adressat, auch wenn parlamentarische TA für die historische Entwicklung wichtig war. So zeigen Kastenhofer et al., dass Öffentlichkeit, Verwaltung und viele andere gesellschaftliche Akteure unterschiedliche, auch normative Anforderungen an TA stellen (siehe dazu auch Ganzevles et al. 2014). Allerdings ziehen Beziehungen zu den Auftraggeberinnen und Auftraggebern bzw. Adressatinnen und Adressaten von TA-Studien Kastenhofer et al. zufolge keine direkten Abhängigkeiten nach sich. Angesichts der dabei entstehenden Spannungsfelder plädiert Kollek für einen Ersatz (fiktiver) Neutralität durch ,reflexive“ Normativität, d.h. das ständige Bewusstmachen normativer Bezüge, unter denen TA durchgeführt wird, um die oft unbewussten Selektivitäten im TA-Prozess zu vermeiden (siehe auch das Konzept des „doing reflexivitiy“ in Bauer und Kastenhofer 2019). Diese Selektivitäten können sowohl die Inhalte der Beratung als auch deren konzeptionelle Grundlage betreffen - Lucivero et al. unterscheiden daher zwischen einer ,in-normativity“, die sich aus den Werten und Normen der Teilnehmerinnen und Teilnehmer am TA-Prozess und denen der durchführenden Praktikerinnen und Praktikern speist, und einer „,meta-normativity“, mit der die grundlegenden inhärenten Ziele der TA gemeint sind. Einen Vorschlag für die praktische Umsetzung der Forderungen nach normativer Transparenz auf der Basis eines moralpragmatischen Ansatzes liefert Weydner-Volkmann mit dem Konzept der moralischen Landkarten, mit deren Hilfe sich die angewandte Ethik in den TA-Prozess integrieren und für TA-Analysen operationalisieren lässt.

Die zweite Ebene betrifft den Umgang mit offenen oder verdeckten normativen Setzungen im TA-Forschungsprozess. Wie 
in anderen wissenschaftlichen Disziplinen gibt es diesbezüglich auch in der TA viele Beispiele (Dieckhoff 2015). Mit dem Konzept der ,in-normativity“ gelingt es Lucivero et al. in diesem Heft, Annahmen und Werturteile in unterschiedlichen Phasen zu thematisieren. In diesem Sinne untersuchen auch Böschen et al. den Umgang mit Indikatoren im Forschungsprozess am Beispiel der Nachhaltigkeitsbewertung. Sie unterscheiden, ob die Umgebung eines Nachhaltigkeitsproblems ,kontextoffen“ in die Bewertung einfließt oder ob die Indikatoren ,kontextneutralisierend“ nur ein Binnenproblem abbilden. Auf forschungsmethodischer Ebene schlagen Mader et al. ein computergestütztes Verfahren vor, um Werthaltungen von Teilnehmerinnen und Teilnehmern in partizipativen Verfahren transparent zu machen und so normative Ein- der Nachhaltigkeit, soziale[n] Ausgleich und gerechte Verteilung von Risiken und Chancen sowie de[n] Vorrang von gesellschaftlichen Problemen vor rein ökonomischen“.

Ist der normative Kern der TA also mit Gemeinwohl, demokratischen Werten und Verfahren verbunden? Wie stark soll TA Werte und Werthaltungen integrieren und sich auf dieser Basis in gesellschaftliche Diskurse einmischen? Ist der TA gar eine gesellschaftliche „Normenbegründungsfunktion“ (Woopen und Mertz 2014, S. 46) inhärent? Einen Zugang zu der Vielschichtigkeit dieser Fragen bietet das Interview mit Grunwald und Delvenne in diesem Heft. Beide betonen, dass TA seit jeher dem Wertekanon der Aufklärung und einer soliden, gelebten Demokratie verpflichtet sei. Allerdings ziehen sie jeweils unterschied-

\section{Wie stark soll TA Werte und Werthaltungen integrieren und sich auf dieser Basis in gesellschaftliche Diskurse einmischen?}

stellungen für die diskursive Vielfalt nutzen zu können. Während diese Beiträge im Forschungsprozess ansetzen, schlagen Hillerbrand et al. vor, normative Setzungen an dessen Anfang zu stellen. Ihr Capability-Ansatz als Rahmenkonzept für TA-Analysen stellt subjektive Wertsetzungen dezidiert ins Zentrum. Etwa bei der Digitalisierung des Energiesektors kann ein solcher Ansatz normative Bezugspunkte schaffen, um unterrepräsentierte Ansichten offenzulegen und so einen kognitiven Mehrwert für die TA zu erzielen. Diese Beiträge werfen zwar nur Schlaglichter auf den TA-Forschungsprozess, zeigen aber mit großer Deutlichkeit, dass das Ausleuchten und der Umgang mit normativen Elementen einen reflexiven Ansatz erfordern.

Jenseits funktionaler Fragen und des Problems normativer Setzungen im Forschungsprozess fordern die Beiträge auf einer dritten Ebene auch dazu auf, sich über Wertgrundlagen der TA $\mathrm{zu}$ verständigen. Kann es so etwas wie einen normativen Kern geben? Ist angesichts ihrer heutigen Vielgestaltigkeit eine Verständigung über ein ,shared ethos of TA“ (Hennen und Nierling 2019, S. 20) überhaupt möglich? Wie Hennen in diesem Heft zeigt, ist das Problem, ob Werte in der Wissenschaft offen vertreten werden sollten so neu nicht, befasste sich doch bereits Max Weber intensiv mit der wissenschaftlichen Wert(urteils)freiheit. Diese Debatte weist erstaunliche Bezüge zum hier diskutierten Problem auf: Es geht nicht darum, $o b$ Wissenschaft (und damit TA) normativ sei - sie ist es notwendigerweise - , sondern darum, wie man mit dieser Normativität umgehen könne.

Wie lässt sich die Normativität von TA also inhaltlich füllen? Nach Lucivero et al. stellt die ,meta-normativity“ von TA ,the embedded normative ideal that a more pluralistic process will produce better outcomes and benefits for society" dar (S. 23 in diesem Heft). Dahingegen plädiert Grunwald (2019, S. 5) etwas breiter für ,TA's obligation to transparency, inclusion, and democratic debate“ als kleinstem gemeinsamen (normativen) Nenner. Torgersen (2019, S. 26) versteht hierunter die „Werte liche Schlüsse daraus, was mitunter erhebliche Auswirkungen auf die Praxis hat. Nach Grunwald erlaubt die notwendige Inklusion unterschiedlicher Positionen im TA-Prozess keine Präferenz für bestimmte sachliche Lösungen. Delvenne hingegen fokussiert auf die normative Verankerung der TA auch auf der Faktenebene; demnach müsse TA sich zu bestimmten Positionen eindeutig bekennen.

Die theoretische Verständigung auf geteilte Werte der TA und der praktische Umgang damit in Beratung und Forschung bleiben also Gegenstand der Auseinandersetzung. Die hier versammelten Beiträge liefern wesentliche Anknüpfungspunkte, sowohl in Bezug auf das Selbstverständnis der TA und den eigenen Umgang mit Werten als auch in Bezug auf den Forschungsprozess und angemessene TA-Methoden.

\section{Ausblick}

Die normativen Bezüge der TA sind also vielschichtig. Dieser Befund steht in Gegensatz zur verbreiteten Annahme eines inhärenten ,normativen Defizits“ (Grunwald 1999) der TA, das vielfach Anlass zu Kritik gab. Insbesondere im Vergleich mit späteren Ansätzen wie Responsible Research and Innovation (RRI) wurde der TA zuweilen normative Blindheit vorgeworfen (van Lente et al. 2017) bzw. RRI als moralischer Gegenentwurf positioniert (Fisher 2017). Inzwischen liegt die ambivalente Position der TA zwischen Neutralitätsanspruch und normativen Bezügen offen und es werden unterschiedliche Ansätze des Umgangs damit vorgeschlagen. Die Verständigung über geteilte - auch theoriebasierte - Wertbezüge und daraus abzuleitende Verpflichtungen im Umgang mit gesellschaftlichen Problemen steht freilich noch am Anfang.

In der weiteren Auseinandersetzung um die Normativität in der TA sind (mindestens) zwei Dimensionen zu beachten: Einer- 
seits muss der TA-Prozess den Ansprüchen an die Wissenschaftlichkeit und die Ausgewogenheit der eingebrachten Perspektiven genügen. Das bedeutet, Fakten zusammen zu tragen und ihre Relevanz nach wissenschaftlichen Kriterien zu beurteilen, um Unterscheidungen zu treffen. Andererseits sind differente Interessen und Sichtweisen bzw. Weltanschauungen unterschiedlicher Akteure zu integrieren. TA liefert ja nicht nur konkrete Ergebnisse, sondern lässt sich als Teil eines (gesellschaftlichen) Bewusstwerdungsprozesses verstehen, in dessen Verlauf technische Zukünfte entworfen und alternative Lösungen definiert werden. Dabei erscheinen gewisse normative Setzungen unausweichlich. Diese zu verhandeln, anzupassen und Verfahren des reflexiven Umgangs damit zu entwickeln bleibt zentrale Herausforderung für die TA-Community.

\section{Literatur}

Bauer, Anja; Kastenhofer, Karen (2019): Policy advice in technology assessment. Shifting roles, principles and boundaries. In: Technological Forecasting and Social Change 139, S. 32-41.

Bimber, Bruce (1996): The politics of expertise in congress. The rise and fall of the Office of Technology Assessment. New York: State University of New York Press.

Böschen, Stefan; Dewald, Ulrich (2018): Theorie der Technikfolgenabschätzung reloaded. Ten years after. In: TATUP - Zeitschrift für Technikfolgenabschätzung in Theorie und Praxis 27 (1), S. 11-13. D0I: 10.14512/tatup.27.1.11.

Delvenne, Pierre; Parotte, Celine (2019): Breaking the myth of neutrality. Technology assessment has politics, technology assessment as politics. In: Technological Forecasting and Social Change 139, S. 64-72.

Dieckhoff, Christian (2015): Modellierte Zukunft. Energieszenarien in der wissenschaftlichen Politikberatung. Bielefeld: transcript.

Dobroć, Paulina; Krings, Bettina-Johanna; Schneider, Christoph; Wulf, Nele (2018): Alternativen als Programm. Plädoyer für einen Perspektivenwechsel in der Technikfolgenabschätzung. In: TATuP - Zeitschrift für Technikfolgenabschätzung in Theorie und Praxis 27 (1), S. 28-33. D0I: 10.14512/tatup.271.28. Dusseldorp, Marc (2014): Technikfolgenabschätzung zwischen Neutralität und Bewertung. In: APuZ 6-7, S. 25-30

Fisher, Eric (2017): Entangled futures and responsibilities in technology assessment. In: Journal of Responsible Innovation 4 (2), S. 83-84.

Ganzevles, Jürgen; van Est, Rinie; Nentwich, Michael (2014): Embracing variety. Introducing the inclusive modelling of (parliamentary) technology assessment. In: Journal of Responsible Innovation 1 (3), S. 292-313.

Grunwald, Armin (1999): Technology assessment or ethics of technology? Reflections on technology development between social sciences and philosophy. In: Ethical Perspectives 6 (2), S. 170-182.

Grunwald, Armin (2019): Technology assessment in practice and theory. New York: Routledge.

Hahn, Julia; Ladikas, Miltos; Scherz, Constanze (2018): Think global! Reflections on a global technology assessment. In: Michael Decker, Ralf Lindner, Stephan Lingner, Constanze Scherz und Mahshid Sotoudeh (Hg.): „Grand Challenges“ meistern. Der Beitrag der Technikfolgenabschätzung. Baden-Baden: Nomos, S. 41-49.

Hennen, Leonhard; Nierling, Linda (2015): Taking stock of TA in Europe and abroad. Introduction to the thematic focus. In: TATuP - Zeitschrift für Technikfolgenabschätzung in Theorie und Praxis 24 (1), S. 4-10.

Hennen, Leonhard; Nierling, Linda (2019): The politics of technology assessment. Introduction to the special issue. In: Technological Forecasting and Social Change 139, S. 17-22.

Nentwich, Michael (2016): Parliamentary technology assessment institutions and practices. A systematic comparison of 15 members of the EPTA network. ITA-manu:script 16-02. Vienna: ITA/OEAW.

Paschen, Herbert (1986): Technology Assessment. Ein strategisches Rahmenkonzept für die Bewertung von Technologien. Technik und Parlament. In: Meinolf Dierkes, Thomas Petermann und Volker von Thienen (Hg.) Technikfolgenabschätzung. Konzepte, Erfahrungen, Chancen. Berlin: edition sigma, S. 21-46.

Torgersen, Helge (2018): Die verborgene vierte Dimension. Normative Reflexion als Erweiterung der Theorie der Technikfolgenabschätzung. In: TATuP Zeitschrift für Technikfolgenabschätzung in Theorie und Praxis 27 (1), S. 21-27. DOI: 10.14512/tatup.27.1.21.

Torgersen, Helge (2019): Three myths of neutrality in TA. How different forms of TA imply different understandings of neutrality. In: Technological Forecasting and Social Change 139, S. 57-63.

van Lente, Harro; Swierstra, Tsalling; Joly, Pierre-Benoit (2017): Responsible innovation as a critique of technology assessment. In: Journal of Responsible Innovation 4 (2), S. 254-261.

Woesler, Christine; Lautmann, Robert (2011): „normativ“. In: Werner FuchsHeinritz et al. (Hg.): Lexikon zur Soziologie. Wiesbaden: VS Verlag für Sozialwissenschaften, S. 476.

Woopen, Christiane; Mertz, Marcel (2014): Ethik in der Technikfolgenabschätzung. In: APuZ 6-7, S. 40-46.
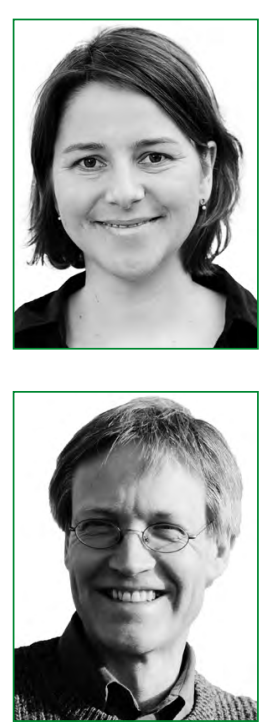

\section{DR. LINDA NIERLING}

arbeitet als Sozialwissenschaftlerin am Institut für Technikfolgenabschätzung und Systemanalyse (ITAS) des Karlsruher Instituts für Technologie (KIT). Ihre Arbeitsschwerpunkte umfassen die Digitalisierung der Arbeitswelt, soziale Aspekte von assistiven Technologien und Konzepte und Methoden von Technikfolgen.

\section{DR. HELGE TORGERSEN}

arbeitet seit 1990 am Institut für TechnikfolgenAbschätzung der Österreichischen Akademie der Wissenschaften, zuvor war er in der molekularbiologischen Forschung an der Universität Wien tätig. Hauptinteressen sind Biotechnologiepolitik, Risikoabschätzung, öffentliche Wahrnehmung und Kommunikation neuer Technologien. 


\title{
Implizite Wertbezüge in der Technikfolgenabschätzung
}

\author{
Plädoyer für eine Praxis der reflexiven Normativität
}

Regine Kollek, Universität Hamburg (kollek@uni-hamburg.de), (D) orcid.org/0000-0003-3607-1196

Im Hinblick auf ihre Ziele, ihre philosophischen Vorannahmen und methodischen Vorgehensweisen ist die Technikfolgenabschätzung (TA) wie andere Verfahren der systematischen Wissensproduktion auch durch normative Vorentscheidungen geprägt. Anders als die auf ihren Untersuchungsgegenstand bezogenen ethischen und gesellschaftlichen Aspekte werden diese nicht immer explizit thematisiert, was ein Problem hinsichtlich der Transparenz und Neutralität der TA aufwirft. Das hier vorgeschlagene Konzept der „reflexiven Normativität“ zielt darauf ab, die Wertbezüge der TA transparent zu machen und einseitige epistemisch-normative Selektivitäten zu vermeiden. Die dadurch ermöglichte Pluralität kann produktiv für die Weiterentwicklung der TA genutzt werden. Damit versteht sich das Konzept sowohl als Beitrag zur Theoriediskussion als auch zur Qualitätssicherung der TA.

\section{Implicit values in technology assessment}

A plea for reflexive normativity

In terms of its objectives, philosophical presuppositions, and methodological procedures, technology assessment (TA) is - like other methods of systematic knowledge production too - characterized by normative selectivities. In contrast to ethical and societal aspects related to its object of investigation, they are not always explicitly addressed. This poses a problem regarding the transparency and neutrality of TA. The concept of "reflexive normativity" proposed here aims at making the value relations of TA transparent and avoiding epistemic-normative selectivities. The resulting plurality can be utilized productively to further develop TA. Therefore, the concept proposed here is a contribution to both theory discussion and quality assurance of TA.

Keywords: technology assessment, values, epistemic neutrality, reflexive normativity

\section{Einleitung}

Bei der Folgenabschätzung und Bewertung von Technologien spielen neben ökologischen, sozialen, rechtlichen oder wirtschaftlichen Gesichtspunkten ethische und normative Fragen und Kriterien spätestens seit den 1990er-Jahren eine bedeutsame Rolle. Die Untersuchung ethischer, rechtlicher und sozialer Aspekte (im europäischen Kontext unter dem Akronym ELSA, im nordamerikanischen Kontext ELSI, für implications) ist heute Bestandteil nahezu aller nationalen und internationalen Forschungsförderungsprogramme. Über explizite, auf die Bewertung des Gegenstands einer Technikfolgenabschätzung (TA) bezogene ethisch-normative Fragen hinaus sind jedoch auch implizite Wertbezüge relevant. Diese prägen das zur Verfügung stehende bzw. in TA-Verfahren genutzte wissenschaftlich-technische Wissen ebenso wie die Technikfolgenabschätzung samt ihrer Prämissen, Konzepte, Ziele, Verfahrensweisen (Methoden) und Ergebnisse. $\mathrm{Zu}$ nennen sind hier beispielsweise die grundsätzliche Orientierung der TA an einer konsequentialistischen Ethik ${ }^{1}$, an Leitprinzipien wie Nachhaltigkeit und sozialer Gerechtigkeit, oder die Wahl bestimmter, z. B. partizipativer Verfahren. Solche Orientierungen und Verpflichtungen fordern als konstitutiver Bestandteil von TA-Prozessen das Postulat ihrer erkenntnistheoretischen (epistemischen) und methodischen Neutralität heraus. Denn zum einen führen sie dazu, dass die TA wie andere Verfahren der (wissenschaftlichen) Erkenntnisproduktion auch - bestimmten, normativ geprägten Selektivitäten nicht entkommen kann (Skorupinski und Ott 2002). Zum anderen stellen sie die verbreitete Annahme einer Differenz zwischen Fakten und Normen infrage.

Die Probleme und Herausforderungen, die im Spannungsfeld zwischen einer (politisch) geforderten und teilweise auch beanspruchten Neutralität und einem epistemischen und durch (politische) Zielsetzungen gegebenen Wertbezug auftreten können, begleiten die TA von Anfang an. Sie waren und sind Gegen-

1 Konsequentialistische Ethiktheorien beurteilen den moralischen Wert einer Handlung aufgrund ihrer Konsequenzen. Über konsequentialistische Ansätze hinaus spielen in bestimmten Fällen auch deontologische, also pflichtethische Theorien eine Rolle. 
stand theoretischer Debatten und kritischer Reflexionen von TA. Daran knüpft dieser Artikel an, der unter Bezug auf neuere Entwicklungen in der Wissenschafts- und Technikforschung die Annahme einer epistemischen Neutralität der TA dekonstruiert. Den daraus resultierenden Problemen und (scheinbaren) Ausweglosigkeiten werden ein Konzept und Vorschläge für eine Praxis der „reflexiven Normativität“ entgegengestellt, die nicht nur die normative Prägung der TA zur Kenntnis nehmen, sondern gleichzeitig Wege für die Entwicklung neuer Zugänge zum Umgang mit normativen Prämissen und Prägungen eröffnen.

\section{Verhältnis von TA und Normativität}

Werte und Normen sind bei der Erzeugung von Wissen nicht wegzudenken; sie sind untrennbar mit den jeweiligen Prämissen, Konzepten, Verfahren und Zielen der Wissensproduktion verbunden. Dies gilt sowohl für Wissenschaft und Technik als auch für die TA. Innerhalb der TA wird das daraus folgende Problem der Nicht-Trennbarkeit von Fakten und Normen seit etwa Mitte der 1980er-Jahre thematisiert. TA wurde als „,wertsensibles Verfahren“ eingeschätzt (Enquetekommission Technikfolgen-Abschätzung 1986), bei dem Interessen und Normen eine entscheidende Rolle spielen. Annahmen und Werturteile sowie deren Begründung müssen deshalb offengelegt und TA in jedem Schritt transparent und nachprüfbar gestaltet werden ( $\mathrm{Pa}$ schen und Petermann 1992). Dies betrifft sowohl die Aussagen und Überlegungen, die sich auf den Gegenstand der TA bzw. das zu untersuchende wissenschaftlich-technische System und seine möglichen Implikationen beziehen, als auch den TA Prozess selber. Weitere wichtige Diskussionsstränge in diesem Zusammenhängen waren und sind u. a. die Objektivität bzw. Neutralität in der parlamentarischen TA in der Praxis umzusetzen (Grunwald 2003), existiert jedoch innerhalb der TA Community kein gemeinsames Grundverständnis hinsichtlich der Konzepte und Methoden, wie dieses geschehen kann.

Befördert wurde diese Entwicklung vor allem durch die konstruktivistische ${ }^{2}$ Wende in der Wissenschafts- und Technikforschung, mit der die soziale Konstruiertheit wissenschaftlicher Fakten und Erkenntnisse in den Vordergrund tritt. Dadurch erweist sich Wissenschaft als unentwirrbar verwoben mit politischen und gesellschaftlichen Ideen und Werten. Infolgedessen wird die Trennung zwischen Fakten und Werten bzw. Normen in den Science and Technology Studies (STS), die die TA heute stark beeinflussen, insgesamt abgelehnt (Fuller 2006; Jasanoff et al. 2001). Auch die TA selber blieb von diesen Entwicklungen nicht verschont; normative Elemente und Vorentscheidungen lassen sich auf allen Ebenen von TA-Prozessen identifizieren. Das fängt bei der Wahl des ethisch-philosophischen Grundkonzeptes an, reicht über die Selektion der zu evaluierenden Technologie, der relevanten Schutzziele, der zu analysierenden Folgedimensionen oder Endpunkte, der Methoden und Modelle, der involvierten Akteure bis hin zur Art und Weise wie die Resultate präsentiert werden und so weiter. Auch in die Analyse und Synthese von Evidenz gehen Werturteile ein (Strech und Tilbur 2008; Kollek 2013). Damit erschüttert der Sozialkonstruktivismus den Anspruch auf Neutralität in der TA, also eines ihrer drei Fundamente neben Rationalität und Inklusivität (Torgersen 2019). Denn wie soll man zu einem neutralen Urteil über das, was Sache ist, kommen, wenn jede Tatsache zugleich Wert und jeder Wert konstruiert, also „Tatsache“ ist (Hofmann et al. 2018)? In anderen Worten: ,where the factual and the normative collapse, neutrality cannot be secured anymore“ (Torgersen 2019, S. 61).

\section{Durch „reflexive Normativität“ werden die der Forschung zugrundeliegenden Wertsysteme zum Objekt der Reflexion.}

des Expertenwissens angesichts des Wertbezugs jeglichen (wissenschaftlichen) Wissens und die damit zusammenhängende Untrennbarkeit von Fakten und Normen (Harding 1986; Longino 1990), die Überwindung oder Neutralisierung des selektiven Wertbezugs durch die Beteiligung von Laien bzw. Stakeholdern in partizipatorischen TA-Modellen (Hennen 2003), oder die Systematisierung der sehr unterschiedlichen Wertbezüge, die im Zusammenhang mit TA-Prozessen relevant sind (Palm und Hansson 2006; Stilgo et al. 2013). Vergleichbare Diskussionen fanden und finden ebenfalls in spezialisierten TA-Feldern wie beispielsweise dem Health Technology Assessment (HTA) statt (Heitmann 1998). Letztlich lautet die Frage seit geraumer Zeit nicht mehr $o b$ sich die TA mit ihren (impliziten) normativen Fragen beschäftigen muss, sondern vor allem wie dies getan werden kann. Trotz vorhandener Ansätze, dieses Desiderat vor allem
Die sozialkonstruktivistische Relativierung der Differenz von Fakten und Werten führt also in eine (scheinbare) Ausweglosigkeit, die u. a. ein Einfallstor für Zweifel an der Möglichkeit der Gewinnung zuverlässiger Informationen über die Implikationen technologischer Entwicklungen für politische Entscheidungen bildet. Parallel dazu wächst jedoch der gesellschaftliche Bedarf an der Evaluation technologischer sowie soziotechnischer Entwicklungen. Damit steht die TA heute vor neuen theoretischen und praktischen Herausforderungen, bei denen es nicht nur da-

2 Konstruktivismus bzw. die konstruktivistische Erkenntnistheorie ist eine Strömung in der Wissenschaftsphilosophie. Danach ist wissenschaftliches Wissen durch die wissenschaftlichen Communities konstruiert. In die jeweiligen Modelle oder Konzeptualisierungen der untersuchten Phänomene gehen nicht nur Daten und Messwerte, sondern auch sozial bedingte Faktoren wie beispielsweise theoretische Vorannahmen, Präferenzen und Relevanzkriterien ein. 
rum geht, der genannten Relativierung ihre destruktive Wirkung zu nehmen, sondern auch darum, theoretisch informierte, pragmatische Ansätze zu ihrer praktischen Bewältigung zu entwickeln.

\section{Von impliziter zu reflexiver Normativität}

Die Erkenntnis, dass wissenschaftliches Wissen durch interne wie externe Werte und Normen geprägt ist, führt allerdings in der Regel nicht dazu, dass der praktische Nutzen von Erkenntnissen in Zweifel gezogen wird. Dies ist auch weder sinnvoll noch hilfreich, denn alternative Wissenskonzepte sind mit dem gleichen Problem konfrontiert bzw. verstärken es teilweise sogar. Ein Ausweg besteht zum einen darin, die Normativität von Wissen und von in TA-Prozessen gewonnen Erkenntnissen transparent zu machen. Zum anderen geht es darum, diese intrinsische Normativität produktiv für eine erweiterte Inklusion von Positionen und Sichtweisen in der TA und somit letztlich auch für die Steigerung ihrer prozeduralen Neutralität zu nutzen. Die Dekonstruktion des Postulats epistemischer Neutralität eröffnet somit die Chance, neue Konzepte zu entwickeln, die es der TA (und der Wissenschaft generell) erlauben, ihre Funktion in der wissenschaftlichen Politik- und Gesellschaftsberatung zu erfüllen, ohne dass ihre normativen Prägungen im Dunkeln bleiben oder nur bestimmte Wissenstypen präferiert werden.

Vorgeschlagen wird hier dafür das Konzept einer ,reflexiven Normativität“". Gemeint ist damit die (teilweise bereits existierende) bewusste und systematische Etablierung reflexiver Prozesse in der TA als Projekt und als Institution, die darauf abzielen, Werte und normative Vorentscheidungen der Akteure nicht nur transparent zu machen, sondern sie auch bewusst für einen Ausgleich einseitiger und parteilicher Selektionen zugunsten einer größeren Pluralität und Inklusivität in TA-Verfahren zu nutzen. Das hier vorgestellte Konzept ist eines des second order learnings, bei dem die der Forschung zugrundeliegenden Wertsysteme zum Objekt der Reflexion werden (Schot und Rip 1997; Schuurbiers 2011). Reflexive Normativität geht aber insofern darüber hinaus, als sie nicht nur auf Bewusstseins- und Lernprozesse der Forscher ${ }^{3}$ abzielt, sondern als konstitutive Eigenschaft von über sich selbst aufgeklärten TA-Akteuren und -Institutionen konzeptualisiert wird.

Das Konzept der Reflexivität ist in Soziologie, Pädagogik oder Kulturwissenschaften etabliert; gleichwohl existieren zahlreiche unterschiedliche Ansätze (Lynch 2000). Ohne im Einzelnen darauf eingehen zu können, ist die hier vorgeschlagene Reflexivität weder als individuelle Introspektion, noch allein als Reflexion externer sozialer Werte einer TA zu verstehen. Vielmehr geht es um eine Identifikation und Offenlegung normativer Prämissen auf allen Ebenen der TA. Das Ziel ist nicht, impli-

3 Aus Gründen der Lesbarkeit wird hier die männliche Form verwendet. Explizit sind damit jeweils die weiblichen und männlichen Angehörigen der genannten Gruppe gemeint. zite oder auch explizite normative Vorannahmen zu vermeiden was ohnehin kaum möglich ist - sondern sie zu identifizieren, sie argumentativ zu begründen und so die Verantwortung dafür zu übernehmen. Insofern ist reflexive Normativität nicht nur eine grundlegende Voraussetzung für ein besseres Verständnis der Neutralität der TA, sondern auch für die Erhöhung ihrer Glaubwürdigkeit (Torgersen 2019). Als institutionalisierte Praxis trägt sie nicht nur dazu bei, die Qualität von TA-Prozessen zu verbessern, sondern macht ihre Ergebnisse auch transparenter. So kann aus einer impliziten eine ,reflexive“ Normativität werden, die den konstitutiven Bezug der TA zum Normativen nicht leugnet, ihn aber bewusst und reflexiv für eine diskursive Verhandlung öffnet.

\section{Ansätze reflexiver Normativität}

Ansätze für die Etablierung einer reflexiven Normativität finden sich in unterschiedlichen Bereichen, insbesondere im HTA, in den STS und in der qualitativen Sozialforschung. Im HTA, dem es um die Untersuchung von Möglichkeiten, Risiken und Implikationen (bio-)medizinischer Technologien und deren Bewertung geht, bemüht man sich seit geraumer Zeit darum, ethisch-normative Aspekte systematisch zu integrieren (Heitmann 1998; Kollek 2004; Burls et al. 2011; Bellamare et al. 2018). Trotz zahlreicher Beiträge existiert z.Zt. jedoch noch kein gemeinsames Verständnis von der generellen Aufgabenstellung und Ausgestaltung eines solchen Konzeptes. Eine Übersichtsarbeit von 2014 identifizierte in der Literatur 43 Vorschläge und praktische Richtlinien dafür; diese variieren jedoch hinsichtlich ihres philosophischen Zugangs, ihrer Struktur und Reichweite erheblich (Assasi et al. 2014). Ein kürzlich erschienener systematischer Überblick kam nach Analyse von 67 nach einschlägigen Kriterien ausgewählten Publikationen zu dem Schluss, dass es weder etablierte Verfahren für die Integration ethisch-normativer Aspekte in das HTA noch einen Konsensus über die Rolle von Ethiktheorien oder ethischer Expertise in diesem Zusammenhang gibt, was die systematische Integration solcher Aspekte in HTA-Verfahren oder Berichten behindert (Bellemare et al. 2018).

Eines der entscheidenden Probleme besteht darin, dass der Begriff der ethisch-normativen Aspekte ein sehr heterogenes Spektrum an Themen und Fragen umfasst, die auch noch unterschiedlichen analytischen Kategorien zuzurechnen sind, so dass sie sich nur schwer systematisieren lassen. Bellemare et al. (2018) identifizierten als relativ plausiblen gemeinsamen Nenner für die verschiedenen Kategorien den Begriff des ,Werturteils“. Mit seiner Hilfe könnten Wertbezüge sichtbar gemacht und damit zum Bestandteil eines reflexiven Prozesses werden. Vielversprechend sind hier wertphilosophische Ansätze, die darauf abzielen, offensichtliche und verborgene Wertfragen durch eine (unvollständige) Auswahl gezielter Fragen herauszuarbeiten, um auf diese Weise ethische Reflexionen auszulösen (Hofmann 2005). Die Nutzung solcher Ansätze wurde im HTA bereits produktiv erprobt (Burls et al. 2011). 
Hinweise und Ansatzpunkte zum Weiterdenken finden sich auch im Bereich der STS (Woolgar 1988; Wynne 1995; Lynch 2000) und der TA (Swierstra und Rip 2007; Grunwald 2004; Torgersen 2019). Diskutiert wird die Notwendigkeit einer Reflexivität darüber hinaus auch in der Technik- und Innovationsforschung, die sich aktuell um eine inhaltliche Präzisierung des Begriffs des Responsible Research and Innovation“ (RRI) bemüht (Schomberg 2011; Grunwald 2014). Hier gilt Reflexivität (neben anticipation, inclusion und responsiveness) als eine von vier Dimensionen verantwortlicher Forschung und Innovation (Stilgoe et al. 2013). Trotz des Bedarfs und Interesses daran ist eine solche Reflexivität nicht leicht als Standard in TA-Verfahren zu etablieren. Dies liegt möglicherweise nicht nur an der He- gelt es an theoretischen und methodischen Instrumenten, mit deren Hilfe sich Reflexivität operationalisieren lässt (Mauthner und Doucet 2003, S. 414). Auch in der TA existieren dafür bisher nur wenige systematisch ausgearbeitete Vorschläge. Stilgoe et al. (2013) nennen beispielsweise codes of conduct oder die Einführung von Standards, welche Verbindungen zwischen externen Wertsystemen und der wissenschaftlichen Praxis herstellen. Auch wird versucht, Reflexivität dadurch zu fördern, dass beispielsweise Naturwissenschaftler mit Sozial- und Geisteswissenschaftlern schon bei der Entwicklung von Wissenschaft und Technik miteinander kommunizieren. Im Socio-Technical Integration Research ${ }^{4}$ (Fisher et al. 2015) werden Angehörige solcher Disziplinen teilweise bereits im Labor mit einbezogen, um

\section{In der Praxis bedeutet „reflexive Normativität“ einen kontinuierlichen, das gesamte Projekt begleitenden reflexiven Prozess.}

terogenität ethisch-normativer Aspekte und am Fehlen etablierter Verfahren für ihre systematische Integration wie weiter oben für das HTA beschrieben, sondern u. U. auch an der teilweise immer noch vorhandenen Vorstellung der Wertfreiheit der Wissenschaft und der moralischen Arbeitsteilung zwischen Wissenschaft und Innovation (Swierstra und Rip 2007).

In der qualitativen Sozialforschung (Soziologie, Ethnographie, Anthropologie, Psychologie etc.) gehört Reflexivität zu den fundamentalen Voraussetzungen der Arbeit (Mauthner und Doucet 2003; Lazard und McAvoy 2017). Ausgangspunkt ist das konstruktivistische Wissenschaftsparadigma und die Feststellung, dass der soziale und politische Ort der Forschenden die Forschung und ihre Ergebnisse beeinflusst. Hier stellt sich die Frage, was die Wissenschaftler selber in die empirische Forschung bzw. die Beobachtung und ihre Interpretation mit einbringen (Koch und Harrington 1998). Neben subjektiven Elementen sind das in erster Linie die jeweils relevanten Prämissen über Forschungsgegenstand, Fragestellung, Theorien, Methoden, Ergebnispräsentationen etc., aber auch die Einflüsse des sozialen, politischen und historischen Kontexts, in dem die Forschung stattfindet (Doucet und Mauthner 2006), der Geltungsbereich und die Grenzen des produzierten Wissens (Lazard und McAvoy 2017, S.9) sowie der Einfluss von Werten und Vorannahmen auf die Interpretation von Forschungsergebnissen, die regelhaft in einer komplexen Matrix alternativer Repräsentationen existieren (Marcus 1994, S. 571).

\section{Elemente und Praxen reflexiver Normativität}

Obwohl die Bedeutung der Reflexivität in der Sozialforschung etabliert ist, werden die Möglichkeiten und Verfahren ihrer praktischen Umsetzung eher selten adressiert; nach wie vor man- soziale Normen und Werte zu adressieren, die üblicherweise erst downstream, also später bei der politischen Regulierung zur Sprache kommen (Fisher und Rip 2013). Normative Ideale oder Zukunftsvisionen, die wissenschaftliche Forschungsagenden vorantreiben, sollen so offengelegt und thematisiert werden, um die Reflexion von Laborwissenschaftlern über den sozio-ethischen Kontext ihrer Arbeit zu unterstützen (Schuurbiers 2011). Um Innovationstrajektorien im Sinne der Förderung des Gemeinwohls zu verändern, wird jedoch darüber hinaus auch der Einschluss weiterer Akteure aus dem Bereich der Governance (Forschungsförderung, Regulierung etc.) für nötig gehalten (Wynne 2011).

Interessante Hinweise zur Operationalisierung reflexiver Normativität, die auch für die TA fruchtbar gemacht werden könnten, finden sich im Kontext der qualitativen Sozialforschung, wo Reflexivität hinsichtlich der eigenen Prämissen und Methoden normalerweise als Instrument zur Verbesserung der Forschung und der Ergebnisqualität gilt (Koch und Harrington 1998; Guillemin und Gillam 2004). Sozialwissenschaftliche Untersuchungen, die sich einem doing reflexivity widmen, gehen praktisch ausnahmslos davon aus, dass es sich dabei nicht um eine singuläre Aktivität, sondern um einen kontinuierlichen, das gesamte Projekt begleitenden reflexiven Prozess handeln sollte (Guillemin und Gillam 2004, S. 274), der die Frage nach dem what is going on in der Forschung beantwortet. Um zu verfolgen und zu dokumentieren, was im Laufe eines Forschungsprojekts geschieht, wird die Führung eines „Reflexiven Journals“, also eines Forschungstagebuchs vorgeschlagen, in dem in epistemischer und normativer Hinsicht relevante Fragen notiert und kritisch reflektiert werden (Koch und Harrington 1998). Als weitere reflexivitätsfördernde Aktivitäten werden die Analyse des Forschungskontexts oder die Hinzuziehung von Supervisoren genannt, die die Vorannahmen des Projekts kritisch befragen.

4 Siehe http://cns.asu.edu/stir, zuletzt geprüft am 07.02.2019. 
Angeregt wird auch, eine reflexive Darstellung in den Projektbericht zu integrieren, um Teilnehmern und Entscheidungsträgern dessen Verlauf und die dabei gefällten Selektionen und Entscheidungen transparent zu machen (Jootun et al. 2013).

Diese Vorschläge machen über die bereits existierende Praxis hinaus weitere Konturen und Elemente von doing reflexivity im Kontext der TA sichtbar. Zu den relativ gut umsetzbaren gehört die Entwicklung von codes of conduct bzw. die Einführung von Praxisregeln oder Standards, mit deren Hilfe Reflexivität operationalisiert und die Verbindungen zwischen externen Wertsystemen und TA-Praxis hergestellt werden können. Die vorgeschlagenen „Reflexiven Journale“ können ein hilfreicher Ausgangspunkt dafür sein. Die Integration von Sozial- oder Geisteswissenschaftlern in den wissenschaftlich-technischen Entwicklungsprozess selber wäre vermutlich sinnvoll; die Realisierung dieses Desiderats hängt jedoch unmittelbar mit dem Zeitrahmen und der finanziellen Ausstattung solcher Projekte zusammen. Unabhängig davon bietet sich jedoch an, die in partizipativen oder anderen TA-Verfahren involvierten Teilnehmer bzw. Stakeholder in reflexive Prozesse einzubeziehen.

\section{Fazit}

Die Dekonstruktion der Neutralität und die Analyse ihrer impliziten Normativität stellt die TA vor erhebliche Herausforderungen, die zwar seit langem diskutiert werden, deren praktische Bewältigung jedoch erst in Ansätzen gelungen ist. Da gleichzeitig der gesellschaftliche Bedarf an zuverlässigen Informationen über die möglichen Implikationen technologischer Entwicklungen steigt, muss die TA neue, theoretisch informierte und pragmatisch umsetzbare Ansätze zur Reflexion ihrer eigenen, zumeist impliziten normativen Voraussetzungen und für deren Transparenz entwickeln, denn nur so haben die Teilnehmer an TA-Prozessen die Möglichkeit, deren Relevanz für die Ergebnisse eines TA Prozesses und die Formulierung von Empfehlungen einzuschätzen. Die Etablierung und Institutionalisierung des hier vorgestellten Konzepts der reflexiven Normativität sowie seine zukünftige Weiterentwicklung können ein Beitrag dazu sein.

Das Konzept zielt darauf ab, die in der TA - wie in der Wissenschaft generell - intrinsische Normativität von Zielen, Theorien, Methoden, Verfahren und Erkenntnissen produktiv zu nutzen. Dies kann a) durch eine systematische, methodengeleitete Analyse des Wertbezugs und anschließend daran b) durch eine Praxis des doing reflexivity mit den beschriebenen und weiter zu entwickelnden Elementen geschehen.

Dadurch besteht zum einen die Chance, epistemisch-normative Engführungen und vorgängige Selektivitäten in TA-Prozessen transparent zu machen und sie zugunsten einer größeren Pluralität zu reduzieren. Insofern ist reflexive Normativität auch eine Strategie für den Umgang mit den epistemisch-normativen Unsicherheiten, mit denen zahlreiche Ansätze zur Bewältigung komplexer Problemlagen konfrontiert sind. Zweitens kann eine in TA-Projekten und Institutionen etablierte reflexive Normativität dazu beitragen, den Vorwurf der normativen Voreingenommenheit abzuwehren, die Glaubwürdigkeit der TA zu erhöhen und so ihre Funktion und Akzeptanz in Gesellschaft und Politikberatung zu stabilisieren. Insofern ist die formale Etablierung reflexiver Normativität auch als Instrument der Qualitätssicherung von TA-Verfahren zu verstehen.

\section{Literatur}

Assasi, Nazila; Schwartz, Lisa; Tarride, Jean-Eric; Campbell, Kaitryn; Goeree, Ron (2014): Methodological guidance documents for evaluation of ethical considerations in health technology assessment. A systematic review. In: Expert Review of Pharmacoeconomics \& Outcomes Research 14 (2), S. 203-220. Bellemare, Christian et al. (2018): Ethics in health technology assessment. A systematic review. In: International Journal of Technology Assessment in Health Care 34 (5), S. 1-11.

Burls, Amanda et al. (2011): Tackling ethical issues in health technology assessment. A proposed framework. In: International Journal of Technology Assessment in Health Care 27 (3), S. 230-237.

Doucet, Andrea; Mauthner, Natasha (2006): Feminist methodologies and epistemology. In: Clifton Bryant und Dennis Peck (Hg.): 215t century sociology. A reference handbook. Thousand Oaks, CA: Sage, S. 36-45.

Enquete-Kommission Technikfolgen-Abschätzung (1986): Enquete-Kommission „Einschätzung und Bewertung von Technikfolgen; Gestaltung von Rahmenbedingungen der technischen Entwicklung ". Zur Institutionalisierung einer Beratungskapazität für Technikfolgen-Abschätzung und -Bewertung beim Deutschen Bundestag, BT Drs. 10/5844.

Fisher, Eric; Rip, Arie (2013): Responsible innovation. Multi-Level dynamics and soft intervention practices. In: Richard Owen, John Bessant und Maggy Heintz (Hg.): Responsible innovation. Managing the responsible emergence of science and innovation in society. New York: John Wiley \& Sons, S. 165-183.

Fisher, Eric et al. (2015): Mapping the integrative field. Taking stock of sociotechnical collaborations. In: Journal of Responsible Innovation 2 (1), S. 39-61.

Fuller, Steve (2006): The philosophy of science and technology studies. New York: Routledge.

Grunwald, Armin (2003): Technology assessment at the German Bundestag. 'Expertising' democracy for 'democratising' expertise. In: Science and Public Policy 30 (3), S. 193-198.

Grunwald, Armin (2004): Strategic knowledge for sustainable development. The need for reflexivity and learning at the interface between science and society. In: International Journal of Foresight and Innovation Policy 1 (1-2), S. 150-167.

Grunwald, Armin (2014): Technology assessment for responsible innovation. In: Responsible Innovation 1, pp. 15-31.

Guillemin, Marilys; Gillam, Linn (2004): Ethics, reflexivity, and 'ethically important moments' in research. In: Qualitative Inquiry 10 (2), S.261-280.

Harding, Sandra (1986): The science question in feminism. Ithaca, NY: Cornell University Press.

Heitman, Elisabeth (1998): Ethical issues in technology assessment. Conceptual categories and procedural considerations. In: International Journal of Technology Assessment in Health Care 14 (3), S. 544-566.

Hennen, Leonhard (2003): Experten und Laien. Bürgerbeteiligung und Technikfolgenabschätzung in Deutschland. In: Bürgerkonferenz. Streitfall Gendiagnostik. Wiesbaden: VS Verlag für Sozialwissenschaften, S. 37-47. 
Hofmann, Bjørn (2005): Toward a procedure for integrating moral issues in health technology assessment. In: International Journal of Technology Assessment in Health Care 21 (3), S. 312-318.

Hofmann, Bjørn; Bond, Ken; Sandman, Lars (2018): Evaluating facts and facting evaluations. On the fact-value relationship in HTA. In: Journal of Evaluation in Clinical Practice 24, S. 957-965.

Jasanoff, Sheila; Markle, Gerald; Peterson, James; Pinch, Trevor (Hg.) (2001): Handbook of science and technology studies. Thousand Oaks, CA: Sage.

Jootun, Dev; McGhee, Gerry; Marland, Glenn (2009): Reflexivity. Promoting rigour in qualitative research. In: Nursing Standard 23 (23), S. 42-46.

Koch, Tina; Harrington, Ann (1998): Reconceptualizing rigour. The case for reflexivity. In: Journal of Advanced Nursing 28 (4), S. 882-890.

Kollek, Regine (2004): BioMedical Technology Assessment. Modulare Folgenerfassung und perspektivensensitive Bewertung biomedizinischer Innovationen. In: TATuP - Zeitschrift für Technikfolgenabschätzung in Theorie und Praxis 13 (3), S. 85-88.

Kollek, Regine (2013): Ethik der Technikfolgenabschätzung in Medizin und Gesundheitswesen. Herausforderungen für Theorie und Praxis. In: Alexander Bogner (Hg.): Ethisierung der Technik. Technisierung der Ethik. Baden-Baden: Nomos, S. 199-214.

Lazard, Lisa; McAvoy, Jean (2017): Doing reflexivity in psychological research. What's the point? What's the practice?. In: Qualitative Research in Psychology, S.1-19.

Longino, Helen (1990): Science as social knowledge. Values and objectivity in scientific inquiry. Princeton: Princeton University Press.

Lynch, Michael (2000): Against reflexivity as an academic virtue and source of privileged knowledge. In: Theory, Culture \& Society 17 (3), S. 26-54.

Marcus, George (1994): What comes (just) after "post"? The case of ethnography. In: Norman Denzin und Yvonna Lincoln ( $\mathrm{Hg}$.): Handbook of qualitative research. Thousand Oaks, CA: Sage, S. 563-574.

Mauthner, Natasha; Doucet, Andrea (2003): Reflexive accounts and accounts of reflexivity in qualitative data analysis. In: Sociology 37 (3), S. 413-431.

Palm, Elin; Hansson, Sven (2006): The case for ethical technology assessment (eTA). In: Technological Forecasting and Social Change 73 (5), S. 543-558.

Paschen, Herbert; Petermann, Thomas (1992): Technikfolgen-Abschätzung. Ein strategisches Rahmenkonzept für die Analyse und Bewertung von Techniken. In: Thomas Petermann (Hg.): Technikfolgen-Abschätzung als Technikforschung und Politikberatung. (Veröffentlichungen der Abteilung für Angewandte Systemanalyse (AFAS), Bd. 1). Frankfurt am Main: Campus, S. 19-42.

Schomberg, René von (2011): Prospects for technology assessment in a framework of responsible research and innovation. In: Marc Dusseldorp und Richard Beecroft (Hg.): Technikfolgen abschätzen lehren. Bildungspotenziale transdisziplinärer Methoden. Wiesbaden: VS Verlag für Sozialwissenschaften, S. 39-61.

Schot, Johan; Rip, Arie (1997): The past and future of constructive technology assessment. In: Technological Forecasting and Social Change 54 (2-3), S. 251-268.

Schuurbiers, Daan (2011): What happens in the lab. Applying midstream modulation to enhance critical reflection in the laboratory. In: Science and Engineering Ethics 17 (4), S.769-788.

Skorupinski, Barbara; Ott, Konrad (2002): Technology assessment and ethics. In: Poiesis \& Praxis 1 (2), S. 95-122.
Stilgoe, Jack; Owen, Richard; Macnaghten, Phil (2013): Developing a framework for responsible innovation. In: Research Policy 42 (9), S. 1568-1580.

Strech, Daniel; Tilburt, Jon (2008): Value judgments in the analysis and synthesis of evidence. In: Journal of Clinical Epidemiology 61 (6), S. 521-524.

Swierstra, Tsjalling; Rip, Arie (2007): Nano-ethics as NEST-ethics. Patterns of moral argumentation about new and emerging science and technology. In: NanoEthics 1 (1), S. 3-20.

Torgersen, Helge (2019): Three myths of neutrality in TA. How different forms of

TA imply different understandings of neutrality. In: Technological Forecasting and Social Change 139, S. 57-63.

Woolgar, Steve (Hg.) (1988): Knowledge and reflexivity. New frontiers in the sociology of knowledge. London: Sage.

Wynne, Brian (1995): Technology assessment and reflexive social learning. Observations from the risk field. In: Thomas Misa, Arie Rip und Johan Schot $(\mathrm{Hg})$ : Managing technology in society. The approach of constructive technology assessment. London: Pinter Publishers, S. 19-36.

Wynne, Brian (2011): Lab work goes social, and vice versa. Strategising public engagement processes. In: Science and Engineering Ethics 17 (4), S. 791-800.

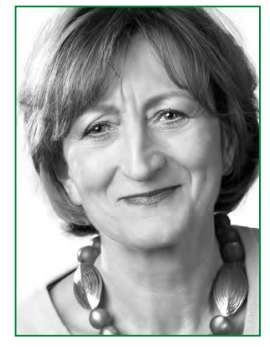

PROF.DR. REGINE KOLLEK

ist Professorin für Technikfolgenabschätzung der modernen Biotechnologie in der Medizin und war bis 2016 geschäftsführende Direktorin des FSP Biotechnik, Gesellschaft und Umwelt der Universität Hamburg. Ihre Forschungsschwerpunkte sind neben der Technikfolgenabschätzung epistemische und ethische Fragen moderner lebenswissenschaftlicher Entwicklungen. 


\title{
Making the invisible visible
}

\author{
Normativities in and of technology assessment
}

\author{
Federica Lucivero, Ethox Centre and Wellcome Centre for Ethics and Humanities, Nuffield Department of Population Health, University of Oxford, \\ Old Road campus, Oxford (federicalucivero@ethox.ox.ac.uk), (1) orcid.org/0000-0002-1308-5846 \\ Pierre Delvenne, University of Liège, SPIRAL Research Centre (pierre.delvenne@uliege.be) \\ Michiel van Oudheusden, Belgian Nuclear Research Centre (mvoudheu@sckcen.be), (1) orcid.org/0000-0003-3748-0469
}

Technology assessment (TA) is an analytic and interactive practice that produces evaluative judgments about the societal implications of technology. Despite this distinct evaluative disposition, "normativities" inherent in TA programs and practices often remain hidden. Therefore, TA practice and outcomes often overlook a range of methodological, ethical, and political issues. In an attempt to remedy this shortcoming, this article explores how TA aims to improve political decision making in science and technology (meta-normativity) and is imbued with the values, norms, and moral positions of both participants and TA practitioners (in-normativity). It provides recommendations to render these normativities in TA more visible, and thereby amenable to reconsideration and change.

\section{Das Unsichtbare sichtbar machen}

Normativitäten in und von Technikfolgenabschätzung

Die Technikfolgenabschätzung (TA) ist eine analytische und interaktive Methode zur wertenden Beurteilung der gesellschaftlichen Auswirkungen von Technik. Trotz dieser klar wertenden Ausrichtung bleiben die TA-Programmen und -Methoden inhärenten „Normativitäten " oft im Verborgenen. Somit werden in der TA-Praxis und ihren Ergebnissen oft eine Reihe von methodischen, ethischen und politischen Aspekten nicht berücksichtigt. Um hier Abhilfe zu schaffen, untersucht der vorliegende Artikel, auf welche Weise TA die politische Entscheidungsfindung in Wissenschaft und Technik verbessern will (Meta-Normativität) und wie sie von den Werten, Normen und moralischen Standpunkten von Teilnehmern und TA-Praktikern geprägt ist (In-Normativität). Er gibt Empfehlungen, wie die der TA inhärenten Normativitäten sichtbar und damit offen für neue Erwägungen und Veränderung gemacht werden können.

Keywords: deliberation, ethics, normativity, pragmatism, technology assessment

This is an article distributed under the terms of the Creative Commons Attribution License CCBY 4.0 (https://creativecommons.org/licenses/by/4.0/)

https://doi.org/10.14512/tatup.28.1.21

Submitted: 24.10.2018. Peer reviewed. Accepted: 13.02.2019

\section{Introduction}

Since the 1960s, technology assessment (TA) approaches have emerged that seek to facilitate interactions between technological experts, citizens, civil society organizations, and other relevant social groups, to enable the collective management of technology. Utilizing a range of participatory methods and techniques, TA engages these parties to deliberate towards socially robust decision outcomes and incite social learning among them. As TA seeks to be of "service to policy making and decision making more generally" (Rip 2015, p. 125), TA is normative in character. The rationale behind TA programs and processes is not just to describe the potential social implications of technologies, but also to evaluate whether these implications are good or bad (or mixed) for society. We can consider an evaluation as 'normative' if a technology is assessed with respect to an explicit legal or moral norm or an authoritative standard. In general terms, if the goal of TA is to facilitate the development of "better technologies in better societies" (Schot and Rip 1997, p. 256), then we may ask what is better, for whom, and why, in order to understand what TA promises and how TA contributes to science and society at large.

TA is more than an analytic activity aimed at providing decision makers with an objective analysis of a technology (van Eijndhoven 1997), and more than interactive and communicative tool that aims to enrich the basis for science and technology decision making (Decker and Ladikas 2004). Both conceptually and through its modes of operation, TA hints at a more inclusive and equitable science-society relationship than is presently the case. In addition, several contemporary TA approaches rest on a vision of democracy as a deliberative, cooperative and consensual way of dealing with social conflicts, and the conviction that social learning is morally superior to political bargaining (Abels 2007). TA therefore holds a normative and political orientation, as it invokes standards and moral principles to legitimize its procedures and guide them. Furthermore, the products of TA activities (be they recommendations, policy reports or guidelines) appeal to moral principles that the involved actors should follow, distribute roles and responsibilities among them, and favour particular solutions over others. We are hence led to 
question the meaning and implications of what is taken as good or bad technology development and assessment.

This normative character of TA is not often acknowledged by practitioners. In an article supporting the collaboration between the fields of ethics and TA, Grunwald (1999) argues that TA may be seen to suffer from 'normative deficits' (ibid., p. 174) as it does not directly engage with its evaluative goal and practice. Although several authors point out that TA has to tackle normative questions only few scholars have engaged with these questions (Grunwald 2004; Palm and Hanson 2006; Brey 2012; Lucivero et al. 2011; Lucivero 2016; Kiran et al. 2015).
When TA emerged, it was a practicable response to real-world challenges that are hard to control, such as sociotechnical uncertainties, controversies, and public ambivalence about technology development. TA pioneers sought to broaden the spectrum of issues and actors in technological decision-making within a more general cultural move towards democratization, as various counter-movements (e.g. feminists, environmentalists, pacifist, antinuclear activists, patients' groups) in the United States and in Western Europe demanded that citizens have a say in all decisions that affect them personally (van Est and Brom 2012). It is thus against a background of political and cultural contesta-

\section{The 'meta-normativity' of TA is the embedded} normative ideal that a more pluralistic process will produce better outcomes and benefits for society.

In what follows, we further articulate this diagnosis by distinguishing two ways in which TA is normative. First, building on examples from TA and related literature, we discuss TA's 'meta-normativity', that is, its aim to improve the process of political decision making around science and technology. We do so by articulating and critically discussing how present-day TA programs and processes engage in an ideal of democratizing decision-making processes and outcomes. Next, we explore TA's 'in-normativity': TA activities are imbued with the values, norms and moralities of both participants and TA practitioners. In these activities, power relations among involved participants often come at the exclusion of discussions about what constitutes the good life. We draw lessons for TA practice that attend to the methodological, practical, and political implications for TA and the broader context in which TA plays out. In order to constructively address the criticism of the normative deficit, we provide three recommendations to render inherent normativities visible in TA processes, and thereby amenable to reconsideration and change.

\section{The normativity of technology assessment}

The first type of normative deficit is widely discussed in the TA literature and concerns the democratic and participatory values that orient TA expertise (Delvenne and Parotte 2019; van Est 2019). Whereas at its origin in the 1970s, the aim of TA was to reduce the costs of technologies' detrimental effects by anticipating potential impacts of technology and providing policymakers with neutral scientific advice, TA subsequently became a process of ongoing dialogue that supported actors' decision-making processes. For instance, TA programs in Denmark and the Netherlands included participants and their perspectives into the process of assessing technologies (Smits et al. 1995). tion and broad recognition of the inadequacy of traditional institutions to deal with the challenges posed by reflexive modernization (Hennen 1999; Delvenne et al. 2011) that TA developed as a criticism of 'modernist' governing generally, and of customary ways of managing technology in society specifically (Schot 2003). These two mutually reinforcing factors help explain the turn from technology government to technology governance, and from 'expertocratic' to interactive, participatory TA (Petermann 2000; Cruz-Castro and Sanz-Menendez 2005). By including different stakeholder groups in discussions, interactive, constructive and participatory TA approaches acknowledge the diverse and sometimes conflicting character of stakeholders' normative positions.

The imperatives for inclusive and participatory decision-making touch upon two interrelated normative rationales, one substantive and the other procedural-democratic. While the first presents interactive decision-making as a means of achieving qualitatively better science and technology outcomes and/ or policies, the second takes interaction and inclusion as ends in themselves (Fiorino 1990). Accordingly, the first imperative is distinctly outcome- and policy-oriented, whereas the second centres on enhancing democracy and citizen/stakeholder empowerment, typically through deliberative and participatory processes. These rationales interweave in TA practice, as they reach substantively better policy outcomes through interactive and inclusive democratic processes. Furthermore, TA initiatives aim at both substantive and democratic benefits, from democratizing technology to initiating social learning and opening up opportunities for conflict resolution, among many others (Abels 2007).

As Grunwald points out (2006), at the core of TA approaches is the need for robust results by ensuring independence (the results have to be elaborated during the process and unbiased by external interests), lack of prejudice (freedom from bias and a sufficiently broad research approach), and impartiality (no pref- 
erence given to certain value standpoints). However, any assessment requires some form of evaluation and is therefore normative by definition. TA's goal of improving society or democratising decision-making around emerging technologies still requires TA outcomes to take some normative position towards some decisions. TA exercises are therefore expected to bring to the fore a diverse and plural set of values without preferring one of them. However, this neutral stance is at odds with the goal of offering an evaluation of emerging technologies, which requires by definition to support some position and take a normative stance.

The 'meta-normativity' of TA is the embedded normative ideal that a more pluralistic process will produce better outcomes and benefits for society (Delvenne and Parotte 2019). Here, a gap emerges between the explicitly stated normative aims of TA of democratizing science and technology decision making processes and enabling better policy outcomes on the one hand, and the actual practice of TA on the other. In fact, by involving publics in policy making processes, selective choices in the design of activities and social control of participants are required. Unless the political and moral implications of these choices are made explicit and opened to debate, there is little to no opportunity to scrutinize how they influence the deliberative process.

\section{The normativity in technology assessment}

Intrinsic normativities in the TA processes and projects are also often overlooked. This happens in two ways: first, TA design is vulnerable to strategic game playing and power struggles when the divide between experts and lay people is reproduced. Second, the involvement of multiple stakeholders in an inclusive, cooperative manner does not guarantee that substantive issues involvement (Klüver et al. 2000; Klüver et al. 2016). Although most participatory activities aim at blurring boundaries between scientific facts and social values, they have tended in practice to reinforce these distinctions (Pellizzoni 2003). For instance, by reproducing a distinct separation between experts and lay people, these mechanisms reproduce a boundary within TA: whereas citizens are called upon to discuss scientific facts in virtue of their competences in ethics and values, they are not asked or invited to criticize the way scientific facts are constructed, selected and presented (Bruun Jensen 2005; Blok 2007).

When participatory exercises are implemented, the risk is to ignore the framing, selection and contestation of the expertise and neglecting the broader political and social contexts and the reproduction of traditional power-relations between experts and lay people. As noticed in some cases of constructive TA, issues such as start-up firms and regulation dominate the discussion in stakeholder workshops (Robinson 2010), whereas in exercises with lay people issues concerning desirability of science and technology and their implications for the 'good life' were tackled but rarely translated into action plans (Powell and Colin 2008). Hence, it does not suffice to engage a diverse set of stakeholders in discussions to guarantee democratic interaction, choices in process design will also have some consequences on what will be addressed as important. Some interests of uninvited lay citizens from 'the public' may often be unlikely to have a voice when only organized groups are engaged in technology assessment.

Moreover, by shifting the focus from impacts to the process of technological innovation, stakeholder focused TA exercises may exclude some lay questions on the good life from the debate. As Richard Sclove (2010), in a report evaluating the work of the US Office for TA, points out, some values are systematically neglected in transactions and negotiations among stakeholders with specific interests. Moral issues tend to be excluded from the discussion in expert-based assessment, when there is no consid-

\section{It should be priority for TA to engage in moral issues concerning the greater good in the debate or to discuss soft impacts (intrinsic normativites).}

about the desirability of a certain technology are taken up in the assessment. Let us look at each of these facets of 'in-normativity' a bit closer.

In addition to the expert guided activities that characterized the dawn of TA, many parliamentary TA offices in Europe built at least part of their activities on interactive and participative methodologies. Awareness initiatives, consensus conferences, scenario workshops, citizen hearings, or deliberative mappings, among other methods, were designed and implemented by TA institutes aiming at greater experts', stakeholders' or citizens' eration of the possible effect of technologies on social relations in daily life, and the question of how the technologically altered quality of community relations bears, in turn, on the basic ideals, structure and functioning of a democratic society.

This point is also made by Swierstra and Molder (2012), who show how some concerns about emerging technologies raised by citizens (e.g., the question of 'naturalness' in food industry) are discarded or minimized by technology developers. These concerns, typically non-quantifiable and ambiguous, are considered as less important, 'soft' impacts that do not merit atten- 
tion. If the goal of TA is to support decision-making guaranteeing democratic interactions, it should be priority for TA to engage in moral issues concerning the greater good in the debate or to discuss soft impacts.

Yet, the participatory process is not only concerned with the inclusion of different groups: it also requires a broadening of the substantive normative issues discussed. Although stakeholders and lay publics involved in TA activities are in a position to discuss the desirability of emerging science and technology, the normative dimension of such discussions is often neglected in favour of discussions concerning stakeholders' factual acceptance (Grunwald 1999, p. 175). In the majority of the cases, evaluative exercises on the normative acceptability of technologies are dismissed as pertaining to the subjective sphere, one that does not align well with TA's institutional commitment to provide neutral and objective knowledge. As it has been argued, this is a foundational myth (Torgersen 2019) that should urgently be reconsidered in the face of contemporary politics (Delvenne and Parotte 2019).

\section{Taking normativity to heart}

In this contribution, we distinguish between normativity of TA as the overarching moral goal of democratizing decision-making around science and technology ('meta-normativity') and normativity in TA as the values and moral standards intrinsic in TA ('in-normativity'). The so-called 'normative deficit' in TA, therefore, does not seem to imply that TA lacks a value dimension, as on the contrary such a dimension is visible both at the meta-level and at the level of practice. Instead, it can be understood as a lack of reflexivity within TA practices about their inherent normative inclinations and procedures. Our conceptualization allows us to discuss different types of criticism that emerge in the literature about TA's lack of acknowledgement for its normative dimensions. Not only the legitimacy of participa-
Amongst others, Grunwald (1999) and Brey (2012) have highlighted that TA activities should be integrated into an applied ethics perspective, which centres on normative aspects. There is also an acknowledgement that rather than adopting a unifying moral theory to evaluate emerging technologies, which is typical of traditional applied ethics approaches, TA initiatives should remain open to a normative pluralism: ethical technology assessment (Palm and Hansson 2006) and the ethical toolbox developed by the Ethical Bio-TA Tools project (Beekman et al. 2006) specifically address the challenge of broadening TA to include moral issues, an exploration of stakeholders' meanings and visions, the unpacking of their core values and an analysis of their moral arguments.

In order to escape the pitfalls of a normative deficit, TA practitioners would do well to:

1. make visible how actors involved in deliberation actually negotiate the terms of their engagement rather than assuming that deliberation improves the quality of decisions and enhances democracy per se;

2. open up discussion among all involved parties on the normativities of deliberative engagement, including the process norms that govern interaction (e. g. reciprocity) and the substantive biases inherent in discourses in and around TA;

3. acknowledge that TA mobilizes both a substantive and procedural normative ideal of good decision-making on science and technology and scrutinize these guiding normative principles.

These recommendations encourage a reflection on a range of normative questions that have methodological, practical, and political implications. TA institutions would do well to foster this capacity for reflection around procedural and substantive normativities instead of promoting an unrealistic idea of neutrality. If such aspects are not taken into account, TA appears to be at odds with its own aims and promises. From the viewpoint of sustain-

\section{TA institutions would do well to foster this capacity for reflection} around procedural and substantive normativities instead of promoting an unrealistic idea of neutrality.

tory exercises, its effectiveness for democratic purposes and the way consensus around one evaluation is reached require more investigation. TA exercises also tend to reproduce norm-laden distinctions in their set-up (fact/value or expert/lay person) and do not always engage in explicit explorations of participants' normative stances and moral visions. How can TA initiatives offer robust assessments of new technologies without addressing the very central question of the intrinsic normativity of such evaluations and discussing the moral assumptions that they entail? ing TA in contemporary knowledge-based economies, TA runs the risk of institutional irrelevance, as when parliamentary TA offices are downsized, or when TA's proximity to the establishment leads to accusations that TA hampers truly democratic policy-making (van Oudheusden et al 2015; Delvenne and Parotte 2019). What is needed then is the development of a capacity for critical self-reflection on the norms, assumptions, and aims that inform TA agendas, in ways that resonate with TA attempts at bringing reflexivity into science and technology governance. 
Even if issues about the good life and ethical perspectives are addressed and taken seriously in TA activities, it remains to be seen how they can be transformed into political action in ways that do justice to the vast plurality of views and concerns. Should policy makers make decisions based on a TA report that restricts itself to spelling out different positions? Alternatively, should TA also propose some positions as better for society from its own normative position? What priority, if any, should normative ethical arguments have over other types of assessment (e.g. economic impact assessment)?

Our article is meant as a contribution to addressing these kinds of questions, and to ongoing debates about the rightful place of science and technology in society, especially in the wake of EU-wide policy agendas. As van Lente and colleagues (2015) point out, these agendas explicitly bring ethics into science and technology-based innovation. We contend that if the collective pursuit of ethical innovation is to prove fruitful, societies should not only critically reflect on the ethics of science and technology, but also on the ethics, visions, and principles that guide, and potentially shape, processes aiming at governing innovation, such as TA.

\section{References}

Abels, Gabriele (2007): Citizen involvement in public policy-making. Does it improve democratic legitimacy and accountability? The case of pTA. In: Interdisciplinary Information Sciences 13 (1), pp. 103-116.

Beekman, Volkert et al. (2006): Ethical bio-technology assessment tools for agriculture and food production. Final Report Ethical Bio-TA Tools. Available online at https://estframe.net/ethical_bio_ta_tools_project/content_2/ text_2c81d261-b7a8-43e8-8f1e-d724b43e2ba3/1346076907647/et1_final_report_ binnenwerk_59p.pdf, last accessed on 18.02.2019.

Blok, Aders (2007): Experts on public trial. On democratizing expertise through a Danish consensus conference. In: Public Understanding of Science 16 (2), pp. 163-182.

Brey, Philip (2012): Anticipatory ethics for emerging technologies. In: NanoEthics 6, pp.1-13.

Bruun Jensen, Casper (2005): Citizen projects and consensus-building at the Danish Board of Technology. On experiments in democracy. In: Acta Sociologica 48 (3), pp. 221-235.

Cruz-Castro, Laura; Sanz-Menendez, Luis (2005): Politics and institutions. European parliamentary technology assessment. In: Technological Forecasting and Social Change 72 (4), pp. 429-448.

Decker, Michael; Ladikas, Miltos (eds.) (2004): Bridges between science, society and policy. Berlin: Springer.

Delvenne, Pierre; Parotte, Celine (2019): Breaking the myth of neutrality. Technology assessment has politics, technology assessment as politics. In: Technological Forecasting and Social Change 139, pp. 64-72.

Delvenne, Pierre; Fallon, Catherine; Brunet, Sebastien (2011): Parliamentary technology assessment institutions as indications of reflexive modernization. In: Technology in Society 33 (1-2), pp. 36-43.

Fiorino, Daniel (1990): Citizen participation and environmental risk. A survey of institutional mechanisms. In: Science, Technology, \& Human Values 15 (2), pp. 226-243.

Grunwald, Armin (1999): Technology assessment or ethics of technology? Reflec- tions on technology development between social sciences and philosophy. In: Ethical Perspectives 6 (2), pp 170-182.

Grunwald, Armin (2004): The normative basis of (health) technology assessment and the role of ethical expertise. In: Poiesis \& Praxis 2 (2-3), pp. 175-193.

Grunwald, Armin (2006): Scientific independence as a constitutive part of parliamentary technology assessment. In: Science and Public Policy 33 (2), pp. 103-113.

Hennen, Leonhard (1999): Participatory technology assessment. A response to technical modernity? In: Science and Public Policy 26 (5), pp.303-312.

Kiran, Asle; Oudshoorn, Nelly; Verbeek, Pieter-Paul (2015): Beyond checklists. Toward an ethical-constructive technology assessment. In: Journal of Responsible Innovation 2 (1), pp. 5-19.

Klüver, Lars et al. (2000): EUROpTA. European participatory technology assessment. Participatory methods in technology assessment and technology decision-making. Copenhagen: Danish Board of Technology. Available online at http://www.tekno.dk/pdf/projekter/europta_Report.pdf, last accessed on 18.02.2019.

Klüver, Lars; Nielsen, Rasmus; Jorgensen, Marie-Louise (eds.) (2016): Policyoriented technology assessment across Europe. Expanding capacities. London: Palgrave Macmillan.

Lucivero, Federica; Swierstra, Tsjalling; Boenink, Marianne (2011): Assessing expectations. Towards a toolbox for an ethics of emerging technologies. In: NanoEthics 5 (2), pp. 129-141.

Lucivero, Federica (2016): Ethical assessments of emerging technologies. Appraising the moral plausibility of technological visions. Cham: Springer.

Palm, Elin; Hansson, Sven Owen (2006): The case for ethical technology assessment (eTA). In: Technological Forecasting and Social Change 73 (5), pp. 543-558.

Petermann, Thomas (2000): Technology assessment units in the European parliamentary systems. In: Norman Vig and Herbert Paschen (eds.): Parliaments and technology. New York: State University Press, pp. 37-65.

Pellizzoni, Luigi (2003): Knowledge, uncertainty and the transformation of the public sphere. In: European Journal of Social Theory 52 (1), pp. 327-355.

Powell, Maria; Colin, Mathilde (2008): Meaningful citizen engagement in science and technology. What would it really take? In: Science Communication 30 (1), pp. 126-136.

Rip, Arie (2015): Technology assessment. In: International Encyclopedia of the Social \& Behavioral Sciences. Oxford: Elsevier, pp. 125-128.

Robinson, Douglas (2010): Constructive technology assessment of emerging nanotechnologies experiments in interactions. Enschede: University of Twente.

Schot, Johan; Rip, Arie (1997): The past and future of constructive technology assessment. In: Technological Forecasting and Social Change 54 (2-3), pp. 251-268.

Schot, Johan (2003): The contested rise of a modernist technology politics. In: Thomas Misa, Philip Brey and Andrew Feenberg (eds.): Modernity and technology. Cambridge: MIT Press, pp. 257-278.

Sclove, Richard (2010): Reinventing technology assessment. A 21 ${ }^{\text {st }}$ century model. Washington, DC: Woodrow Wilson International Center for Scholars. Available online at https://www.wilsoncenter.org/sites/default/ files/ReinventingTechnologyAssessment1.pdf, last accessed on 18. 02.2019.

Smits, Ruud; Leyten, Jos; Hertog, Pim (1995): Technology assessment and technology policy in Europe. New concepts, new goals, new infrastructures. In: Policy Sciences 28 (3), pp. 271-299. 
Swierstra, Tsjalling; Molder, Hedwig (2012): Risk and soft impacts. In: Sabine Roeser, Rafaela Hillerbrand, Per Sandin and Martin Peterson (eds.): Handbook of Risk Theory. Dordrecht: Springer, pp. 1049-1066.

Torgersen, Helge (2019): Three myths of neutrality in TA. How different forms of TA imply different understandings of neutrality. In: Technological Forecasting and Social Change 139, pp. 57-63.

van Eijndhoven, Josee (1997): Technology assessment. Product or process? In: Technological Forecasting and Social Change 54 (2-3), pp. 269-286. van Est, Rinie; Brom, Frans (2012): Technology assessment. Analytic and democratic practice. In: Ruth Chadwick (ed.): Encyclopedia of applied ethics. San Diego: Academic Press, pp.306-320.

van Est, Rinie (2019): Thinking parliamentary technology assessment politically. Exploring the link between democratic policy-making and parliamentary TA. In: Technological Forecasting and Social Change 139, pp. 48-56.

van Lente, Harro; Swiestra, Tsjalling; Joly, Pierre (2015): Mobilizing technology assessment for responsible innovation. Philosophies, ethics and stakeholders. $2^{\text {nd }}$ European Technology Assessment Conference. Berlin, Germany, 25.-27.02.2015

van Oudheusden, Michiel; Charlier, Nathan; Rosskamp, Benedikt; Delvenne, Pierre (2015): Broadening, deepening, and governing innovation. Flemish technology assessment in historical and socio-political perspective. In: Research Policy 44 (10), pp. 1877-1886.

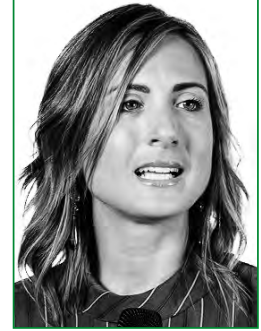

\section{DR. FEDERICA LUCIVERO}

is a Senior Researcher in Ethics and Data at the Ethox Centre, University of Oxford. Her expertise spans across ethics and social studies of science and technology, bioethics, governance of innovation, philosophy of science and technology. In 2016 she published a monograph with the title Ethical Assessments of Emerging Technologies (Springer).

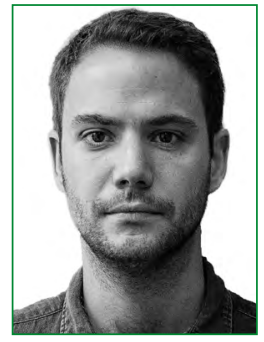

\section{DR.PIERRE DELVENNE}

is a Research Associate of the Fund for Scientific Research (FNRS), Lecturer at the University of Liège (Department of Political Science), and Co-Director of SPIRAL Research Centre. Pierre has published extensively in his areas of expertise: Technology Assessment, bioeconomy and, more broadly, science and technology in society.

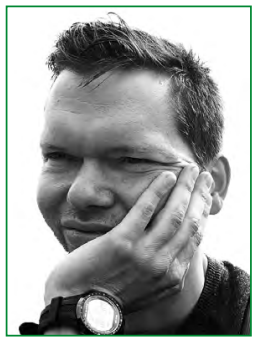

\section{DR. MICHIEL VAN OUDHEUSDEN}

researches the governance of new and emerging technologies and nuclear science and engineering. As an embedded sociologist at the Belgian Nuclear Research Center, he regularly reaches out to policymakers, scientists, civil society, and citizens with a view towards inciting responsible research and innovation in radiation protection.

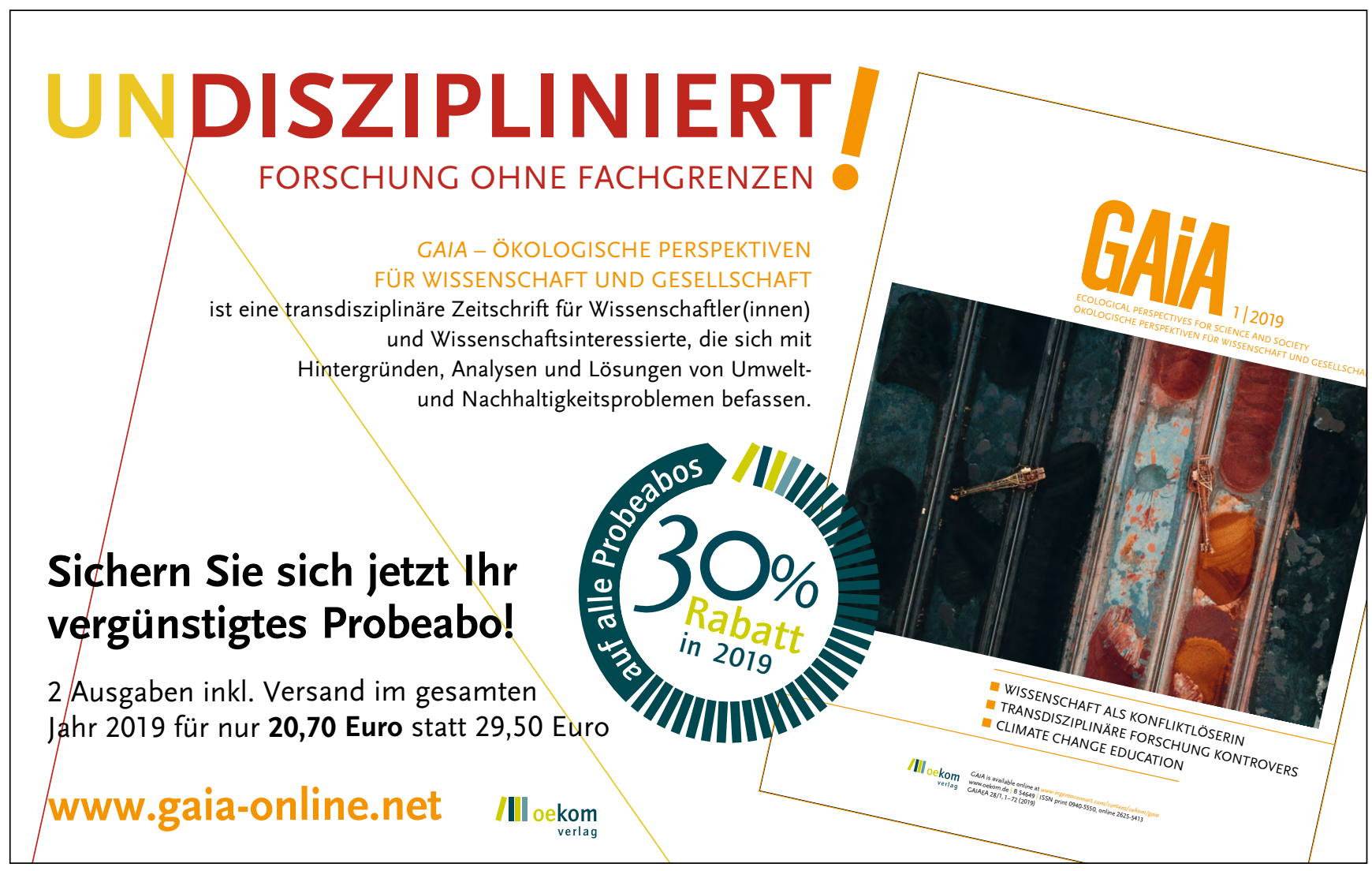




\title{
Max Weber revisited
}

\author{
Die „Wertbeziehung(en)“ der Technikfolgenabschätzung
}

Leonhard Hennen, Institut für Technikfolgenabschätzung und Systemanalyse (ITAS), Karlsruher Institut für Technologie (KIT),

Karlstr.11, 76133 Karlsruhe (leonhard.hennen@kit.edu)

In der aktuellen Debatte um die normativen Grundlagen der Technikfolgenabschätzung (TA) stehen Forderungen nach einer eindeutigen Positionierung der TA in technologiepolitischen Auseinandersetzungen neben Positionen, die an der Rolle der TA als neutraler Beobachter solcher Debatten festhalten wollen. Der Beitrag versucht, durch den Rekurs auf Max Webers kritische Stellungnahmen im ähnlich gelagerten Werturteilsstreit Anfang des 20. Jahrhunderts zur Klärung der Rolle von TA beizutragen. Es wird gezeigt, dass für Max Weber, anders als oft behauptet, Werturteilsfreiheit und engagierte Wissenschaft miteinander vereinbar waren. Für Max Weber war Wissenschaft ohne einen expliziten Bezug auf Werte nicht vorstellbar. Entsprechend kann (und sollte) TA sich ihrer Wertbeziehungen vergewissern, sie auch offensiv vertreten, ohne deshalb den Anspruch werturteilsfreier wissenschaftlicher Analyse aufzugeben.

\section{Max Weber revisited}

The value relation(s) of technology assessment

In the current debate on the normative foundations of technology assessment (TA), demands for TA to explicitly take a political stance in technology policy making coexist with positions holding on to TA's traditional role as a distanced observer of policy making. The present paper tries to clarify TA's role by revisiting Max Weber's critical comments in the so-called "Werturteilsstreit" (Value Judgment Dispute) at the beginning of the $20^{\text {th }}$ century. It is argued that, contrary to what is often stated, for Max Weber scientific analysis refraining from value judgments and engaged scientific intervention are consistent with each other. Scientific analysis, for Weber, is impossible to conceive of without explicit reference to societal values. TA accordingly can (and should) be clear about its own value relations (Wertbeziehungen), and hold on to them in political debate, without necessarily abandoning its ambition of proper and distanced scientific analysis.

Keywords: Werturteilsfreiheit, politics of TA, Max Weber

This is an article distributed under the terms of the Creative Commons Attribution License CCBY 4.0 (https://creativecommons.org/licenses/by/4.0/)

https://doi.org/10.14512/tatup.28.1.27
Die aktuelle Diskussion über die Frage, ob und inwieweit Technikfolgenabschätzung (TA) den Anspruch eines neutralen knowledge broker (Pielke 2007) in umstrittenen technologiepolitischen Fragen aufrechterhalten kann (oder jemals berechtigt war, einen solchen zu behaupten) und nicht vielmehr selbst normativ begründete Positionen beziehen sollte (bzw. implizit immer schon bezogen hat), ist angesichts der vielfältigen normativen Bezüge, in denen TA als hybride Praxis zwischen Wissenschaft und Politik steht, mehr als berechtigt. Feststellbar ist dabei eine unvermittelte Koexistenz von starken Plädoyers für offen normative technologiepolitische Stellungnahmen einerseits und einem (irgendwie gearteten) Festhalten an der Rolle des wissenschaftlich distanzierten Beobachters andererseits. ${ }^{1}$ In dieser Situation kann die Erinnerung an eine ähnlich gelagerte historische Diskussion hilfreich sein: den sogenannten „Werturteilsstreit“ Anfang des 20. Jahrhunderts. Bekanntlich war der Ausgangspunkt dieses Streites - durchaus ähnlich der aktuellen Diskussion in der TA-Community - die Frage nach der (Un-)Möglichkeit, konkrete werthaltige Handlungsempfehlungen an die Politik aus der wissenschaftlichen Analyse abzuleiten. Max Weber stellte sich in dieser Diskussion gegen die sogenannten Kathedersozialisten, nach deren Auffassung es Aufgabe der Wissenschaft (d.h. im vorliegenden Fall der Nationalökonomie) sei, in der um die Jahrhundertwende drängenden sozialen Frage nicht nur Stellungnahmen zur Sozialpolitik zu erarbeiten. Sie waren darüber hinaus der Ansicht, dass sich werthaltige, praktisch-politische Programme wissenschaftlich begründen ließen. Ihre Zielsetzung war es dabei, durch eine verbesserte Lage der Arbeiterklasse gerade dem Erstarken sozialistischer Kräfte in der Politik entgegenzuwirken. Die in diesem Kontext entstandenen Arbeiten und Stellungnahmen Max Webers haben für die wissenschaftstheoretische Grundlegung der Sozialwissenschaften eine wichtige Rolle gespielt. Sein auch in der TA diskutiertes Konzept der Werturteilsfreiheit (oft fälschlich verkürzt zu Wertfreiheit) der Wissenschaft steht hierfür. Max Weber hat aber daneben mit dem weniger rezipierten Begriff der Wertbeziehung als wesentlicher Voraussetzung (sozial-)wissenschaftlicher Praxis eine

1 Siehe dazu die Beiträge auf der 2. Europäischen TA-Konferenz in Cork im Mai 2017 (Hennen und Nierling 2018), der österreichischen TA18 im Juni 2018, und der letzten NTA-Konferenz in Karlsruhe im November 2018 sowie die Beiträge in diesem TATuP-Thema. 
durchaus komplexe Analyse der normativen Bedingungen von Wissenschaft vorgelegt. Ziel des vorliegenden Beitrages ist es, mittels der Lektüre ${ }^{2}$ dieser Analyse durch die TA-Brille die aktuelle Debatte nicht unbedingt durch neue Argumente anzureichern, aber die vorliegenden Argumente mittels einer Art Verfremdungs-Effekt in einem anderen, vielleicht aufschlussreichen Licht zu betrachten.

\section{Der praktische Wert „werturteilsfreier“ Wissenschaft}

Webers Grundposition ist bekanntlich gekennzeichnet durch eine strikte Trennung politischer (moralisch-praktischer) und wissenschaftlicher (analytischer) Tätigkeit, wie er sie etwa in seinem berühmten Aufsatz „Wissenschaft als Beruf“ (Weber 1919) begründet. Wissenschaft weist sich hier insofern als ,werturteilsfrei“ aus, als es keinen Weg gibt, aus dem „Sein“ bzw. aus der Analyse empirischer sozialer Verhältnisse, ein „Sollen“, etwa eben die Wünschbarkeit bestimmter sozialpolitischer Maßnahmen, zu begründen. Soweit, so bekannt, und es läge nun der Schluss nahe, der ja später auch oft gezogen worden ist, dass deshalb wissenschaftliche Politikberatung ihre Legitimität allein aus der Beschränkung auf die Rolle des neutralen, wertfreien knowledge broker gewinnen kann. Dass Webers Position, anders als oft behauptet, aber nicht (jedenfalls nicht umstandslos) als Referenz für Neutralität (in der TA) taugt, er die Sache mit den Werten jedenfalls etwas komplizierter sah, macht den Versuch eines Max Weber revisited für die aktuelle Debatte interessant. Die vor dem analytischen Zugriff auf die Wirklichkeit liegenden normativen Voraussetzungen wissenschaftlicher Arbeit nennt Weber ihre der (quasi technischen) Aufklärung über die zur Erreichung eines gegebenen „Zweckes“ (über dessen normative Begründung wissenschaftlich allerdings nichts auszusagen ist) geeigneten „Mittel“ und die dabei in Kauf zu nehmenden „Nebenfolgen“ (Weber 1988, S. 607). Das nennt Max Weber „Klarheit“ als den praktischen (politischen) Wert wissenschaftlicher Erkenntnis (ebd.) und dürfte in den Ohren des TA-Praktikers durchaus geläufig klingen. Der praktische Wert der Wissenschaft geht aber über das rein technische Zweck-Mittel-Verhältnis hinaus. Zwar kann wissenschaftlich nicht über die, die Praxis leitenden Werte (Zwecke) entschieden werden, aber die wissenschaftliche Wertediskussion kann dem Praktiker dabei helfen ,,sich selbst Rechenschaft zu geben über den letzten Sinn seines eigenen Tuns“ (ebd., 608). D. h. es kann Klarheit über die inneren Konsequenzen der Entscheidung zu einer bestimmten praktischen Stellungnahme geschaffen werden: Auf welchen Wertannahmen beruht sie (und welche schließt sie damit aus)? Was bedeutet es, sich praktisch durch diese anleiten zu lassen? Welche anderen Werte werden dadurch notwendig verletzt oder ignoriert und mit welchen Folgen? „Ihr dient, bildlich geredet, diesem Gott und kränkt jenen anderen, wenn ihr euch für diese Stellungnahme entschließt. Denn ihr kommt notwendig zu diesen und diesen letzten inneren, sinnhaften Konsequenzen, wenn ihr euch treu bleibt.“ (Weber 1988, S. 608) Dieser Beitrag der Wissenschaft zum praktischen Leben scheint Weber ,nicht so sehr wenig zu sein“(ebd.). Und das wäre auch in Bezug auf TA festzuhalten: Unter Enthaltsamkeit bzgl. eigener politischer Stellungnahmen den Protagonisten (technologie-)politischer Debatten zu Klarheit gegenüber ihrer eigenen Stellungnahme zu verhelfen, möglicherweise mit der Konsequenz diese zu relativieren, um auch den anderen Wertgesichtspunkten (Göttern) zu ihrem Recht zu verhelfen, scheint

\section{Im Sinne Webers ist Wissenschaft kein Selbstzweck, sondern legitimiert sich gesellschaftich durch ihren praktischen Wert.}

\begin{abstract}
„Wertbeziehung“. Es ist dieser Begriff mit dem Weber die nicht nur unvermeidliche, sondern im Hinblick auf die Gewährleistung praktischer Relevanz oder gar des Sinns wissenschaftlicher Tätigkeit notwendige normative Prägung von Wissenschaft anspricht - und zwar durchaus im Sinne engagierter Wissenschaft.

Zunächst einmal ist festzuhalten, dass im Sinne von Webers Ausführungen in „Wissenschaft als Beruf“ Wissenschaft natürlich kein Selbstzweck ist, sondern sich gesellschaftlich durch ihren praktischen Wert legitimiert (sozusagen ihr grundlegender Wertbezug), der darin besteht, dass sie einen Beitrag zur Lösung gesellschaftlicher Probleme leistet. Dieser wiederum besteht in
\end{abstract}

2 Bezug genommen wird auf drei zentrale Texte Webers: „Die ,Objektivität sozialwissenschaftlicher und sozialpolitischer Erkenntnis" (1904), „Der Sinn der ,Wertfreiheit' der soziologischen und ökonomischen Wissenschaften“ (1917) und "Wissenschaft als Beruf" (1919). nicht eben wenig zu sein, wenn auch die Aussichten, dass dies gelingt, je nach politischer Wetterlage, nicht immer gut sein mögen. Und dies impliziert - wie ich meine - jedenfalls mehr als distanziertes Knowledge-Brokering, sondern ist engagierte Gesellschaftsberatung im Sinne sich einmischender Aufklärung der Praxis. Max Weber hatte eine Begründung der praktischen Relevanz der Sozialwissenschaften (bzw. in seiner damaligen Diktion der Kulturwissenschaften) im Sinne. Aus heutiger TA-Sicht würde man ergänzen, dass zu solcher „Klarheit“ transdisziplinäre Forschung, d. h. das Zusammenwirken einer Vielzahl wissenschaftlicher Disziplinen im Dialog mit einem weiten Spektrum gesellschaftlicher Interessen und Erwartungen, notwendig ist. Ohne diesen Aufwand ist „Klarheit“ im Sinne der öffentlichen Selbstvergewisserung über die Konsequenzen der verschiedenen möglichen Stellungnahmen zu einem praktischen Problem, nicht zu erlangen. 


\section{Die wertbezogene Konstitution des Gegenstands wissenschaftlicher Analyse}

Werturteilsfreiheit von Wissenschaft impliziert, wie oben gezeigt, zunächst also durchaus (und nicht nur nebenbei, sondern als gesellschaftliche Aufgabe der Wissenschaft) die Möglichkeit einer wissenschaftlichen Diskussion der Beziehung von Mitteln und Zwecken sowie der, die letzteren begründenden Wertideen in praktisch-aufklärender Absicht. Wertfrei ist sie daher nicht. Sie kann es darüber hinaus aber auch in einem, ihre epistemologischen Voraussetzungen betreffenden Sinn nicht sein. Neben den „Regeln der Logik und Methodik“ zählt zu den Voraussetzungen wissenschaftlicher Arbeit, über die der Wissenschaftler sich Rechenschaft ablegen muss, ,[...] dass das, was bei der Wissenschaft herauskommt, wichtig im Sinne von, wissenswert" sei“ (Weber 1988, S. 599). Und hier, so Weber, ,[...] stecken nun offenbar alle unsere Probleme darin" (ebd.), weil diese Voraussetzung nicht wiederum wissenschaftlich beweisbar ist. „Keine Wissenschaft ist absolut voraussetzungslos, und keine kann für den, der diese Voraussetzungen ablehnt, ihren eigenen Wert begründen“" (ebd., S. 610). In Bezug auf TA wäre also zunächst festzuhalten, dass natürlich auch sie ihre eigenen Grundlagen oder ihre Mission nicht aus sich selbst begründen kann. Vielmehr wird hier eine vorwissenschaftliche (politische) Entscheidung getroffen, und zwar nicht nur dann, wenn man sich für eine dezidiert politisch agierende und Stellung beziehende TA entscheidet (Delvenne und Parotte 2019), sondern auch dann, wenn man sich selbst als neutralen Beobachter verstehen möchte. Die Entscheidung für Neutralität in praktisch-politischen Debatten wäre so gesehen - unabhängig von der Frage, ob Neutralität möglich ist - als eine Entscheidung über die (politische) Rolle oder das Selbstverständnis von TA zu begreifen, die aus praktisch politischen Überlegungen getroffen wird und etwa auch als „foundational myth“ der TA taktisch motiviert sein kann (Torgersen 2019).

Mit den vorwissenschaftlichen Voraussetzungen verbindet sich eine wertende Beziehung von Wissenschaft auf Realität, und diese bestimmt auch den Objektbezug jeder wissenschaftlichen Untersuchung. „Wertbeziehung“ im engeren Sinne impliziert ,[...] die philosophische Deutung desjenigen spezifisch wissenschaftlichen Interesses, welches die Auslese und Formung eines wissenschaftlichen Objektes beherrscht" (Weber 1988, S. 511). Es ist also eine außerwissenschaftliche Reflexion, die das Erkenntnisinteresse des Wissenschaftlers begründet, und diese betrifft nicht nur die „Auslese“ des Gegenstandes als des zu untersuchenden Problems, sondern auch dessen „Formung“, d. h. wie dieser Gegenstand grundsätzlich aufgefasst wird bzw. unter welchem Gesichtspunkt er untersucht wird. Weber spricht in dieser Hinsicht auch von der „Kulturbedeutung“ des Gegenstandes und der Untersuchung. Durch die Wertbeziehung wird die wissenschaftliche Untersuchung sozusagen in praktische Beziehung zur Kulturwirklichkeit gesetzt, die durch Werte konstituiert wird. Die Komplexität und Vielfalt der kulturellen Wirklichkeit macht eine vorwissenschaftlich wertgeleitete Auswahl der Fragestellung und der Perspektive nötig, weil schon eine einfache Beschreibung der Elemente der Wirklichkeit und erst recht die Aufdeckung von ursächlichen Zusammenhängen ohne eine solche Entscheidung unmöglich ist. Es kommt darauf an, die Wirklichkeit unter einem Aspekt zu erfassen, der „kulturbedeutend" ist, also möglichst etwas Wesentliches oder Typisches der soziohistorischen Realität erfasst (ebd., S. 180, 182). Auch dieser Gedanke lässt sich aus dem Kontext wissenschaftstheoretischer Begründung der „Kulturwissenschaften“ in die Welt der TA übertragen: Problemorientierte Forschung gewinnt die Aspekte, unter denen Wirklichkeit thematisch wird, aus den Problemen, die die gesellschaftliche Diskussion und die Politik bestimmen.

\section{In Bezug auf TA ist festzuhalten, dass sie ihre eigenen Grund- lagen oder ihre Mission nicht aus sich selbst begründen kann.}

Webers Formulierungen legen nahe, dass es darauf ankommt, diejenige Problemperspektive einzunehmen, die sozusagen gesamtgesellschaftlich relevant ist, d. h. den Kern gesellschaftlicher Problemwahrnehmung trifft. Dabei würde sich natürlich unmittelbar die Frage stellen, wie dies zu bestimmen wäre. Klar ist zunächst, dass eine solche Bestimmung selbst wieder dem kulturellen Wandel unterliegt. Mit dem kulturellen Wandel ändern sich auch die Forschungsgegenstände, weil die Gesellschaft sich sozusagen selbst unter anderen Problemgesichtspunkten thematisiert: ,[I]rgendwann wechselt die Farbe: die Bedeutung der unreflektiert (Hervorhebung des Autors) verwerteten Gesichtspunkte wird unsicher, der Weg verliert sich in der Dämmerung“ (ebd., S. 214). Damit wechselt nun auch die Wissenschaft ihren „Begriffsapparat“ und sie ,zieht jenen Gestirnen nach, welche allein ihrer Arbeit Sinn und Richtung zu weisen vermögen“ (ebd.). Wissenschaft unterliegt also selbst dem soziokulturellen Wandel, den sie untersuchen will, und ist geprägt (mehr noch: muss sich, um sinnvoll zu sein, prägen lassen) von Wertideen, die im Idealfall aus den wesentlichen, drängenden Fragen der jeweiligen Gegenwart gespeist sind. Damit ist eine normative Imprägnierung gerade einer Forschung in politikberatender Absicht immer schon durch den Zeitgeist gegeben, wie sich etwa an den für TA zentralen Konzepten wie Risiko oder Nachhaltigkeit festmachen ließe (Grunwald 2018). Eine solche Imprägnierung scheint wohl in der Tat aus Webers Sicht nicht nur unvermeidbar, sondern auch wünschbar. Dies sollte aber sozusagen nicht auf Kosten der Schärfe des kritischen Blickes geschehen. Wertbezug heißt im Sinne Webers nicht Übernahme eines vermeintlichen gesellschaftlichen Konsenses darüber, was das drängende Problem der Zeit oder im Interesse des Gemein- 
wohls sei oder - wie etwa bei den von Weber kritisierten Kathedersozialisten - die Orientierung am ,Daseinsinteresse des Staates" als letztem Wert wissenschaftlicher Erkenntnis (Weber 1988, S. 539). Im Gegenteil, man dürfe sich nicht „,bei irgendeiner [...] durch Konvention geschaffenen Selbstverständlichkeit gewisser noch so weit verbreiteter praktischer Stellungnahmen wissenschaftlich beruhigen“ (ebd., S. 502). Für Weber ist es „die spezifische Funktion der Wissenschaft", dass sie sich kritisch zur Wirklichkeit verhält, ,indem ihr das konventionell Selbstverständliche zum Problem wird“" (ebd.).

Das heißt, auch Technikfolgenforschung entscheidet über die sie leitenden Wertgesichtspunkte nicht unabhängig von technologiepolitischen Debatten und den hier herrschenden Positionen, sie muss diese im Gegenteil in Rechnung stellen. Aber sie muss dann die sie leitenden Wertideen selbst setzen und vertreten. Damit ist sowohl die Bemühung um eine Forschungsperspektive, die von einem breitest möglichen politischen Konsens gedeckt ist (wie z. B. in der politikberatenden Praxis des Büros für Technikfolgen-Abschätzung beim Deutschen Bundestag (TAB) durch die Rolle der parlamentarischen Berichterstatter intendiert), wie auch die Wahl einer spezifischen Auftraggeberoder Stakeholder-Perspektive, schließlich aber auch die Begründung einer eigenen kritischen Forschungsperspektive legitimiert, solange diese Wahl als vorwissenschaftliche transparent bleibt und die Untersuchung selbst gemäß den Standards werturteilsfreier Wissenschaft durchgeführt wird.

\section{Wissenschaft und politisches Engagement}

Ein in der aktuellen TA-Debatte wichtiges Argument gegen das Postulat der wie auch immer verstandenen politischen Neutralität der TA bzw. besser der Distanziertheit gegenüber der politischen Kontroverse ist es, dass Wertfreiheit der praktischen wissenschaftlichen Arbeit nicht möglich sei, schon weil jeder TA-Praktizierende ja mit einer gewissen nicht einfach ausschaltbaren persönlichen Einstellung zur vorliegenden Fragestellung an die Arbeit herangehe (siehe hierzu z. B. das von Bauer und Kastenhofer 2019 herausgearbeitete Repertoire von „Rollen“ in der TA-Praxis). Interessanterweise zeigt sich, dass auch Weber als Verfechter der Werturteilsfreiheit nicht nur nicht blauäugig gegenüber solchen Beobachtungen war, sondern ein praktisches Verhältnis oder Wollen in der Sache geradezu als Impetus der wissenschaftlichen Arbeit ansah. Anlässlich der Übernahme der Redaktion der Zeitschrift Archiv für Sozialwissenschaften und Sozialpolitik betont Weber, dass aufgrund des notwendigen Bezugs der Sozialwissenschaften auf praktische Fragen, schon „die bloße Anerkennung eines wissenschaftlichen Problems in Personalunion steht mit einem bestimmt gerichteten Wollen lebendiger Menschen." (Weber 1988, S. 158) Ein solches Wollen, eine bestimmte „Wertidee“ (ebd., S. 159), welche die Problemwahrnehmung und auch die Wahrnehmung der Dringlichkeit ihrer Lösungen leitet, hält er für unerlässlich, wenn es um eine kritische Auseinandersetzung mit Fragen praktischer Politik geht. Die Kritik praktischer Politik, worin er - hier nun sozusagen die Grenzen der reinen Forschung, um die es ihm in seinen methodologischen Arbeiten geht, überschreitend - durchaus die Aufgabe der Zeitschrift sah, geht immer von einem die eigenen Ideale leitenden „Wertaxiom“ aus und wendet sich gegen andere (ebd., S. 156 f.).

In diesem Zusammenhang beschreibt Weber den kathedersozialistischen Geist der Gruppe von Wissenschaftlern um das Archiv als legitimen praktischen Antrieb und auch Grund der anhaltenden Bedeutung der Zeitschrift. Dieses gemeinsame Ethos bestand im Interesse an der Hebung des Lebensstandards der Arbeiter auf der Grundlage kapitalistischer Wirtschaftsform. Aus dieser Perspektive wurde die Politik kritisch kommentiert und wurden praktisch-politische Vorschläge erarbeitet. ${ }^{3}$ Es kommt aber bei der wissenschaftlich unterfütterten politischen Kritik darauf an, ,in jedem Augenblick den Lesern und sich selbst scharf zum Bewusstsein zu bringen, welches die Maßstäbe sind, an denen die Wirklichkeit gemessen und aus denen das Werturteil abgeleitet wird“" (ebd., S. 157). Eine wissenschaftlich fundierte, praktische Kritik von Politik ist ohne einen eigenen außerwissenschaftlichen Standpunkt nicht möglich. Weber geht an dieser Stelle ganz offensichtlich über die Aufgabe der reinen Wertediskussion (s. o.) hinaus, die sich ja noch distanziert zu unterschiedlich begründeten Wertgesichtspunkten hält, und vertritt als Aufgabe einer wissenschaftlichen Zeitschrift für politische Fragen ein durchaus selbst wertgeleitetes Eingreifen in politische Debatten. Man könnte demnach vielleicht von zwei unterschiedlichen Modi ,politikberatender“ Wissenschaft sprechen, einem distanziert aufklärenden und einem engagiert eingreifenden. Es kommt bei letzterem aber darauf an, dass der eigene (praktisch-politisch, ethisch, weltanschaulich begründete) Wertgesichtspunkt klar erkennbar bleibt.

In Webers Konzept der Wertbeziehung hat ein über das reine Forschungsinteresse hinausgehender Wertbezug also durchaus einen Platz. Dieser kommt dann zum Tragen, wenn sich Wissenschaft (wie im vorliegenden Falle einer Zeitschrift für Sozialpolitik und nicht allein für Sozialwissenschaft) praktisch-politisch äußert. Die Autoren des Archivs für Sozialpolitik und Sozialwissenschaft teilen das Interesse an sozialpolitischen Problemen (die Lage der Arbeiterklasse) und prägen durch die „Wahlverwandtschaft ähnlicher Ideale“ der Zeitschrift einen bestimmten „Charakter“ in der Behandlung politischer Fragen auf (ebd., S. 158 f.). Einen solchen „Charakter“ sieht Weber offensichtlich als legitime Motivation politisch engagierter Wissenschaft an, unterscheidet diesen aber scharf von einer „Tendenz“, die sozusagen der Befassung mit solchen Problemen von vornherein eine politische Färbung aufprägt und etwa die Zeitschrift auf ein politisches Lager festlegen würde.

3 Weber stellt sich also nicht eigentlich gegen die sogenannten Kathedersozialisten, sondern sieht hier einen besonderen Wertbezug realisiert. Er stellt sich gegen die Verwechslung eines „wertvollen“ Bezugs auf die Realität als Forschungsgegenstand und die unzulässige stillschweigende Unterstellung, dass sich diese Werte aus der wissenschaftlichen Analyse begründen ließen. 
Es liegt auf der Hand, analog für die TA-Community Elemente eines solchen „Charakters“ zu konstatieren: Ein gewisses kritisches Verhältnis zur Frage der zivilisatorischen Bedeutung wissenschaftlich-technischer Innovation gehört sicherlich ebenso zum (legitimen) Selbstverständnis der Zunft wie etwa die Präferenz für inklusorische/partizipative Verfahren der Problemidentifikation und -bearbeitung. Der TA(-Community) werden Wissenschaft und Technologie immer unter bestimmten Wertgesichtspunkten zum Problem: Diese können solche sein, die durch einen weitgehenden gesellschaftlichen Konsens über die Kulturbedeutung einer Frage, wie etwa der des Klimawandels, getragen sind; aber auch solche, die dezidiert als gegen den Mainstream gewandte Fragen etwa nach ökologischer Nachhaltigkeit oder sozialer Gerechtigkeit gewählt sind. Auch folgt TA in der Bearbeitung solcher Probleme bestimmten, selbst nicht wissenschaftlich begründbaren (und etwa populistischen Wertideen diametral entgegenstehenden) Idealen, nämlich jenen wissenschaftlich-rationaler Analyse und demokratischer Deliberation. Die politische Aufgabe und Rolle von TA (zentraler Aspekt der „Politics of TA“, s. Hennen und Nierling 2019) ist es durchaus, diese Ideale zu vertreten und in der wissenschaftlich-beratenden Arbeit durchzusetzen. Dies impliziert aber keine apriorische Stellung zu praktisch-politischen Lösungsvorschlägen und in jedem Fall muss dort, wo die Entscheidung für eine Wertidee die Untersuchung motiviert, etwa dann, wenn ein bestimmtes Konzept von Nachhaltigkeit als normative Grundentscheidung der Neutralität darin liefern auch für die Haltung des ,providing something to everybody" Anschauungsmaterial, so etwa im Falle des frühen US-Amerikanischen Office of Technology Assessment (OTA) (Torgersen 2019, S. 59).

\section{TA als „Kulturwissenschaft"?}

Zum Schluss soll eine Frage nicht vermieden werden, mit der die Übung einer Fruchtbarmachung der ca. 100 Jahre alten wissenschaftstheoretischen Überlegungen Webers für die TA steht und fällt - und die hier nicht ausreichend thematisiert werden kann: Natürlich ist TA nicht mit Kulturwissenschaften im Sinne Webers gleichzusetzen. Es geht hier nicht um geistes- und sozialwissenschaftliche Forschung, sondern um inter- oder transdisziplinäre Forschung, orientiert an gesellschaftlich definierten Problemlagen. Dennoch kann die kulturwissenschaftliche Perspektive Webers - wie hoffentlich klargeworden ist - für unsere Praxis erhellend sein. Für Weber ist alle kulturwissenschaftliche Forschung problemorientierte Forschung, indem sie nur insofern Bedeutung gewinnt, als sie Kulturprobleme zum Gegenstand ihrer Analyse wählt, sich also bei der Auswahl der Fragestellung und des Gegenstandes davon leiten lässt, was kulturell bedeutsam ist. Hierin ist natürlich immer eine Wertung enthalten: eine Orientierung an Kulturwerten. Festgehalten werden kann jedenfalls, dass sich problemorientierter Forschung vom

\section{Eine wissenschaftlich fundierte, praktische Kritik}

\section{von Politik ist ohne einen eigenen außerwissenschaftlichen Standpunkt nicht möglich.}

die Analyse leitet, die zugrundeliegende Wertidee immer klar herausgearbeitet sein. Und was die scheinbar beste Lösung für sagen wir - eine nachhaltige Energiewirtschaft im Einzelnen ist, muss in jedem Fall unter Berücksichtigung verschiedener Werte (Wertediskussion, s. o.) Gegenstand der TA-Untersuchung sein und nicht schon als Tendenz vorgegeben.

Ebenso fatal wie eine wissenschaftliche Verschleierung der eigenen wertgebunden Position wäre es nach Weber aber ,wie es nur allzu oft geschieht, durch unpräzises Ineinanderschieben von Werten verschiedenster Art sich um die Konflikte zwischen den Idealen herumzutäuschen und ,jedem etwas bieten ' zu wollen.“ (Weber 1988, S. 157) Die Handlungsmaxime ,jedem etwas bieten zu wollen“, in welchem Sinne Neutralität als Kennzeichen politikberatender TA ja oft vertreten oder kritisiert wird, wäre damit sozusagen als die schlechte Variante von Distanziertheit zu verstehen, eine Form von Beobachterposition, die gerade nicht aufklärt, sondern die Komplexität und Konflikthaftigkeit der für ein vorliegendes Problem relevanten Wertgesichtspunkte verschleiert. Die Geschichte der TA und die Rolle des Konzepts
Typus TA, ebenso wie den Kulturwissenschaften, die Aufgabe stellt, die Wirklichkeit unter den Problemgesichtspunkten zu erfassen, die von kultureller Bedeutung sind, also unsere gegenwärtige Problemwahrnehmung prägen oder - und hier käme der Pluralismus von Werten zum Tragen - nach verschiedenen konkurrierenden Auffassungen prägen sollten. TA ist insofern Kulturwissenschaft im Sinne Webers, als uns Technik ja nicht in erster Linie unter dem technischen Aspekt ihres Funktionierens problematisch wird (das ist Sache des Ingenieurs), sondern hinsichtlich ihrer Kulturbedeutung, die im weiten Sinne verstanden in der gesellschaftlichen Auseinandersetzung über Fragen der Umweltauswirkungen (Umwelt als Kulturgut) ebenso zur Debatte steht wie in der Frage der potenziellen Veränderung sozialer Interaktionsformen (etwa durch Social Media).

\section{Literatur \\ Bauer, Anja; Kastenhofer, Karen (2019): Policy advice in technology assessment. Shifting roles, principles and boundaries. In: Technological Forecasting and Social Change 139, S. 32-41.}


Delvenne, Pierre; Parotte, Celine (2019): Breaking the myth of neutrality. Technology assessment has politics, technology assessment as politics. In: Technological Forecasting and Social Change 139, S. 64-72.

Grunwald, Armin (2018): Versteckte Normativitäten in der Technikfolgenabschätzung? Vortrag bei der Konferenz TA18 „Technikfolgenabschätzung und Normativität. An welchen Werten orientiert sich TA?", Wien, 11. Juni 2018. Hennen, Leonhard; Nierling, Linda (2019): The politics of TA. Introduction to the special issue of technological forecasting and social change. In: Technological Forecasting and Social Change 139, S. 17-22.

Pielke Jr., Roger (2007): The honest broker. Making sense of science in policy and politics. Cambridge: Cambridge University Press.

Torgersen, Helge (2019): Three myths of neutrality in TA. How different forms of TA imply different understandings of neutrality, In: Technological Forecasting and Social Change 139, S. 57-63.

Weber, Max (1904): Die „Objektivität“ sozialwissenschaftlicher und sozialpolitischer Erkenntnis. In: Ders. (1988): Gesammelte Aufsätze zur Wissenschaftslehre. Tübingen: J. C. B. Mohr, S. 146-214.

Weber, Max (1917): Der Sinn der „Wertfreiheit“ der soziologischen und ökonomischen Wissenschaften. In: Ders. (1988): Gesammelte Aufsätze zur Wissenschaftslehre. Tübingen: J. C. B. Mohr, S. 489-540.

Weber, Max (1919): Wissenschaft als Beruf. In: Ders. (1988): Gesammelte Aufsätze zur Wissenschaftslehre. Tübingen: J. C. B. Mohr. S. 582-613.

Weber, Max (1988): Gesammelte Aufsätze zur Wissenschaftslehre. Tübingen: J.C.B. Mohr.

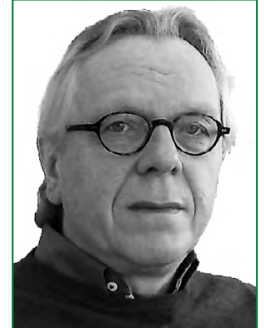

\section{DR. LEONHARD HENNEN}

arbeitet als Senior Scientist am ITAS und ist als Soziologe in zahlreichen internationalen Projekten zu Konzepten und Methoden der TA involviert. Seit 2005 ist er Koordinator der European Technology Assessment Group (TA Studien im Auftrag des Europäischen Parlamentes), von 1991 bis 2005 war er Projektmanager im Büro für TechnikfolgenAbschätzung beim Deutschen Bundestag.

\section{Zukünftige TATuP-Themen auf einen Blick ...}

Erscheinungstermine, Inhalte, Thema-Herausgeberinnen und -Herausgeber sowie die Veröffentlichungstermine der Call for Abstracts in kommenden TATuP-Ausgaben:

\section{TATuP 2019, Heft 2 (Juli)}

Thema: Digitalisierung und Entwicklung im Globalen Süden. Fortschritt durch Technologie?

Thema-Herausgeberinnen: Jessica Heesen, Laura Schelenz, Kerstin Schopp und Maria Pawelec (alle IZEW, Universität Tübingen)

Call for Abstracts: geschlossen

\section{TATuP 2019, Heft 3 (Dezember)}

Thema: Energiezukünfte: wissen, beraten, gestalten

Thema-Herausgeberin und -Herausgeber: Lisa Nabitz, Witold Roger Poganietz und Dirk Scheer (alle ITAS, KIT)

Call for Abstracts: geschlossen

\section{TATuP 2020, Heft 1 (April)}

Thema: Cybersicherheit

Thema-Herausgeber: Karsten Weber (OTH Regensburg),

Markus Christen (Universität Zürich) und Dominik

Herrmann (Universität Bamberg)

Call for Abstracts: ca. Mitte Mai 2019

\section{TATuP 2020, Heft 2 (Juli)}

Thema: Integrated Infrastructures

Thema-Herausgeber: Christian Büscher (ITAS, KIT), Bert Droste-Franke (EA European Academy) und Michael Ornetzeder (ITA, Wien)

Call for Abstracts: ca. Mitte September 2019

\section{TATuP 2020, Heft 3 (Dezember)}

Thema: Demokratie und Technikfolgenabschätzung

Thema-Herausgeber: Armin Grunwald (ITAS, KIT) und Thomas Saretzki (Leuphana Universität Lüneburg)

Call for Abstracts: ca. Februar 2020

\section{TATuP 2021, Heft 1 (April)}

Thema: Urbane Zukünfte/Smart Cities

Thema-Herausgeberin und -Herausgeber: Cordula Kropp (Universität Stuttgart) und Ulrich Ufer (ITAS, KIT)

Call for Abstracts: ca. Mai 2020 


\title{
"Wes Brot ich ess, des Lied ich sing"?
}

\author{
Technikfolgenabschätzung und ihre Auftraggeber
}

\begin{abstract}
Karen Kastenhofer, Institut für Technikfolgen-Abschätzung, Österreichische Akademie der Wissenschaften, Apostelgasse 23, 1030 Wien (kkast@oeaw.ac.at), (1) orcid.org/0000-0001-5843-6489

Leo Capari, Institut für Technikfolgen-Abschätzung, Österreichische Akademie der Wissenschaften (leo.capari@oeaw.ac.at), (1) orcid.org/0000-0002-7867-4975

Daniela Fuchs, Institut für Technikfolgen-Abschätzung, Österreichische Akademie der Wissenschaften (daniela.fuchs@oeaw.ac.at), (10 orcid.org/0000-0002-2202-1027

Walter Peissl, Institut für Technikfolgen-Abschätzung, Österreichische Akademie der Wissenschaften (wpeissl@oeaw.ac.at), (1) orcid.org/0000-0002-9993-0835
\end{abstract}

Weimer und Vining (1999) unterscheiden drei Rollen, die Wissenschafterlnnen in Politikberatung einnehmen können: den objective technician, den issue advocate und den client's advocate. Dieser Beitrag widmet sich jener Rolle, die in der gegenwärtigen Diskussion kaum reflektiert wird, aber dennoch für die Normativität von Technikfolgenabschätzung (TA) relevant ist: dem client's advocate. Basierend auf Daten aus einer empirischen internen Erhebung von Praxen, Konstellationen und Paradigmen der Politikberatung am österreichischen Institut für Technikfolgen-Abschätzung (ITA), stellen wir (1) das in den Projekten des Instituts realisierte Portfolio an Geldgebern bzw. Auftraggebern dar, setzen es (2) in Bezug zu den in den Projekten des ITA angesprochenen Issues und zu Ergebnissen aus vier projektspezifischen Fallstudien und formulieren (3) offene Fragen an die TA-Praxis und TA-Community.

\section{"Whose bread I eat, his song I sing"?}

Technology assessment and its clients

Weimer and Vining (1999) discern three roles for scientific policy advisers: the objective technician, the issue advocate, and the client's advocate. This contribution focuses on the latter - a role that is rarely reflected upon in current discussions about technology assessment (TA) practice. Based on empirical data on the practices, constellations, and paradigms prevalent in policy advice activities at the Austrian Institute of Technology Assessment (ITA), we (1) present the portfolio and characteristics of the institute's clients, (2) relate these to the issues addressed in the institute's projects and to four project-specific case studies, and (3) present open questions to the practice and community of TA pertaining to its relation to its clients.

Keywords: technology assessment, policy advice, client's advocacy

This is an article distributed under the terms of the Creative Commons Attribution License CCBY 4.0 (https://creativecommons.org/licenses/by/4.0/)

https://doi.org/10.14512/tatup.28.1.33

Submitted: 05.11.2018. Peer reviewed. Accepted: 07.02.2019

\section{Einführung}

Wissenschaftliche Politikberatung bedient die Schnittstelle von Wissenschafts- und Politiksystem, wie sie sich in modernen Gesellschaften ausgeprägt hat und institutionell wie diskursiv kontinuierlich stabilisiert wird. Sie ist somit unvermeidlich in der Situation, zwei gesellschaftliche Systeme miteinander zu verknüpfen und zugleich an deren fortwährender Differenzierung mitzuwirken. Wie diese Aufgabenstellung und die ihr immanente Paradoxie im Detail verstanden und prozessiert werden, hängt dabei von systemischen wie individuellen Faktoren ab: Wie sieht die institutionelle Landschaft in diesem Kontext aus? Welche bindenden Verfahren, welche politischen Traditionen gibt es? Wie positioniert sich eine Beratungsinstitution in dieser institutionellen Landschaft? Welche allgemeinen Prioritäten setzt sie und welche Paradigmen vertritt sie?

Während erstere Fragen jeweils in Bezug auf ein konkretes politisches System zu beantworten sind, können die letzteren Fragen vergleichend analysiert und diskutiert werden. Prominente Systematiken hierzu bieten Habermas (1963) in Hinblick auf unterschiedliche Modelle der Verschränkung von Wissenschaft und Politik (dezisionistisch, technokratisch und pragmatisch), Weimer und Vining (1999) in Hinblick auf unterschiedliche Werthaltungen und Priorisierungen von BeraterInnen (analytische Integrität, Verantwortung gegenüber dem Auftraggeber, Beitrag zu einer besseren Welt gemäß eigenen Überzeugungen) und Pielke (2007) in Hinblick auf unterschiedliche Konzeptionen von demokratischer Aushandlung einerseits (Interessensgruppenpluralismus versus Elitenkonflikt) und gesellschaftlicher Einbettung von Wissenschaft andererseits (lineares Modell versus Stakeholder-Modell). Am bekanntesten sind die hieraus resultierenden vier Typen pure scientist, science arbiter, issue advocate und honest broker (ebd.); für eine Auflistung alternativer Typologien, siehe Bauer und Kastenhofer (2019). Unterschiedliche Institutionalisierungsformen von Technikfolgenabschätzung (TA) finden sich in der Unterscheidung von TA-Ein- 
richtungen, die direkt an Parlamente angebunden sind, und TA-Instituten, die sich im akademischen Kontext (an Akademien oder Universitäten) institutionalisiert haben. Eine Typisierung nach primären Interaktionspartnern - Parlament, Regierung, Wissenschaft und Technik, Gesellschaft - findet sich in van Est et al. (2016).

Art und Bedeutung der Beziehung zwischen politikberatender Institution und Auftraggeber nehmen dabei allein Weimer und Vining (1999) in den Blick. Sie unterscheiden zwischen der Rolle eines objective technician, eines issue avocate und eines client's avocate und werfen damit die Frage auf, wie mit Interessen des Auftraggebers in wissenschaftlicher Politikberatung im Abgleich mit Normen der Objektivität und der eigenen Mission umzugehen ist. Dies ist einerseits selbst eine wertebasierte Entscheidung; andererseits schlägt sich eine Entscheidung zugunsten einer client's advocacy normativ nieder, indem sie Interessen und Werthaltungen des Auftraggebers in die Beratungspraxis einspeist.

In diesem Sinne lassen sich drei Fragen an die aus dem Projekt Pol[ITA] resultierenden Forschungsdaten stellen, welche Aufschluss über die bisherigen Forschungsprojekte des Institut für Technikfolgenabschätzung in Wien (ITA) geben: (1) Wer sind die Auftraggeber des ITA, welche Interessen und Werthaltungen repräsentieren sie und welche Interessen fließen daher potenziell in die Beratungspraxis ein? (2) Lassen sich Spuren einer client's advocacy in den Beratungsprojekten wiederfinden und (3) was folgt daraus für eine good practice in der TA.

\footnotetext{
Das Projekt „Pol[ITA] - Politikberatung am ITA“ wurde von Juni 2016 bis Juni 2018 am Institut für Technikfolgen-Abschätzung in Wien (ITA) von Karen Kastenhofer, Anja Bauer, Leo Capari, Daniela Fuchs, André Gazsó, Walter Peissl und Tanja Sinozic durchgeführt (Kastenhofer et al. 2018). Für die hier gedruckte Veröffentlichung wurden insbesondere eine in Pol[ITA] erstellte Datenbank aller am ITA durchgeführten Projekte (inklusive Auftraggeber, Projektart, bearbeitete Technologiefelder und Themen) sowie vier Fallstudien zu verstetigten Projektschienen des ITA (basierend auf Interviews mit involvierten TA-PraktikerInnen, Auftraggebern und Kooperationspartnern) herangezogen.
}

\section{Die Auftraggeber des ITA}

Ist eine TA-Einrichtung nicht direkt an ein Parlament angebunden, sondern wie das ITA an einer akademischen Einrichtung institutionalisiert (Nentwich und Fuchs 2018), findet sich typi-

\section{Beauftragungsart}

Antragsforschung

15

(8\%)

Auftragsforschung

90

$(46 \%)$

30
$(16 \%)$

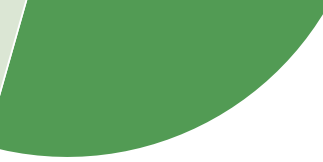


ein Viertel ordnet sich Eigenfinanzierung oder thematisch offener Fremdfinanzierung zu (letzteres insbesondere im Rahmen akademischer Qualifikationsarbeiten), so dass hier tatsächlich nur von einem Geldgeber, nicht aber von einem Auftraggeber im engeren Sinn gesprochen werden kann.

Wiederkehrende Geldgeber mit Auftraggeber-Status im engsten Sinn (Auftragsforschung) sind österreichische Ministerien, das Europäische Parlament und die österreichische Arbeiterkammer. Häufigste Geldgeber für Programmforschungsprojekte sind das Directorate-General for Research and Innovation der EU-Kommission über die großen Forschungsförderungsrahmenprogramme sowie die österreichische Forschungsförderungsgesellschaft (FFG). Häufigster Geldgeber für Antragsforschung ist der österreichische Wissenschaftsfonds (FWF). Private Auftraggeber schließt das ITA qua interner Kriterien aus. Der nach Förderhöhe weitaus relevanteste Geldgeber für Drittmittelprojekte sind österreichische Ministerien (knapp die Hälfte aller Fördermittel entstammen österreichischen Ministerien), gefolgt von der Europäischen Kommission (knapp ein Drittel). Weitere quantitativ wichtige Geldquellen stellen FWF und FFG dar.

Die Relevanz von Auftraggebern bemisst sich allerdings nicht ausschließlich nach Förderhöhe; Interviewaussagen aus den einzelnen Fallstudien folgend geht es auch um symbolisches Kapital (entsprechend ,politische Legitimierung“ bei Weimer und Vining 1999) - etwa bei der Beauftragung durch ein Parlament und um die Übernahme von Aufgaben wie etwa Öffentlichkeitsarbeit.

\section{Werte und Interessen der Auftraggeber}

Auf der normativen Ebene bedeutet dies, dass die Auftraggeber bzw. Geldgeber des ITA in ihrer Gesamtheit nicht für private oder privatwirtschaftliche Interessen stehen. Dies gilt insbesondere auch für die Trägerorganisation und wesentlichste Budgetquelle des ITA, die über das Wissenschaftsministerium finanzierte ÖAW, mit der ihr gesetzlich auferlegten Aufgabe es laut Österreichischem Bundesgesetz (ÖAW Gesetz) ist, ,,die Wissenschaft in jeder Hinsicht zu fördern“.

Sucht man nach partikularen Interessen, so finden sich: (a) anzunehmende unterschiedliche Priorisierungen unterschiedlicher ministerieller Ressorts oder auch parteipolitisch unterschiedlich besetzter Ministerien; (b) organisationale Eigeninteressen im möglichen Kräftespiel politischer Institutionen (etwa Parlament und Regierung); (c) nationale Interessen, z. B. der FFG, deren erste Aufgabe laut Forschungsförderungsgesellschaftsgesetz ,die Förderung von Forschung, Technologie, Entwicklung, Innovation und Digitalisierung (FTEI + D) zum Nutzen Österreichs“ ist; (d) Ausrichtung auf die Sozialverträglichkeit von Innovation (beispielhaft sogenannte Begleitforschung zu ethischen, rechtlichen und sozialen Aspekten neuer Technologien); und (e) die partikularen Interessen der sich als Sozialpartner gegenüber stehenden österreichischen Arbeiterkammer und der österreichischen Wirtschaftskammer. Ob sich diese zumindest vorstellbaren partikularen Interessenskonstellationen auf die Durchführung und das Ergebnis von TA-Projekten wie auch längerfristig auf die In- stitution selbst auswirken, hängt allerdings nicht nur vom konkreten Mix der Geldgeber und ihrer jeweiligen quantitativen und qualitativen Bedeutung, sondern von mehreren weiteren Faktoren ab. Im Folgenden soll insbesondere auf das Selbstverständnis der TA-PraktikerInnen in Hinblick auf client's advocacy eingegangen werden, wie auch auf die von ihnen gelebte Projektpraxis.

\section{Client's advocacy in Beratungsprojekten?}

Verstehen sich TA-PraktikerInnen am ITA als client's advocates (Bauer und Kastenhofer 2019) und handeln dementsprechend rollenkonform, oder auch nicht? Entsprechend der Rollenkonzeption in Weimer und Vining sieht sich der client's advocate vornehmlich dem Auftraggeber verpflichtet:

„He or she believes that analysts derive their legitimacy as participants in the formation of public policy from their clients, who hold elected or appointed office, or who represent organized political interests. In return for access, clients deserve professional behaviour that includes loyalty and confidentiality. Like physicians, analysts should 'do no harm' to their clients; like attorneys, they should vigorously promote their clients' interests. [...] Because analysis rarely produces definitive conclusions, analysts can emphasize the possible rather than the most likely when doing so favours their clients. [...] Clients' advocates must relegate their policy preferences to a secondary position once they make commitments to clients. Therefore, their selection of clients matters greatly.“

(Weimer und Vining 1999, S. 46 f.,

Herv. d. AutorInnen)

Bereits der erste Aspekt ist komplex: TA erhält durch die Qualität ihrer Auftraggeber zweifellos politische Legitimität. Ebenso legitimierend wirkt allerdings die wissenschaftliche Qualifikation und Qualität ihrer Arbeit, wie auch in manchen Fällen die mögliche Funktion, unterrepräsentierte Perspektiven (etwa jene auf Sozialverträglichkeit oder jene einer beteiligten Öffentlichkeit - seien es direkt Betroffene oder interessierte BürgerInnen) einzubringen. Der zweite Aspekt - Loyalität und Vertraulichkeit gegenüber dem Klienten - ist zumindest insofern limitiert, als es klare Institutsregel ist, Projektergebnisse öffentlich zugänglich zu machen. Es gibt auch keine Loyalitäts-, Vertraulichkeits- oder Schweigevereinbarungen gegenüber Auftraggebern. Im Falle langjähriger, wiederholter Kooperation kann jedoch von einer Beziehung zwischen den Kooperationspartnern ausgegangen werden, die auf dem Vertrauen basiert, dass die Beteiligten einander keinen Schaden zufügen, der das Ausmaß des wechselseitigen Nutzens übersteigt.

Geht es um die Frage, wie mit einem eventuellen Spielraum zwischen dem „Möglichen“ und dem „Wahrscheinlichen“ umgegangen wird, wird es nochmals voraussetzungsreicher. Hier, so Weimer und Vining (1999), zeige sich, ob ein Berater der Loyalität gegenüber dem Klienten oder der Loyalität gegenüber der 
subjektiv definierten „guten Sache“ folge und diesen Spielraum in die ein oder andere Richtung ausnutze. In den Interviews tauchen kaum Erzählungen von Konflikten auf, die sich aus einer solchen Diskrepanz speisen könnten und deren Bearbeitung Schlüsse in die eine oder andere Richtung zuließe. Dafür lassen sich mehrere mögliche Gründe denken: (1) das ITA und seine Auftraggeber selektieren sich wechselseitig nach Passung von Werten und Interessen; (2) die ausgewählten Beispielfälle waren gerade solche, wo es keine wesentlichen Konfliktlinien gab und sich daher Kooperation über mehrere Projekte stabilisierte; (3) es gibt zumindest vorab von beiden Kooperationspartnern eine informierte Erwartungshaltung darüber, welche Werthaltungen
Projekten erwähnt wurde. Und von dem her hat es auch [...] relativ viel Eindruck beim Auftraggeber hinterlassen“"(I II/1: 17).

Insgesamt erschließt sich das Gesamtbild einer eher limitierten client's advocacy. Ein offensichtlicher Spielraum (4) scheint vorwiegend in Bezug auf die Auswahl der adressierten Technologien sowie in Bezug auf die Auswahl behandelter Themen oder issues. In Hinblick auf einen Fokus auf das „Mögliche“ anstelle des „Wahrscheinlichen“ im Sinne von Weimer und Vining (1999) lässt sich konstatieren, dass sich eine dem vorsorgenden Paradigma verpflichtete TA immer auch für das prinzipiell mögliche und nicht nur für das wahrscheinlichste Szenario interessiert. Es gilt demnach auch einen sehr unwahrscheinlichen, jedoch poten-

\section{TA erhält durch die Qualität ihrer Auftraggeber politische Legitimität.} Ebenso legitimierend wirkt die wissenschaftliche Qualität und die mögliche Funktion, unterrepräsentierte Perspektiven einzubringen.

und Interessen das Gegenüber charakterisieren und diese sind bereits strategisch ,einkalkuliert“; (4) die Beratungsthemen sind ausreichend konkret, so dass es in ihrer Bearbeitung wenig oder gar keinen Spielraum gibt; und als letzte Alternative (5); das ITA steht für eine Reihe unterschiedlicher Werthaltungen und Interessen, die durch je unterschiedliche MitarbeiterInnen in unterschiedlichen Projekten vertreten werden.

So decken - in Bezugnahme auf (1) - die Auftraggeber die gesamte Breite möglicher Interessens- bzw. Wertespektren öffentlich-rechtlicher Institutionen ab: alle technologie-relevanten Ministerialressorts, nationale Regierung und nationales Parlament, EU Kommission und EU Parlament, FFG und FWF, Arbeiterkammer und Wirtschaftskammer sind vertreten. Der hohe und tendenziell zunehmende Anteil von Forschungsförderung durch EU-Forschungsförderprogramme lässt allerdings die Frage offen, wie die jeweilige (auf dieser Ebene ,alternativlose") interessen- und wertespezifische Ausrichtung dieser groBen Programme zu Buche schlägt. Ebenso lässt sich in Bezug zu (2) fragen, welche Interessens- oder Wertekoalitionen sich innerhalb anderer verstetigter Kooperationen ab- oder herausbilden. Es gibt in den Interviews auch Hinweise auf (3), wobei es dabei weniger um Erwartungshaltungen bezüglich Werten und Interessen im engeren Sinne, als vielmehr um Erwartungshaltungen bezüglich Perspektiven geht; dass nämlich das ITA die Perspektive auf Lebensrealitäten, Werte und Interessen von BürgerInnen, VerbraucherInnen oder ArbeitnehmerInnen ergänzend einbringen könne. So erklärt etwa ein Auftraggeber die Attraktivität des ITA für ihn damit, dass man ,auch in Europa lange suchen muss, bis man jemanden findet, der sich des Themas aus diesem [nicht-kommerziellen, Erg. d. A.] Blickwinkel angenommen hat" (I I/3: 42). Bezüglich eines anderen Projektes heißt es von Seiten des TA-Praktikers, ,,dass [dieses] als mögliche Ausnahme in den vielen industriegeleiteten oder von Industrieinteressen geleiteten ziell extrem hohen Schaden vermeiden zu helfen (entsprechend dazu die Ansätze der post-normal science und der risk governance bei Funtowicz und Ravetz 1993 bzw. Klinke und Renn 2002). Und auch wenn das ITA nicht miteinander unvereinbare Interessen vertritt (5), so folgen unterschiedliche Projekte doch unterschiedlichen Ansätzen, Wissenschaft und Politik zu verschränken, womit teils auch recht unterschiedliche Rollen für TA-PraktikerInnen einhergehen (Bauer und Kastenhofer 2019).

\section{Der Spielraum der TA}

Wo genau liegt nun jener Spielraum der TA, der sich aus der Themenwahl im Bereich des soziotechnischen Wandels ergibt? In der Pol[ITA]-Projektdatenbank wurde erhoben, welche issues durch Projekte des Instituts adressiert wurden und werden; die daraus entstandene Liste deckt alternative Perspektiven jenseits der ökonomischen (nämlich auf Gesundheit, Umwelt und Nachhaltigkeit) ebenso ab, wie die Perspektiven und Interessen unterschiedlicher Bevölkerungsgruppen (KonsumentInnen, ArbeitnehmerInnen, alternde Bevölkerung), Grundrechtsfragen (wie jene um Überwachung/Sicherheit, Privatsphäre oder Inklusion/ Gerechtigkeit/Gleichheit) oder Steuerungs- bzw. Governancefragen (im Kontext von Demokratie, Mobilisierung/Kontroversen, Transition, Technowissenschaft, und Foresight/Innovation). Daraus lässt sich - wie auch aus dem Leitbild des Instituts schließen, dass das ITA sich einerseits prinzipiell allen Themen öffentlichen Interesses im Kontext soziotechnischen Wandels widmet, in diesem Rahmen aber vielfach eine ergänzende oder ausbalancierende Rolle übernimmt:

„Das ITA betreibt interdisziplinäre Technikforschung mit drei Zielen: (1) die komplexen Wechselwirkungen von Technik und Gesellschaft aus verschiedenen Perspektiven zu verstehen, (2) die Technologieentwicklung begleitend 
zu analysieren und (3) durch Politik- und Gesellschaftsberatung zu einer sozialverträglichen Technologiepolitik beizutragen. [...] Das ITA widmet sich besonders der Analyse von unbeabsichtigten Folgen des soziotechnischen Wandels.“

(ITA 2018)

Weniger erscheint es daher als issue advocate im engeren Sinne, denn als „Einbringer“ neuer issues und Verstärker von orphan issues oder vernachlässigten Perspektiven. Die Funktion early warner bzw. early expert wurde auch in Interviews mit Kooperationspartnern häufig als Asset des Instituts genannt. In den letzten Jahren wird das Einbringen vernachlässigter Perspektiven durch den Einsatz partizipativer Methoden befördert und erhält dadurch einen neuen Charakter.

Die relativ hohe Kontinuität der Themen über die Zeit deutet darauf hin, dass diese vom Institut selbst kommen, potenziellen Auftraggebern bekannt sind und dann in Aufträgen aufgegriffen werden. Interviewaussagen verstärken diesen Eindruck. Damit besteht Abhängigkeit vordringlich darin, dass TA- bzw. Institutsthemen von Auftraggebern tatsächlich aufgegriffen werden bzw. in Forschungsförderungsprogrammen ,unterzubringen“ sind. Dies ist der Fall, wo Auftraggeberinteressen, -werte und/ oder -aufgaben mit den von Seiten des ITA adressierten Themen harmonieren. So kommen etwa die meisten Aufträge für Umwelt- und Nachhaltigkeitsthemen aus dem Umweltressort des Bundesministeriums, während das Technologieressort am häufigsten Foresight-Projekte beauftragt. Die EU-Kommission hat, vorwiegend über ihre Forschungsrahmenprogramme, die absolut häufigste Förderbeteiligung bei den Themen Demokratie und Inklusion/Gerechtigkeit, gefolgt von Technowissenschaft geschränkt öffentlich zur Diskussion gestellt werden. So zielt Horizon 2020 laut Homepage ,,at securing Europe's global competitiveness [...] as a means to drive economic growth and create jobs [...]“ (EU 2019).

Hier kann es durchaus passieren, dass TA ungewollt zu einem Technologie-Hype beiträgt, indem sie einen vorgegebenen Technologiebereich aufgreift und damit dessen (zukünftige) Wirkmächtigkeit signalisiert - unabhängig davon, mit welchen konkreten issues sie diesen dann verknüpft (Kastenhofer und Torgersen 2016).

\section{Fazit}

TA hat es - je nach Institutionalisierungsform in unterschiedlicher Weise - nicht mit einem klassischen Klienten zu tun. Ein geläufigerer und auch treffenderer Begriff ist gerade bei akademisch institutionalisierter TA jener des Auftraggebers oder Geldgebers (je nach Beauftragungsart mehr reiner Geldgeber oder mehr Auftrag- und Geldgeber). Ergänzend ist für TA auch der Begriff des Adressaten wichtig; dieser muss nicht mit dem Auftraggeber/Geldgeber übereinstimmen und übt dann keinen ökonomischen Einfluss aus, fällt aber strategisch ins Gewicht.

In Folge von Veränderungen im Wissenschaftsbetrieb spielen auch hier externe Geldquellen eine zunehmende Rolle im alltäglichen Projektbetrieb und verändern zugleich zusehends dessen Charakter. Etablierte Förderschienen wie die EU-Rahmenprogramme verändern dabei ihren Anspruch und ihre Rolle - so im ablaufenden Rahmenprogramm Horizon 2020, das mit dem deutlichen Ziel ökonomischer Konkurrenzfähigkeit das Para-

\section{Es kann passieren, dass TA ungewollt zu einem Technologie-Hype beiträgt.}

und Foresight. Der relativ häufigste Geldgeber ist die EU auch bei Überwachung/Sicherheit und Kontroversen/Mobilisierung. Gleich häufig wie die Arbeiterkammer firmiert sie als Auftraggeberin für Studien zur Privatsphäre.

$\mathrm{Zu}$ einem gewissen Grad bringen Forschungsförderungsprogramme und Auftraggeber ihrerseits Themen und Missionen ein. Bei dem nach Förderhöhe in Summe bedeutendsten Auftraggeber, den nationale Ministerien, ist dabei noch Diversität und Wahlmöglichkeit über die unterschiedlichen Ressorts gegeben. Die nach Förderhöhe zweitbedeutendste Geldquelle, die EU-Rahmenprogramme, hingegen lässt nur die Wahl zwischen unterschiedlichen Sektionen, während die zunehmend propagierten übergeordneten Missionen und die Instrumente ihrer Umsetzung (die obligatorische Beteiligung industrieller Partner, Vorgaben bezüglich der Mindestanzahl der in einem Projekt vertretenen Länder oder thematische Fokussierungen) ohne alternative Wahlmöglichkeit vorgegeben sind und auch nur sehr ein- digma Responsible Research and Innovation ausrief und damit auch die Aufgaben- und Rollendefinition von TA in Vielem vorwegnahm. Das nun folgende Rahmenprogramm Horizon Europe scheint diesen Weg der missions-orientierten Forschungsförderungspolitik weiter zu beschreiten.

Auf Basis der Analyse von empirischem Material aus dem Projekt Pol[ITA] zur Praxis der Politikberatung in der TA erwächst ein Bild, das TA nicht direkt mit der Rolle der client's advocacy von Weimer und Vining (1999) in Deckung bringt, eine Interferenz mit Werten und Interessen von Auftraggebern/ Geldgebern aber auch nicht gänzlich ausschließt. Konkret ist es das ergänzende Einbringen alternativer Ansätze (interdisziplinär, komplexitätsbewusst, nebenfolgenorientiert) und Perspektiven (insbesondere jener auf und von BürgerInnen, VerbraucherInnen, KonsumentInnen oder ArbeitnehmerInnen), durch das die TA-Praxis die Basis politischer Entscheidungen qualitativ zu erweitern sucht. 
Allgemeine Leitlinien im Umgang mit Auftraggebern/Geldgebern bestehen auf Institutsebene bereits etwa in Hinblick auf einen Ausschluss privatwirtschaftlicher Akteure aus dieser Position, einem klaren Bekenntnis zu Transparenz (Veröffentlichung aller Projektberichte) oder Abstinenz von TA-PraktikerInnen von parteipolitisch zuordenbaren Aktivitäten. Offen bleibt, ob innerhalb dieses Rahmens die Auswahl der Klienten Regeln der Selektivität (etwa Selektion nach Passung mit der eigenen Mission), Repräsentativität oder Ausgewogenheit genügen soll; wie genau die nötige Nähe und Distanz zwischen Auftraggeber und Auftragnehmer zu bemessen und wie sie zu gewährleisten ist; wie genau die nötige Nähe und Distanz zu politischen Prozessen zu operationalisieren ist; ob die gleichzeitige Beauftragung durch unterschiedliche Institutionen wie etwa Nationalrat, Ministerien und Grundlagenforschungsförderung mit institutioneller Differenzierung zu beantworten wäre; wie die ergänzende, reaktive Qualität von TA-Studien klar positioniert werden kann, ohne in den Verdacht einseitiger Interessensvertretung zu geraten; wie mit der gegenwärtig national wie international boomenden missions-orientierten Forschungsförderungspolitik umzugehen ist; und letztlich ob jenseits der Institutsebene Leitlinien guter TA-Praxis dazu beitragen könnten, die Eigenständigkeit und verlässliche Qualität von TA zu wahren und nach außen zu kommunizieren.

\section{Literatur}

Bauer, Anja; Kastenhofer, Karen (2019): Policy advice in technology assessment.

Shifting roles, principles and boundaries. In: Technological Forecasting and Social Change 139, S. 32-41.

EU - European Union (2019): What is Horizon 2020? Online verfügbar unter https://ec.europa.eu/programmes/horizon2020/what-horizon-2020, zuletzt geprüft am 29.01.2019.

Funtowicz, Silvio; Ravetz, Jeremy (1993): Science for the post-normal age. In: Futures 25 (7), S. 739-755.

Habermas, Jürgen (1963): Verwissenschaftlichte Politik und öffentliche Meinung. In: Ders. (Hg.): Technik und Wissenschaft als "Ideologie“. Frankfurt am Main: Suhrkamp, S. 120-145.

ITA - Institut für Technikfolgenabschätzung (2018): Leitbild, Fassung vom 22. 10. 2018. Online verfügbar unter https://www.oeaw.ac.at/ita/ueber-uns/ leitbild, zuletzt geprüft am 29.01.2019.

Kastenhofer, Karen et al. (2018): Beratungspraxis in der TA. In: TATuP - Zeitschrift für Technikfolgenabschätzung in Theorie und Praxis 27 (1), S. 80.

Kastenhofer, Karen; Torgersen, Helge (2016): Transhumanismus und Neuroenhancement. Technowissenschaftliche Visionen als Herausforderung für die Technikfolgenabschätzung. In: FIfF-Kommunikation 2 (16), S. 52-56.

Klinke, Andreas; Renn, Ortwin (2002): A new approach to risk evaluation and management. Risk-based, precaution-based, and discourse-based strategies. In: Risk Analysis 22 (6), S. 1071-1094.

Nentwich, Michael; Fuchs, Daniela (2018): 30 Jahre Institut für TechnikfolgenAbschätzung der Österreichischen Akademie der Wissenschaften.

In: Geistes-, sozial- und kulturwisssenschaftlicher Anzeiger der ÖAW, Bd. 153, S. 5-68.

Pielke Jr., Roger (2007): The honest broker. Making sense of science in policy and politics. Cambridge: Cambridge University Press. van Est, Rinie; Nentwich, Michael; Ganzevles, Jurgen; Krom, André (2016): Seeing technology assessment with new eyes. In: Lars Klüver, Rasmus Nielsen und Marie Jørgensen (Hg.): Policy-oriented technology assessment across Europe. London: Palgrave Macmillan, S. 18-36.

Weimer, David; Vining, Aidan (1999): Policy analysis. Concepts and practice. New Jersey: Prentice Hall.

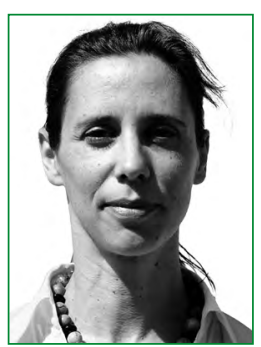

DR. KAREN KASTENHOFER

ist Wissenschafts- und Technikforscherin sowie promovierte Biologin. Sie befasst sich mit der Rekonstruktion unterschiedlicher (Techno-)Wissenschaftskulturen, der Analyse von Technikkontroversen sowie mit Governance-Modellen im Bereich der Biotechnologien. Seit 2007 ist sie Mitarbeiterin des ITA und leitete von 2016 bis 2018 das institutsinterne Projekt „Pol[ITA] - Politikberatung am ITA“.

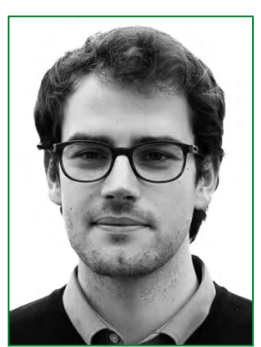

\section{LEO CAPARI}

ist Humanökologe und arbeitet seit 2013 im Bereich „Technologie und Nachhaltigkeit“ am ITA. Seine Arbeitsschwerpunkte sind Ambient Assisted Living (AAL), Umweltwissenschaften, Nachhaltigkeitsforschung und Bibliometrie/Szientometrie. Sein methodischer Interessensschwerpunkt liegt in der computergestützten sozialen Netzwerkanalyse und Netzwerkvisualisierung.

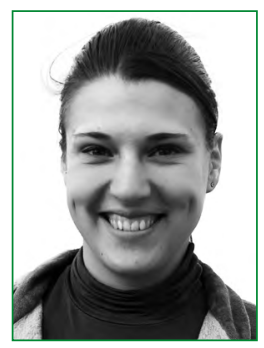

\section{DANIELA FUCHS}

ist Humanökologin und seit 2014 im Bereich „Governance kontroverser Technologien" am ITA beschäftigt. Aktuell arbeitet sie in mehreren Projekten an Fragen der Öffentlichkeitsbeteiligung im Kontext von Nanotechnologie, Neuroenhancement oder Synthetischer Biologie und zur Rolle von Computermodellbildung und Simulation in der Politikberatung.

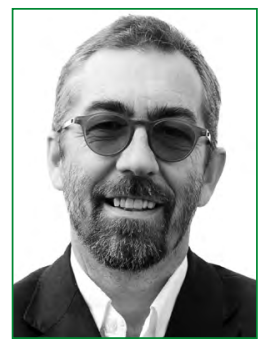

\section{DR. WALTER PEISSL}

ist promovierter Sozial- und Wirtschaftswissenschafter und begeisterter Technikfolgenabschätzer. Seit 1990 ist er stellvertretender Direktor des ITA. Schwerpunkte seiner Arbeiten liegen im Bereich neue Informationsgesellschaft, dem Schutz der Privatsphäre sowie bei methodischen Fragen der Technikfolgenabschätzung. 


\title{
Ethische Technikfolgen- abschätzung als Kartografie situativer Wertungskonflikte
}

\author{
Moralpragmatische Perspektiven zum Neutralitätsproblem
}

Sebastian Weydner-Volkmann, Centre for Security and Society, Universität Freiburg, Werthmannstr. 15, 79098 Freiburg

(sebastian.weydner-volkmann@css.uni-freiburg.de), (1) orcid.org/0000-0003-3948-4770

Der Artikel beschreibt, welches Angebot über einen moralpragmatischen Ansatz in der Technikfolgenabschätzung (TA) konkret gemacht werden kann. Ethisch argumentierende TA, so die These, lässt sich mit John Dewey als eine Kartografie situativer Wertungskonflikte begreifen. Die entstehenden „moralischen Landkarten“ zu konkreten technischen Entscheidungssituationen zielen darauf ab, den Bedarf an wissenschaftsgestützter, möglichst neutraler Beratung für den öffentlich-politischen Prozess zu ermitteln. Pragmatisch kann „Neutralität“ allerdings nicht als normative Abstinenz verstanden werden. Vielmehr soll der Ausgang von einer Rekonstruktion der normativen Konflikte genommen werden, wobei die Wertvorstellungen, die in den Entscheidungssituationen technischen Handelns jeweils relevant sind, bewusst aus unterschiedlichen Perspektiven erschlossen werden.

\section{Ethical technology assessment as cartography of situational value conflicts \\ Moral pragmatism perspectives on the problem of neutrality}

The article describes what a moral pragmatic approach in technology assessment (TA) can offer in practice. Our thesis, following John Dewey, is that argumentative ethical TA can be understood as a kind of cartography of situational value conflicts. The resulting "moral maps" aim to identify the need for scientific advice that informs public and political debate in specific decision-making situations as neutrally as possible. From a pragmatic perspective, however, "neutrality" does not entail normative abstinence. Rather, the point of departure is to re-construct the normative conflicts that are relevant in specific situations of technical decision making, deliberately approaching the values from multiple perspectives.

Keywords: Dewey, John 1859-1952; moral pragmatism; technology assessment; hermeneutics; ethics

This is an article distributed under the terms of the Creative Commons Attribution License CCBY 4.0 (https://creativecommons.org/licenses/by/4.0/)

https://doi.org/10.14512/tatup.28.1.39

Submitted: 24.10.2018. Peer reviewed. Accepted: 13. 02.2019

\section{Neutralität und Normativität im Pragmatismus}

In der wieder aufflammenden Debatte um Normativität und Neutralität plädiert Helge Torgersen (2018, S. 26) für eine Erweiterung des Selbstverständnisses von TA; die noch immer präsente „Scheu vor Ethik als Teil des Handwerkszeugs“ führt er dabei u. a. auf die Furcht zurück, eine normative Dimension gefährde den Neutralitätsanspruch der TA. Zugleich legt Armin Grunwald (2018) unter Verweis auf den amerikanischen Pragmatisten John Dewey dar, dass sich das Selbstverständnis der TA immer an demokratischen Normen orientiert, was etwa eine Ausrichtung auf soziale wie epistemische Inklusion impliziert. TA tritt hierbei in eine vorbereitende Rolle und eröffnet Räume für Kritik und staatsbürgerliche Partizipation. Doch wie kann eine „ethische Erweiterung“ der TA methodisch gelingen, will man nicht gänzlich einen wissenschaftlichen Neutralitätsanspruch aufgeben und sich partikularen politischen Positionen verschreiben? Und wie kann sich eine wissenschaftlich beratende TA über Theorien der Ethik ganz ausdrücklich der Wertsphäre zuwenden, ohne zugleich der undemokratischen Versuchung zu erliegen, dem politischen Prozess die jeweils ,ethisch gebotene" Entscheidung konkret vorzugeben?

\section{Deweys Pragmatismus - einige Grundzüge}

Folgt man Grunwalds Hinweis auf Dewey, so lässt sich aus pragmatischer ${ }^{1}$ Sicht zunächst festhalten, dass Normativität und Neutralität keineswegs als gegensätzliche Pole aufgefasst, sondern als eigenständige Problembereiche begriffen werden sollten. Denn zunächst vollzieht sich jede wissenschaftliche Untersuchung innerhalb von Wertkontexten: Wir bewerten, welche Forschungsfrage wichtig genug ist, verfolgt $\mathrm{zu}$ werden, welches Problem

1 „Pragmatisch“ soll hier und im Folgenden nicht alltagssprachlich verstanden werden, sondern als Bezeichnung für den epistemologischen Ansatz im klassischen amerikanischen Pragmatismus, speziell jenem Deweys. 
wir adressieren und bestenfalls lösen möchten - und welches eben nicht. Mit einer Spitze gegen Descartes schreibt schon der Begründer des Pragmatismus, Charles S. Peirce (1975, S. 70 f.), einen Zweifel bloß zu benennen, genüge nicht. Vielmehr bedürfe es eines ,lebendigen Zweifels“, der uns in einem konkreten Kontext zur Nachforschung drängt und motiviert - und erst hieraus werden Untersuchung und Ergebnis wirklich verständlich.

Im Pragmatismus werden Theorien und Begriffe dabei als Instrumente des Denkens für das Handeln aufgefasst. Deweys Wendung dieses Grundgedankens zielt sehr umfassend auf eine Bewältigung problematischer Situationen ab (Noetzel 2009). Letztlich ersetzt er den Begriff „Wissen“ in seinem emphatischen und universal-gültigen Sinne durch das Konzept der prak-
Ethos der Selbstregulierung. Folgt man seiner Rückbindung von Erkenntnisprozessen an ein umfassend verstandenes Erleben der Konsequenzen im sozialen Kontext, so scheint es zudem recht künstlich, unser Wissen „normativ steril“ halten zu wollen. Vielmehr gilt es, normative Dimensionen - auch in der TA - bewusst und reflektiert einzubinden.

Wertkonzepte entstehen dabei, wie Dewey (1988, S. 219) schreibt, weder aus dem apriorischen Nichts heraus, noch werden sie uns als Gebote offenbart. Als stabilisierte, ehemals aktiv vollzogene Wertungen sind sie eingebunden in soziale Handlungskontexte; sie verweisen auf vergangene Problemsituationen und versuchte Lösungsstrategien. Und diese gilt es, etwa auch mit Blick auf neue Technologien, immer wieder neu zu reflektieren.

\section{Folgt man Dewey, so scheint es recht künstlich, unser Wissen „,normativ steril“ halten zu wollen.}

tischen Gültigkeit: Begriffe und Theorien „funktionieren“ und bewähren sich im Umgang mit der dinglichen wie auch sozialen Umwelt, weil die tatsächlich erlebten Konsequenzen des Handelns die Erwartungen stimmig einlösen. Damit zusammen hängt auch sein durchweg fallibilistischer Wahrheitsbegriff: Alle Urteile und Begriffe können grundsätzlich an neuen Erfahrungen scheitern. Entsprechend kann ein lebendiger Zweifel zwar vorläufig befriedet, aber nie letztgültig ausgeräumt werden (Dewey 1982, S. 16).

Solche Prozesse des Erlebens begreift Dewey einerseits als im sozialen Austausch verankert, nämlich über kommunikativ stabilisierte Überzeugungen (settled beliefs), und andererseits als verbürgt über die Erfahrung der Konsequenzen unseres Handelns (Weydner-Volkmann 2018, S. 60 f.). Hier können die settled beliefs auch in Widersprüche geraten und somit scheitern. Es ist insbesondere das Erleben eines situativen Scheiterns, eines „Problems“, das uns zum systematischen Nachdenken und Nachforschen anregt. Solche Probleme werden nicht zuletzt durch die fortwährenden technischen Umwälzungen provoziert, die Dewey $(* 1859 ; \dagger 1952)$ selbst in drastischer Weise erlebt hat, als die USA zunächst eine beschleunigte Industrialisierung und sodann als erste Gesellschaft den Schritt ins Atomzeitalter vollzogen (Hickman 2001, S. 2 f.).

\section{Neutralität als Ethos der Distanz zu einseitigen Wertungen}

Ein Ansatz, der wissenschaftliche Erkenntnis derart eng in soziokulturelles Handeln und Erleben einwebt, bietet dabei schlicht keinen Raum für eine normativ isolierte, ,wertneutrale“ Theoriebildung. Vielmehr verweist für Dewey (1978, S. 196198) schon die Bereitschaft, Untersuchungen methodisch und ergebnisoffen zu vollziehen, statt Denkgewohnheiten, Assoziationen oder Präferenzen zu folgen, auf eine bewusst vollzogene Regulierung der eigenen Denkprozesse - letztlich also auf ein
Nach Dewey verfehlen ethische Ansätze, die über einen feststehenden, universalgültigen Wert oder letzten Zweck argumentieren, ${ }^{2}$ im Kern ihre eigentliche Aufgabe, weil sie die im strengen Sinn moralisch strittigen Entscheidungssituationen nicht adäquat adressieren können. Moralische Konflikte, insbesondere auch die in der TA häufig auftretenden Zwickmühlen, werden in solchen Ethiken letztlich als ein Randphänomen begriffen, als eine Art Dysfunktion des moralischen Wissens: Je größer die Einsicht in das je angenommene letzte Wert- oder Vernunftprinzip ist, desto eindeutiger können Wertkonflikte durch Subsumption unter dieses aufgelöst und ,wegerklärt“ werden (Weydner-Volkmann 2018, S. 75-77).

Eine produktive Aufarbeitung für eine vielseitig informierte politische Entscheidungsfindung, wie sie in der TA intendiert ist, wäre so kaum zu leisten, müssten sich die jeweils relevanten konfligierenden Wertkonzepte doch auf einen gemeinsamen Nenner bringen lassen. Bei der Entwicklung und dem Einsatz selbstlernender Videoüberwachung könnten dies etwa Sicherheitsbedürfnisse (z. B. Schutz vor terroristischen Angriffen durch kostengünstige, automatisierte Detektion verdächtigen Verhaltens) und Freiheitsrechte sein (z. B. Schutz vor der Erstellung von Bewegungs- und Persönlichkeitsprofilen). Um einer drohenden Einseitigkeit zu begegnen, böte sich zwar eine Nebeneinanderstellung verschiedener ethischer TA-Untersuchungen mit je eigenen Schwerpunkten an. Die vorbereitende Erarbeitung gangbarer

2 Dewey und Tufts (1978) setzen sich recht holzschnittartig mit je einem Vertreter der drei großen Ethiktraditionen auseinander: über Kant wird die Pflichtethik, über Mill der Utilitarismus und über Aristoteles die Tugendethik verhandelt. Trotz der konsequenten Zurückweisung universeller und letztgültiger Ansprüche sollen derartige Ansätze aber keineswegs verworfen werden. Vielmehr stellt Dewey auch den jeweiligen Eigenwert dieser Ansätze für die moralische Reflexion von Entscheidungssituationen heraus. Im Moralpragmatismus sollen diese zum Teil gegenläufigen Formen ethischer Argumentation bestehen bleiben und zu einer multi-perspektivischen Theorie integriert werden (Fesmire 2014, S. 122). 
politischer Kompromisse droht durch die Gegenüberstellung je nicht weiter verhandelbarer normativer Prinzipien jedoch erschwert zu werden und wäre in jedem Fall methodisch weiterhin klärungsbedürftig.

Demgegenüber rückt ein moralpragmatischer Ansatz die Wertungskonflikte selbst ins Zentrum der Untersuchung; sie bilden als situativ erlebtes Problem den Ausgangspunkt der Überlegungen. Dass der Prozess der Nachforschung sich letztlich nicht ,wertneutral“" vollziehen kann, sondern immer schon in normative Horizonte ein- und an sie rückgebunden ist, heißt dabei keineswegs, dass wir unseren jeweiligen Wertvorstellungen ausgeliefert wären. Zwar ist jede Entscheidungssituation durch unsere Wertungen geprägt und kann prinzipiell auch immer moralisch relevant werden, allerdings liegt Dewey zufolge nur dann eine genuin moralische Handlungssituation vor, wenn wir uns eines Wertungskonflikts auch wirklich bewusstwerden (Dewey und Tufts 1978, S. 194). Das routiniert-habituelle Handeln stockt, weil wir uns zwischen verschiedenen, sich gegenseitig ausschließenden Zwecken für unser Handeln entscheiden müssen - etwa, weil wir kostengünstigen Schutz vor terroristischen Angriffen ebenso erstreben, wie wir zu vermeiden suchen, dass die massenhafte Erstellung von Bewegungsprofilen ermöglicht wird. Und erst das Erleben einer konfliktbehafteten Entscheidungssituation macht moralische Deliberation - und damit auch den Rückgriff auf ethische Theorien - überhaupt nötig. In dem Für und Wider aus gegenläufigen, auch fremden Perspektiven sieht der Deweysche Pragmatismus das kritische Poten-

\section{Moralische Landkarten technischen Handelns}

Wenn ein moralpragmatischer Ansatz in der TA also nicht darauf abzielen kann, zu entscheiden, „was ethisch geboten ist“, worin besteht dann konkret das Angebot? Für Dewey (1984, S. 323 f.) geht es gerade auch im Umgang mit technischem Wandel letztlich darum, adäquate intellektuelle Werkzeuge für eine informierte politische Diskussion und Entscheidungsfindung bereitzustellen. Hier schließt fast nahtlos seine politische Philosophie mit einem emphatischen Begriff demokratischer Öffentlichkeit an: Der Ethos einer Distanz zu den eigenen Wertungen manifestiert sich auch hier nicht in einer normativen Enthaltsamkeit, sondern in der Inklusion widerstreitender Perspektiven (Fesmire 2014, S. 154 f.). Das Aufeinandertreffen verschiedener Wertungen lässt sich dabei als aufzuarbeitendes Problem, zugleich aber auch als epistemische Bereicherung des normativen Entscheidungshorizonts begreifen.

Welchen Wertvorstellungen wir am Ende den Vorrang gewähren wollen, bleibt hierbei letztlich immer eine politische Entscheidung; ein moralpragmatischer Ansatz zielt jedoch darauf $\mathrm{ab}$, eine solche Entscheidungsfindung so reflektiert wie möglich zu gestalten. Hierfür benötigen wir Konzepte, die es vermögen, Entscheidungsprobleme aus verschiedenen Perspektiven zu beleuchten und sie in ihrer normativen Dimension verständlich zu machen. Technischer Wandel fordert diese Konzepte allerdings immer wieder neu heraus. Schon Mitte der 1920er-Jahre beklagt

Wir benötigen Konzepte, die es vermögen, Entscheidungsprobleme aus verschiedenen Perspektiven zu beleuchten und sie in ihrer normativen Dimension verständlich zu machen.

zial einer Ethik - nicht im Sinne eines Überwindens normativer Voreingenommenheit oder einer einseitigen Auflösung des Konflikts über letzte normative Prinzipien, sondern im möglichst umfassend reflektierenden Abwägen der Entscheidungssituation, das ein distanzierteres Verhältnis zu den eigenen habitualisierten Wertungen ermöglicht.

Die Identifizierung und Klärung der je relevanten Wertkonzepte ist hierbei eine der zentralen ethischen Aufgaben. Deweys Moralpragmatismus steht dabei kontextualistischen Ansätzen der angewandten Ethik nahe, insofern diese auf eine Letztbegründung verzichten und über eine möglichst breite Verankerung in situationsrelevanten und weithin geteilten Wertkonzepten argumentieren. Moralpragmatisch wird dies aber explizit aus verschiedenen Perspektiven vollzogen, die in ihrem Eigenrecht durchaus auch gegeneinanderstehen können und sollen - erst so wird der Entscheidungskonflikt im Bereich technischen Handelns wirklich einsichtig. Ihn zu lösen kann hingegen gerade nicht Aufgabe einer moralpragmatischen TA Deweyscher Prägung sein.
Dewey (1984, S. 323 f.) dabei, dass wir zwar über nie zuvor gekannte Möglichkeiten der Kommunikation verfügen, es uns aber zugleich schmerzlich an Konzepten fehle, die uns erlauben, die Probleme des technischen Wandels in der Öffentlichkeit sinnvoll zu diskutieren. Vor diesem Hintergrund sind partizipative Ansätze der TA moralpragmatisch gesehen durchweg zu begrüßen.

Und doch verweist der beschriebene Mangel an ,intellektuellen Werkzeugen“ für eine gelingende TA noch auf einen weiteren Aspekt. Denn im Kern bedarf es hierbei immer auch einer im weiteren Sinne hermeneutischen Klärung der moralischen Konfliktsituation (Weydner-Volkmann 2018, S. 90-92). Dewey gebraucht für diesen Gedanken bisweilen die Metapher der Kartografie, etwa im Sinne einer verlässlicheren Orientierung über zweckmäßig erzeugte Landkarten, oder auch des systematischen Auslotens von Untiefen zur Erzeugung von Seekarten (Fesmire 2014, S. 53-59). Angepasst an die moralische Situation müssen solche Karten dabei immer selektive Schwerpunkte setzen; sie sind also niemals nur eine passiv-wiedergebende Beschrei- 
bung, sondern müssen als auf einen Zweck hin aktiv-konstruierend begriffen werden - als Re-Konstruktion, die hilfreich, aber eben auch untauglich und irreführend sein kann (Lekan 2003, S. 3 ff.). Ziel ist dabei eine Transformation des Problemerlebens, das heißt ein vertieftes Verständnis der konfliktbeladenen Entscheidungssituation (Hildebrand 2008, S. 53-57).

Insofern kann das Ausarbeiten einer solchen Karte letztlich im weiteren Sinne als eine hermeneutische Selbstverständigung verstanden werden, die als Teil einer TA auch ein Beratungsangebot für politische Debatten darstellen kann. Einer so verstandenen, moralpragmatisch argumentierenden TA ginge es letzt-

\section{Über den Rückgriff auf moralische Landkarten kann

$$
\begin{gathered}
\text { die TA vermeiden, als objektiver } \\
\text { „Problemlöser“ aufzutreten. }
\end{gathered}
$$

lich um eine systematische Orientierung technischen Handelns hinsichtlich der jeweils relevanten normativen Implikationen. Über sie soll eine möglichst umfassende, methodisch geklärte Informierung politischer Prozesse aus unterschiedlich wertenden Perspektiven geleistet werden - wodurch sich zum einen hervorragend an Überlegungen zur argumentativen TA anschlieBen (van Est und Brom 2012, S. 314), zum anderen aber auch auf den Vorschlag einer hermeneutischen Wende in der TA antworten lässt (Grunwald 2015, S. 66).

Über den Rückgriff auf derartige moralische Landkarten kann die TA zudem vermeiden, als objektiver „Problemlöser“ aufzutreten - was ja letztlich schon an legitimatorischen Erfordernissen scheitern würde (Technokratieproblem). Zugleich impliziert dies auch den Anspruch, nicht als Akzeptanzbeschaffer einer bestimmten politischen Option zu dienen, denn die angestrebte Multi-Perspektivität soll es ja gerade ermöglichen, die wertebezogenen settled beliefs auch des eigenen Lagers zu hinterfragen und umfassender zu reflektieren.

Als intellektuelles Werkzeug adressieren moralische Landkarten dabei konkrete Entscheidungssituationen und fungieren mit Blick auf präferierte Optionen gewissermaßen als Spiegel der eigenen Wertvorstellungen: Jede Entscheidung impliziert eine Reihe von Priorisierungen, von Wertungen über den Vorrang von Wertvorstellungen untereinander. Solche Wertungen über Werte können moralpragmatisch zwar nicht als ,ethisch richtig“ oder „ethisch falsch“ beurteilt werden, aber sie implizieren doch eine ganze Menge über den normativen Charakter unserer selbst und unserer politischen Gemeinschaft. Die normative Frage danach, welchen Charakter wir unserer Gesellschaft geben wollen, kann entsprechend als orientierende Leitfrage für den politischen Entscheidungsprozess dienen, ohne die Entscheidung selbst schon vorwegzunehmen.

\section{Situative Ausarbeitung und Fallibilität}

Für den Prozess der Ausarbeitung einer moralischen Landkarte impliziert der moralpragmatische Fokus auf situative Wertungskonflikte eine Reihe zu berücksichtigender Aspekte. Zunächst dürfte mit Blick auf die enge Einbindung in sowie die konsequente Rückbindung an Entscheidungskontexte recht deutlich sein, dass ein Fokus auf Techniken und Gerätschaften wenig vielversprechend ist - die relevanten Wertungen etwa zur selbstlernenden Videoüberwachung werden je nach Einsatzkontext unterschiedlich ausfallen.

Andererseits geht die situative Ein- und Rückbindung auch nicht in einer Einzelfallanalyse auf: Eine Landkarte soll ja nicht für jeden Gebrauch neu gezeichnet werden, sondern für eine Reihe von Fällen ähnlicher Art dienlich sein. Hierzu werden moralische Landkarten thematisch gerichtet konzipiert (Weydner-Volkmann 2018, S. 110 f.; Waldenfels 2013, S. 57-68): Als Teil einer TA werden sie erstellt, um für konfliktbehaftete Entscheidungen ganz bewusst bestimmte Aspekte als relevant in den Vordergrund zu heben und um andere bewusst aus dem Blickfeld zu rücken, weil sie nicht als wesentlicher Teil der situativen Entscheidung begriffen werden. Je nach gesetztem Thema ergeben sich so typische, das heißt für ähnliche Entscheidungssituationen wiederkehrende Wertungskonflikte. Angenommen, Thema sei der Einsatz selbstlernender Videoüberwachung als Teil von Sicherheitskontrollen an Flughäfen, so rückte für die Kontrollen zunächst das Wertkonzept der Schutz vor Angriffen in den Vordergrund, bei relevanten konfligierenden Wertungen u. a. der Schutz vor Eingriffen in die Privatheit. Fragen zur gerechten Bezahlung des Kontrollpersonals ließen sich für dieses Thema hingegen vernachlässigen.

Zur Vorbereitung der hermeneutischen Klärung der Wertkonzepte bietet sich dabei die Ausarbeitung von Typologien an, also etwa wiederkehrende Untertypen von Eingriffen in die Privatheit zu identifizieren und weiter auszudifferenzieren. Abbildung 1 zeigt einen Teil eines solchen Prozesses. Ähnliche Verfahren finden in der TA ohnehin häufig Anwendung, moralpragmatisch wird dabei jedoch keine allgemeine Klärung von Wertkonzepten angestrebt, sondern eine im situativen Kontext verortete Klärung. So lassen sich Wertkonzepte über mehrere Ebenen bis hin zu beobachtbaren Sachverhalten ausdifferenzieren: Werden bei den Kontrollen biometrische Daten erhoben oder nicht? Bleiben die Daten gespeichert und erlauben so die Wiedererkennung von Personen?

Die hierauf aufbauenden moralischen Landkarten können aber immer nur unter Vorbehalt auf andere Situationen übertragen werden - für andere Formen von Kontrollprozessen (etwa Grenzkontrollen) bedarf es entsprechend einer gewissenhaften Prüfung, ob die in der Karte vollzogene situative Ausdeutung für ein verändertes Erkenntnisinteresse oder für zeitlich spätere Entscheidungskontexte noch angemessen ist. Zudem wird klar, inwiefern die Ausarbeitung moralischer Landkarten in der TA auch scheitern kann. Denn träten in einer öffentlichen Debatte, etwa zum Einsatz selbstlernender Videoüberwachung, thema- 


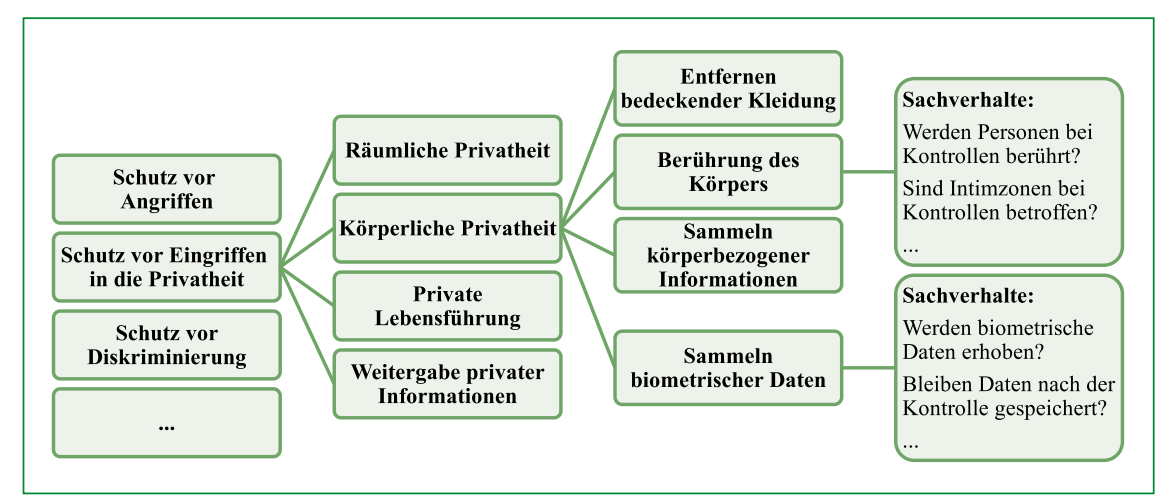

Abb.1: Situative Ausdifferenzierung relevanter Wertkonzepte bei Sicherheitskontrollen.

Quelle: Eigene Darstellung

tisch relevante Wertkonzepte zutage, die in den erstellten Typologien nicht berücksichtigt wurden, so erwiese sich die Landkarte als zumindest ergänzungsbedürftig, jedenfalls in dieser Form als untauglich.

Es bietet sich daher an, die Landkarten in Auseinandersetzung mit der Empirie auszuarbeiten - etwa über die Analyse politischer Debatten oder über geeignete partizipative Verfahren (Mader et al. stellen in diesem TATuP-Thema eine dezidiert pluralistisch ausgerichtete Methode zur Darstellung normativer Orientierungen vor). Um als intellektuelles Werkzeug dienen zu können, bedarf es zudem einer hermeneutischen Klärung der situativ ausdifferenzierten Begriffe, die verständlich macht, wie diese mit den übergeordneten Konzepten zusammenhängen und sich kulturell begründen. Auch hier können Ausarbeitungen scheitern, etwa wenn die Darstellung historisch unangemessen ist oder kein vertieftes Verständnis der Entscheidungssituation erlaubt.

Entsprechend bilden moralische Landkarten keine normativen Großtheorien, sondern verstricken sich in situative Eigenheiten technischen Handelns, deren Aufarbeitung bisweilen recht kleinteilig geraten kann. Immerhin konnte gezeigt werden, dass es eine enge Einbindung in die Entscheidungssituation erlauben kann, an moralische Landkarten konsistent eine operationalisierte Bewertung aus mehreren Perspektiven anzuschließen (Weydner-Volkmann 2018, S. 233-270). Für Innovationsbereiche, bei denen der technische Wandel halbwegs gut abzuschätzen ist, lassen sich so, wie von Grunwald (1999, S. 75) auch für ethische Ansätze eingefordert, qualitativ vergleichend „Planungsgrößen“ als Grundlage für politische Entscheidungsprozesse erarbeiten.

Beispielsweise werden sich durch den Einsatz selbstlernender Videoüberwachung bestimmte Sachverhalte bei Sicherheitskontrollen an Flughäfen anders darstellen - etwa, weil nun für alle Passagiere biometrische Daten erhoben werden. Dadurch verschärft sich der Eingriff in den korrespondierenden Aspekt von Privatheit. Zugleich mag es aber auch möglich sein, dass dadurch die Zahl intensiver Nachkontrollen verringert und somit ein anderer Wertungskonflikt entschärft werden kann. Für die politische Debatte lässt sich so darstellen, welche Wertungen über Werte die Entscheidung für bzw. gegen den Technikeinsatz impliziert; über die hermeneutische Komponente der moralischen Landkarte ließe sich zudem durchgängig verstehen, worin hierbei jeweils die spezifische ethische Relevanz liegt.

Schwieriger gestaltet sich die Ausarbeitung der Karte, sofern sich Wertungskonflikte erst zu einem späten Zeitpunkt abschätzen lassen, wenn Gestaltungsspielräume kaum mehr vorhanden sind (Collingridge-Dilemma). Solche Grundprobleme der TA lassen sich über die hermeneutische Komponente moralischer Landkarten zwar adressieren, indem man versucht, von einer Prognostik auf eine Ausdeutung der mit dem Technikeinsatz verbundenen Hoffnungen und Ängste zu wechseln (Grunwald 2015, S. 66 ff.). Lösen lässt sich das epistemische Grundproblem unsicherer Zukünfte freilich auch über einen moralpragmatischen Ansatz nicht.

Eine moralpragmatisch erweiterte TA, so lässt sich abschlieBend sagen, kann jedoch dabei helfen, bewusst ein Ethos der Distanz zu je eigenen, einseitigen Wertungen einzunehmen nicht als normative Abstinenz, sondern durch eine methodisch geklärte Offenheit für widerstreitende Wertungen. Über moralische Landkarten lassen sich dabei intellektuelle Werkzeuge für politische Entscheidungsprozesse bereitstellen, ohne dabei schon vorwegzunehmen, was ,ethisch geboten“ sei.

Dies verstellt indes den Weg zu einem Selbstverständnis der TA im Sinne einer programmatisch-politischen Gegenrolle, wie sie aktuell vorgeschlagen wird (Delvenne und Parotte 2019). Als derartiges Selbstbehauptungsprojekt gegenüber einem konstitutiven Anderen, einem politischen Gegner, von dem sich ein politisches Wir der TA abgrenzen lasse, würde sich die TA letztlich dem entziehen, was sich mit Dewey (1978, S. 208) gewissermaßen als Verantwortung für die eigenen Reflexionsprozesse begreifen lässt und was Hans-Georg Gadamer einst so formulierte: „Wir müssen endlich wieder lernen, wie man ein richtiges Gespräch führt. Das ist eine sehr verantwortungsvolle Aufgabe für die Philosophie. Ein Gespräch setzt voraus, dass der andere Recht haben könnte“ (Sturm 2000, S. 305).

\section{Literatur}

Delvenne, Pierre; Parotte, Céline (2019): Breaking the myth of neutrality. Technology assessment has politics, technology assessment as politics. In: Technological Forecasting and Social Change 139, S. 64-72.

Dewey, John (1978): The Middle Works Volume 6: 1910-1911. Carbondale (Ill.): Southern Illinois University Press.

Dewey, John (1982): The Later Works Volume 12: 1938. Carbondale (Ill.):

Southern Illinois University Press.

Dewey, John (1984): The Later Works Volume 2: 1925-1927. Carbondale (IIl.): Southern Illinois University Press. 
Dewey, John (1988): The Later Works Volume 13: 1938-1939. Carbondale (Ill.): Southern Illinois University Press.

Dewey, John; Tufts, James (1978): The Middle Works Volume 5: 1908. Carbondale

(IIl.): Southern Illinois University Press.

Fesmire, Steven (2014): Dewey. New York: Routledge.

Grunwald, Armin (1999): TA-Verständnis in der Philosophie. In: Stephan Bröchler, Georg Simonis und Karsten Sundermann (Hg.): Handbuch Technikfolgenabschätzung. Berlin: edition sigma, S. 73-81.

Grunwald, Armin (2015): Die hermeneutische Erweiterung der Technikfolgenabschätzung. In: TATuP - Zeitschrift für Technikfolgenabschätzung in Theorie und Praxis 24 (2), S. 65-69.

Grunwald, Armin (2018): Technikfolgenabschätzung und Demokratie. Notwendige oder kontingente Verbindung? In: TATuP - Zeitschrift für Technikfolgenabschätzung in Theorie und Praxis 27 (1), S. 40-45. D0I: 10.14512/tatup.27.1.40. Hickman, Larry (2001): Philosophical tools for technological culture. Putting pragmatism to work. Bloomington: Indiana University Press.

Hildebrand, David (2008): Dewey. A Beginner's Guide. Oxford: Oneworld.

Lekan, Todd (2003): Making morality. Pragmatist reconstruction in ethical theory. Nashville: Vanderbilt University Press.

Noetzel, Thomas (2009): Die politische Theorie des Pragmatismus. John Dewey. In: André Brodocz und Gary Schaal (Hg.): Politische Theorien der Gegenwart I. Eine Einführung. Opladen: Barbara Budrich, S. 149-75.

Peirce, Charles (1975): Was heißt Pragmatismus? In: Ekkehard Martens (Hg.): Texte der Philosophie des Pragmatismus. Stuttgart: Reclam, S. 99-127.

Sturm, Thomas (2000): „Rituale sind wichtig“. Hans-Georg Gadamer über Chancen und Grenzen der Philosophie. In: Der Spiegel 8/2000, S. 305.
Torgersen, Helge (2018): Die verborgene vierte Dimension. Normative Reflexion als Erweiterung der Theorie der Technikfolgenabschätzung. In: TATuP Zeitschrift für Technikfolgenabschätzung in Theorie und Praxis 27 (1), S. 21-27. DOI: 10.14512/tatup.27.1.21.

van Est, Rinie; Brom, Frans (2012): Technology assessment, analytic and democratic practice. In: Ruth Chadwick, Dan Callahan und Peter Singer ( $\mathrm{Hg}$.): Encyclopedia of applied ethics. London: Academic Press, S. 306-320. Waldenfels, Bernhard (2013): Ordnung im Zwielicht. Paderborn: Fink. Weydner-Volkmann, Sebastian (2018): Moralische Landkarten der Sicherheit. Ein Framework zur hermeneutisch-ethischen Bewertung von Fluggastkontrollen im Anschluss an John Dewey. Baden-Baden: Ergon.

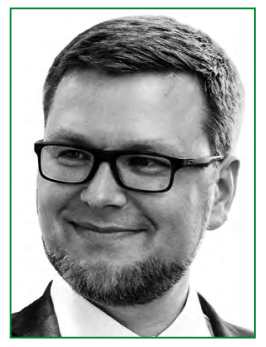
forscht zu Technikphilosophie, Demokratietheorie und Angewandter Ethik mit Schwerpunkt in der Sicherheitsforschung. Seit 2012 arbeitet er am Centre for Security and Society und am HusserlArchiv der Universität Freiburg. Zuletzt entwickelte er ein Framework zur ethischen Bewertung von Fluggastkontrollen.

\section{DIE ZUKUNFT DES WIRTSCHAFTENS HAT BEGONNEN!}

\section{Die Zeitschrift Ökologisches Wirtschaften} schließt die Lücke zwischen Theorie und Praxis einer nachhaltigen Gestaltung der Wirtschaft.
Jetzt vergünstigtes Probeabo sichern!

2 Ausgaben für nur 13,30 Euro inkl. Versand im gesamten Jahr 2019 statt 19,- Euro. abo@oekom.de

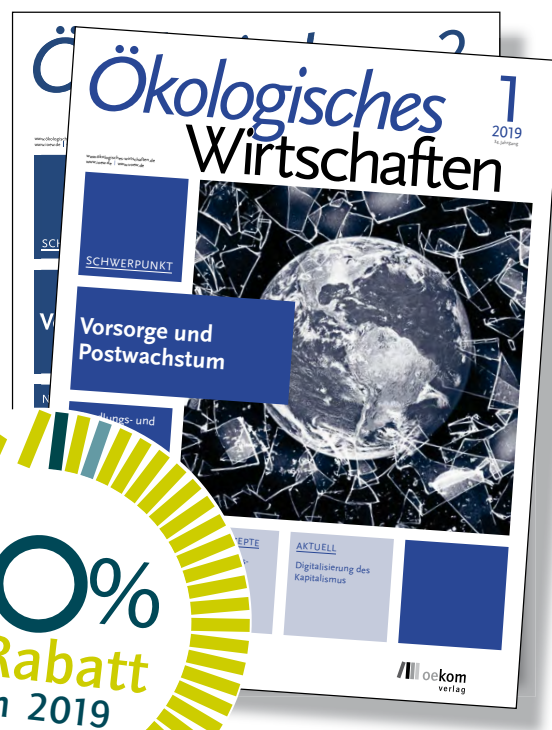

in 2019

\section{/IIl oekom}

www.oekologisches-wirtschaften.de 


\title{
Indikatorenarbeit
}

\author{
Kontextneutralisierende und kontextoffene Strategien \\ in der Analyse komplexer Probleme
}

\author{
Stefan Böschen, Human Technology Center (HumTec) RWTH Aachen University, Theaterplatz 14, 52062 Aachen \\ (stefan.boeschen@humtec.rwth-aachen.de), (1) orcid.org/0000-0003-0519-5030 \\ Mahshid Sotoudeh, Institut für Technikfolgen-Abschätzung (ITA-ÖAW) (Mahshid.Sotoudeh@oeaw.ac.at) \\ Volker Stelzer, Institut für Technikfolgenabschätzung und Systemanalyse (ITAS), Karlsruher Institut für Technologie (KIT) (volker.stelzer@kit.edu)
}

Die Analyse komplexer Probleme, unter anderem mittels Indikatoren, gehört zum Alltag der Technikfolgenabschätzung (TA). Indikatorenarbeit verdeutlicht, dass die Auswahl von Indikatoren, trotz genereller Regeln, auf akteursabhängigen Entscheidungen beruht. Die These des Artikels lautet, dass TA kontextneutralisierende wie kontextoffene Analysestrategien nutzt. Die Analyse von Indikatorenarbeit an einem Beispiel im Feld der Nachhaltigkeitsanalyse zeigt, wie die Spannung zwischen diesen beiden Analysestrategien in der Indikatorenarbeit durch Verfahrensregeln transparent zu machen ist. Normative Transparenz kann durch reflektierte Indikatorenarbeit in der TA sichergestellt werden.

\section{Indicator work}

Context-neutralizing and context-open strategies in the analysis of complex problems

The analysis of complex problems, e. g., using indicators, is part of technology assessment (TA) practice. The term "indicator work" illustrates that the selection of indicators is, besides general rules, based on individual decisions. The hypothesis is that TA uses two analytical strategies: context-neutralizing and context-open variants. Looking at an example of sustainability analysis in TA, we will show how the tension between the two strategies can be made transparent by procedural norms in indicator work. Normative transparency can be ensured by reflective indicator work in TA.

Keywords: indicators, sustainable development, options for action, valuation, complex problems

This is an article distributed under the terms of the Creative Commons Attribution License CCBY 4.0 (https://creativecommons.org/licenses/by/4.0/)

https://doi.org/10.14512/tatup.28.1.45

Submitted: 22. 10.2018. Peer reviewed. Accepted: 13.02.2019

\section{Einleitung}

Die Analyse komplexer Probleme gehört zum Alltagsgeschäft von Technikfolgenabschätzung (TA). Jede für TA bedeutsame Frage bezieht sich auf Probleme, für die gesellschaftlicher Entscheidungsbedarf schon besteht bzw. entstehen kann. Komplexe Probleme zu analysieren, muss jedoch methodologisch als ein anspruchsvolles Alltagsgeschäft angesehen werden. Denn die damit verbundene Auswahl und Spezifizierung von Indikatoren (Indikatorenarbeit) verlangt eine reflektierte Strategie, um komplexen Problemen aufgrund normativer Voreinstellungen nicht eine unzutreffende Gestalt zu geben. Dass hier eine für die TA herausfordernde Reflexionsaufgabe besteht, zeigt sich an der typischerweise in der TA genutzten Unterscheidung zwischen Technikfolgenanalyse und Technikbewertung. Denn diese suggeriert eine Trennung von zwei Arbeitsschritten innerhalb der TA, deren Voraussetzung nicht immer gegeben, aber gleichwohl normativ relevant ist. Dagegen vertreten wir die These, dass in der TA zwei kontrastierende Strategien der Analyse von komplexen Problemen angewandt werden: kontextneutralisierende im Gegensatz zu kontextoffenen.

Vor diesem Hintergrund gliedert sich der Aufsatz in vier Teile. Erstens werden kontextneutralisierende und kontextoffene Formen der TA-Analyse idealtypisch aufgezeigt und auf dieser Grundlage Indikatorenarbeit definiert. Zweitens werden Problemkreise der Indikatorenarbeit herausgestellt. In einem dritten Schritt stellen wir die konkreten Herausforderungen der Indikatorenarbeit an einem TA-Projekt vor, die sich in der Fülle der Auswahlentscheidungen zeigt. Anschließend werden die Einsichten ausgewertet und ein Ausblick auf künftige Perspektiven gegeben.

\section{Analysestrategien in der TA: kontextneutralisierend - kontextoffen}

Für vielschichtige Sachverhalte der Technologie- und Innovationsentwicklung erzeugt TA entscheidungsrelevantes Wissen. Um nicht unter den Verdacht politischer Vorteilnahme oder des 
Verfolgens von Partialinteressen zu geraten, sollte dieses Wissen in besonderer Weise wissenschaftliche Rationalität verkörpern (Grunwald 1999). Das gelang am überzeugendsten mittels möglichst standardisierter Wissensmodelle und Quantifizierung der Nebenfolgen durch ausgesuchte Verfahren, wie z.B. die Kosten-Nutzen-Analyse (Bröchler et al. 1999). Diese bilden auch weiterhin das methodische Rückgrat der TA neben neuerer Ansätze der konstruktiven TA, der partizipativen TA oder der antizipativen TA.

So kamen mit der Zeit andere Fragestellungen hinzu, die weniger ,technikinduziert“ als vielmehr ,problembezogen“ waren (Bechmann 1993). Die Debatte um Nachhaltige Entwicklung ist die Integration von Umweltkomplexität von großer Bedeutung ist und enge Systemgrenzen aufgebrochen werden sollen, etwa in der Medizin, der Pflege, der Bildung oder auch der Seelsorge. Deshalb kann es ,,in kontextoffenen Operationen nicht mehr allein darum gehen, eine systeminterne Operation durchzuführen und alles weitere der Umwelt zu überlassen, vielmehr muss die Bearbeitung der Umwelt selbst noch in die interne Operation aufgenommen werden“ (ebd.). Entscheidend ist hierbei, dass trotz der Schaffung eines bearbeitungsfähigen Binnenbereichs, der Komplexität zu reduzieren erlaubt, ,die aufgebauten Grenzen zwischen Innen und Außen im betrachteten System immer wieder durchbrochen werden“ (ebd.). Die Differenz zwischen

\section{Die Komplexität von Problemen spiegelt sich in den Schwierigkeiten, kontextneutralisierende und kontextoffene Analysestrategien sinnvoll zu konfigurieren.}

hierbei der paradigmatische Fall. Die Analyse von Nachhaltigkeit bedarf methodischer Verfahren, die anderen Rationalitätsmaßstäben folgen. Dieser Wechsel lässt sich mit einer Unterscheidung beschreiben, die zur Charakterisierung zwischen kontextneutralisierenden und kontextoffenen Formen der Risikokommunikation eingeführt wurde (Giegel 1993). Obgleich diese Unterscheidung einer anderen Debatte entstammt, stellt sie gleichwohl ein formtheoretisches Argument dar, das für andere Problemstellungen fruchtbar gemacht werden kann, so auch für Analysestrategien komplexer Probleme innerhalb der problemorientierten Forschung.

Die erste Form der Risikokommunikation zeichne sich, so Giegel, dadurch aus, dass sie einer Operationsweise ähnlich der von ausdifferenzierten Teilsystemen folge: Kontextneutralisierende Operationen ,sind dadurch gekennzeichnet, dass sie eine strikte Grenze ziehen zwischen einem Innenbereich, in dem Komplexität drastisch reduziert, und einem Außenbereich, den man in seiner Überkomplexität nicht versteht und schon gar nicht praktisch beherrscht" (Giegel 1993, S. 107). Jedoch fordert dieser Gewinn an Rationalisierung im Binnenbereich eine besondere Stabilität von sozialen und naturalen Faktoren. Denn ganz offensichtlich können solche Operationen, wie sie etwa in großen Kraftwerken realisiert sind, die für sie erforderliche sozio-materielle Umwelt (also etwa: erforderliche Standards, Infrastrukturen, Humankapital, gesetzliche Grundlagen des Betreibens u. v. m.) nicht selbst herstellen. Kontextneutralisierende Operationen ignorieren auf der Grundlage solcher Voraussetzungen Umweltkomplexität.

Im Gegensatz dazu bleibe bei kontextoffenen Operationen „der Versuch einer strikten Grenzziehung zwischen systemintern geregelter und systemexterner lebensweltlicher Kommunikation [...] in sich widersprüchlich“ (ebd., S. 108). Diese Form von Operationen finden wir gerade in solchen Bereichen, in denen diesen beiden Operationsweisen besteht also nicht in der Schaffung von komplexitätsentlasteten Binnenbereichen, sondern in der Sensibilität bezüglich des Umgangs mit den dadurch zugleich geschaffenen Grenzen.

In der TA finden wir die Anwendung beider Operationsformen als Analysestrategien. TA nutzt kontextneutralisierende Operationen in den Fällen, in denen schon eine klare Systemdefinition für das zu thematisierende Problem vorliegt. Kontextoffene Operationen sind dann hilfreich für TA-Analysen, wenn die Konturen des Problems nicht abschließend definiert und gerade die Exploration des Problems Teil der Fragestellung für TA sind. Eine gegenstandsadäquate Auswahl von Analysestrategien stellt prinzipiell eine Herausforderung für TA dar. Eine Tendenz zu kontextneutralisierenden Analysestrategien ist zu konstatieren. Die Komplexität von Problemen spiegelt sich in den Schwierigkeiten, kontextneutralisierende und kontextoffene Analysestrategien sinnvoll zu konfigurieren. Begrifflich kann Indikatorenarbeit als die Auswahl- und Konfigurationstätigkeit von Indikatoren im Spannungsfeld dieser beiden Analysestrategien verstanden werden.

\section{Analysestrategien und Indikatorenarbeit in der TA}

Indikatoren repräsentieren Effekt-bezogene Wirklichkeitsausschnitte aus zu analysierenden Problemfeldern. Im Gegensatz dazu lassen sich Kriterien in der Weise definieren, dass sie vor dem Hintergrund bestimmter Werthaltungen und Interessen Indikatoren valuieren und für die Charakterisierung eines Problems als relevant positionieren (Boavida und Böschen 2015, S. 38). Die Auswahl und der Zuschnitt von Indikatoren werden umso aufwändiger und schwieriger je komplexer sich das Pro- 
blem darstellt. Nehmen wir ein Beispiel aus dem Bereich der Mobilität. Die Nutzung von Pkws hat nach dem zweiten Weltkrieg nicht nur zugenommen, sondern zugleich zeigen sich relevante Engführungen in der Analyse von Automobilität anhand der (Nicht-)Relevanz von ausgesuchten Indikatoren. Autos galten lange Zeit als Ausdruck für einen modernen Lebensstil. Indikatoren zur Analyse ihrer Auswirkung auf Luftqualität und Treibhauseffekt wurden in den 1950er- und 1960er-Jahren in Studien zur Technologieentwicklung nicht herangezogen. Von 1950 bis 1980 nahm die Zahl der Pkws in Wien von 19.216 auf 470.826 zu. Ab 1980, nach der Energiekrise, gab es einen Impuls für effizientere und umweltschonendere Pkws und eine kontextoffene Betrachtung der Mobilität. Dennoch hat das Prestige einer Marke im Pkw-Markt nach wie vor einen hohen Stellenwert in Kaufentscheidungen von Pkws. Indikatoren, wie der langfristige gesamtgesellschaftliche gesundheitliche Schaden, spielen bei Kaufentscheidungen nur eine begrenzte Rolle. Das lässt sich als kontextneutralisierende Operation verstehen.

Für die TA stellt sich dann die Frage, mit welchen Indikatoren sich eine Erweiterung des Blickfeldes in der Praxis erzielen lässt, also solche Formen der Kontextneutralisierung aufgebrochen werden können. Neben der Konturierung einer Problemlage ermöglichen Indikatoren darüber hinaus einen Vergleich zwischen Ist- und Sollwerten, weil sie Differenzsetzungen abbildbar machen. Gerade deshalb stellt die Indikatorenarbeit einen anspruchsvollen Prozess dar, der im Rahmen von TA-Projekten oftmals nicht die gebührende Aufmerksamkeit erhält (Boavida und Böschen 2015). Dabei lassen sich zumindest drei relevante Problemkreise ausmachen.

Der erste Problemkreis hängt mit verschiedenen Definitionen und Nutzungsformen von Indikatoren zusammen. Dabei werden Indikatoren von einer Problemstellung auf eine andere übertragen, obgleich Analogiesicherheit nicht notwendig gegeben ist. Die unterstellte Analogiesicherheit offenbart eine kontextneutralisierende Analysestrategie. Denn dabei werden gleichbleibende Systemvariablen zu dessen Charakterisierung unterstellt, obgleich diese sich ja gerade bei einer problemorientierten Forschung in Abhängigkeit von dem Lösungseingriff sehr wohl unterscheiden können. Die Frage der Repräsentativität von Indikatoren für ein ausgesuchtes Problem muss also immer wieder aufgeworfen werden. Mit Blick auf das Beispiel: Der Indikator „,mobilitätsbedingte Schadstoffbelastung der Luft“ ist z. B. je nach Vorbelastung der Umgebung oder Besiedelungsdichte zu spezifizieren. Eine kontextoffene Strategie ist hierbei behilflich.

Der zweite Problemkreis ergibt sich daraus, dass mit Indikatoren Trugbilder über die zu definierenden und zu lösenden Probleme entstehen können. Bei komplexen Problemen kommt es notwendigerweise zu einem Beschreibungsdefizit durch Indikatoren. Dies ist grundsätzlich auch gar nicht aufzulösen. Daneben stellen sich, viel basaler und zugleich schlichter, oftmals Fragen der Datenverfügbarkeit, oder -aggregation, welche die Auswahl von Indikatoren letztlich steuern. Zudem erzeugt die Festlegung von Systemgrenzen Wirklichkeitsbeschreibungen, welche, bildlich gesprochen, die Differenz von Karte und Gebiet weiter ver- tiefen. Kontextneutralisierende Strategien lassen diese Differenz mehr oder weniger unbeachtet. Bei kontextoffenen Analysestrategien wird dieser Umstand dadurch kompensiert, dass systematisch die Reduktion von Beschreibungskomplexität nachvollziehbar und damit durch die Analyse entstehende Beschreibungsdefizite transparent gemacht werden.

Der dritte Problemkreis schließlich verbindet sich mit der politischen Deutung von Indikatoren. Die Nutzung von Indikatoren suggeriert das Vorliegen von Steuerungsfähigkeit wie -rationalität. Mit Indikatoren werden nicht nur steuerungsfähige Gegenstände geschaffen, sondern durch diese Wissensform eine inhärente Rationalität des Steuerungszwecks mit konstituiert. Zugleich prägen Indikatoren Wirklichkeitsbilder, welche dann als Zielbilder für die gesellschaftliche Entwicklung zirkulieren und einflussreich werden können (wie etwa Wirtschaftsentwicklung durch BIP zu betrachten).

Indikatorenarbeit berücksichtigt gezielt beide Analysestrategien - oder sollte dies zumindest tun. Kontextneutralisierende Analysestrategien beruhen darauf, dass Systeme möglichst mit einem Standardset von Indikatoren behandelt werden. Mittels dieses methodischen Vorgehens wird ein objektiviertes Bild von der Problemsituation und den Lösungsstrategien sowie Modelleindeutigkeit angestrebt. Bei kontextoffenen Analysestrategien hingegen wird die Indikatorenarbeit als Konstruktionsarbeit von Problemen und ihrer Lösung verstanden, bei der die Beschreibungsvielfalt gewürdigt und auf dieser Basis eine pragmatisch wirkungsvolle Problemdeutung vorgenommen wird. In Abhängigkeit von der gesellschaftlichen Problemlösungssituation in einem zur Untersuchung stehenden Feld kann TA die beiden Strategien gezielt einsetzen. Wenn die öffentlich-politische Problemdebatte an problematischen Fokussierungen leidet, dann sollte TA auf kontextoffene Strategien setzen, um den Problemlösungshorizont zu weiten - verliert sich die Debatte hingegen in Unübersichtlichkeit, dann können kontextneutralisierende Angebote zur Komplexitätsreduktion hilfreich sein. Gleichwohl ist immer auf den Gegenstandsbezug zu achten. Dies umso mehr, als Akteure ihre partikulären Perspektiven mit je eigenen Indikatoren gerade dann exponieren, wenn eine übergreifende Strukturierung von Problemen noch nicht vorliegt. Indikatorenarbeit und damit einhergehende Besonderheiten werden nachfolgend an einem TA-Projekt im Feld der Nachhaltigkeit verdeutlicht.

\section{Indikatorenarbeit in einem konkreten TA-Projekt}

Nachhaltigkeitsanalysen, wie jene von Kopfmüller et al. (2001), basieren häufig auf hoch elaborierten Bewertungssystemen, in denen die Indikatorenarbeit relativ stark formalisiert ist. $\mathrm{Zu}$ gleich zeigen sich hier auch die Grenzen der Formalisierung, so dass deutlich gemacht werden kann, wie normative Wertsetzungen in die Analyse einfließen und das Ergebnis prägen. Das konkrete Projektbeispiel stammt aus dem Feld des „Integrativen Konzepts nachhaltiger Entwicklung" (IKoNE) (Kopfmüller et al. 
2001). Es bezieht sich auf einen kleinräumigen Fall, das Konzept kann gleichwohl aber auf beliebig komplizierte Prozesse angewendet werden (Schippl et al. 2017).

\section{IKoNE: Grundlagen}

Die normativen Grundlagen der Nachhaltigkeitsdefinition für IKoNE folgen den drei konstitutiven Elementen der Nachhaltigkeit (Hauff 1987):

- Inter- und intragenerative Gerechtigkeit;

- Betrachtung der lokalen, regionalen und globalen Bezugsrahmen;

- Naturschutz in einem anthropozentrisch begründeten, aber sehr weiten Bedeutungsrahmen.

Diese konstitutiven Elemente werden in IKoNE in drei generelle Ziele übersetzt: (1) die Sicherung der menschlichen Existenz; (2) die Erhaltung des gesellschaftlichen Produktivpotenzials sowie (3) die Bewahrung der Entwicklungs- und Hand-

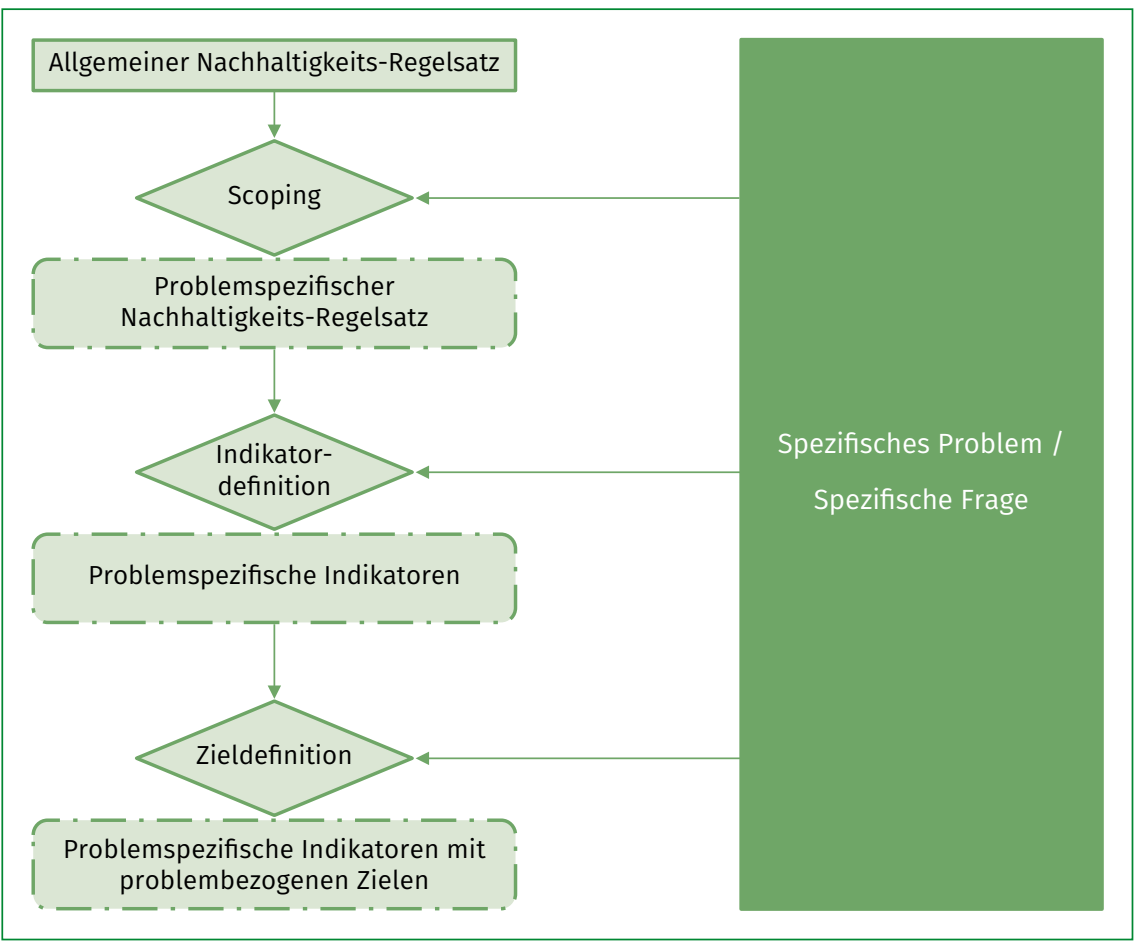
lungsmöglichkeiten der Gesellschaft. Diese stellen die erste Ebene der normativen Hierarchie der Nachhaltigkeitsbewertung nach IKoNE dar. Die drei generellen Nachhaltigkeitsziele werden durch 15 substanzielle Regeln oder Handlungsleitlinien konkretisiert (Tabelle 1). Diese explizit normative Herleitung der Nachhaltigkeitsziele basiert zum einen auf dem Brundtlandbericht und den Rio-Dokumenten, ist zum anderen Ergebnis unterschiedlicher wissenschaftlicher Diskurse. Die Begründung der Entscheidung für die eine oder die andere Definition, z. B. von Gerechtigkeit als soziale Gerechtigkeit (ebd., S. $130 \mathrm{ff}$.), kann so transparent und zum Gegenstand von Diskursen gemacht werden. Dies ist eine normative Setzung im Modell selbst.

Diese Regeln werden generell bei Nachhaltigkeitsbewertungen angewendet. Dabei wird in einem ersten Schritt, dem Scoping, geprüft, ob für die konkrete Fragestellung, wie z. B. die Anwendung einer Technologie in einem bestimmten gesellschaftlichen Kontext, alle Regeln betroffen sind (Abb. 1). Diese Regelauswahl ist direkt abhängig von der Fragestellung, d. h. dem Kontext. Dieser Schritt der Indikatorenarbeit, welcher genau genommen die Kriterien auswählt, zu denen späterhin Indikatoren definiert werden, hat einen erheblichen kontextneutralisierenden Effekt - bei gleichzeitig weitreichender normativer Wertung.

\section{Ländliche Räume in Baden-Württemberg}

Im sogenannten Grünlandprojekt, das von 2003 bis 2006 vom Institut für Technikfolgenabschätzung und Systemanalyse (ITAS) im Auftrag des Ministeriums für Ländlichen Raum und Verbraucherschutz Baden-Württemberg durchgeführt wurde (Rösch

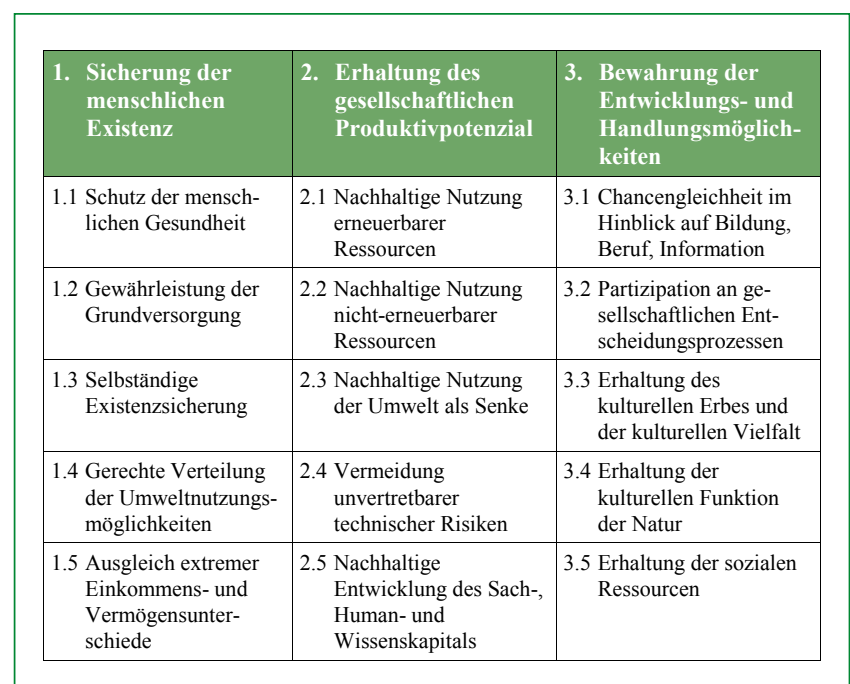

Tab. 1: Die drei generellen Ziele und die ihnen zugeordneten substanziellen Nachhaltigkeitsregeln (die „Was-Regeln“ der Nachhaltigkeit).

Quelle: Kopfmüller et al. 2001, S. 172

2007; Rösch et al. 2007), lautete die Fragestellung: „Ist energetische Nutzung der Grasaufwuchs auf Überschussgrünland nachhaltig?" Um diese Frage zu beantworten, wurden in einem Workshop mit Expert*innen und Stakeholdern die folgenden sieben Regeln als relevant eingeschätzt: (1.1) Der Schutz der menschlichen Gesundheit; (1.3) Selbständige Existenzsicherung; (1.4) 


\begin{tabular}{|c|c|}
\hline $\begin{array}{l}\text { Mindestbedingungen } \\
\text { nachhaltiger Entwicklung }\end{array}$ & Nachhaltigkeitsindikatoren \\
\hline $\begin{array}{l}\text { Gerechte Verteilung der } \\
\text { Umweltnutzungsmöglichkeiten }\end{array}$ & $\begin{array}{l}\text { Substitution nicht erneuerbarer Energieträger } \\
\text { Klimarelevante Emissionen }\end{array}$ \\
\hline $\begin{array}{l}\text { Nachhaltige Nutzung nicht } \\
\text { erneuerbarer Ressourcen }\end{array}$ & $\begin{array}{l}\text { Substitution nicht erneuerbarer Energieträger (s.o.) } \\
\text { Flächenspezifischer Primärenergieertrag } \\
\text { Flächenspezifische Vermeidung klimarelevanter Emissionen }\end{array}$ \\
\hline $\begin{array}{l}\text { Nachhaltige Nutzung der } \\
\text { Umwelt als Senke }\end{array}$ & $\begin{array}{l}\text { Klimarelevante Emissionen (s.o.) } \\
\mathrm{CO}_{2} \text {-Vermeidungskosten } \\
\text { Eutrophierend wirkende Emissionen } \\
\text { Versauernd wirkende Emissionen }\end{array}$ \\
\hline $\begin{array}{l}\text { Schutz der menschlichen } \\
\text { Gesundheit }\end{array}$ & $\begin{array}{l}\text { Feinstaubemissionen } \\
\mathrm{NO}_{\mathrm{x}} \text {-Emissionen } \\
\mathrm{CO} \text {-Emissionen } \\
\text { Sommersmog } \\
\text { Pilzsporen }\end{array}$ \\
\hline $\begin{array}{l}\text { Nachhaltige Nutzung } \\
\text { erneuerbarer Ressourcen }\end{array}$ & $\begin{array}{l}\text { Biodiversität } \\
\text { Boden } \\
\text { Grund- und Oberflächengewässer }\end{array}$ \\
\hline $\begin{array}{l}\text { Erhalt der kulturellen } \\
\text { Funktion der Natur }\end{array}$ & Landschaftsbild \\
\hline $\begin{array}{l}\text { Selbstständige } \\
\text { Existenzsicherung }\end{array}$ & $\begin{array}{l}\text { Beschäftigung } \\
\text { Entlohnung }\end{array}$ \\
\hline
\end{tabular}

Tab. 2: Ausgewählte Indikatoren zur Operationalisierung der Mindestanforderungen nachhaltiger Entwicklung.

Quelle: Rösch et al. 2007, S. 103

beim Erstellen eines Gesamtindikatorensatzes treffen zwei konfligierende pragmatische Ansprüche aufeinander: Je mehr Aspekte einer Regelanwendung durch Indikatoren abgedeckt werden, desto umfassender und damit klarer repräsentiert der Indikatorensatz die Regelanwendung. Aber jeder Indikator mehr erhöht Aufwand wie Kosten und macht die Darstellung potenziell unübersichtlicher. Bei diesem Schritt zeigt sich die schwierige Balance zwischen kontextneutralisierenden und kontextoffenen Analysestrategien ganz prägnant. Neutralisierung erlaubt eine knappe, prägnante und oftmals pragmatisch einfachere Analyse. Öffnung bedeutet Aufwand, manchmal auch Unübersichtlichkeit; dafür geht sie jedoch mit einer detailreicheren Darstellung der Problemlage einher. Da das Ergebnis von derartigen Prozessen oft an externe Akteure (Politik, Unternehmer) gerichtet ist, die nur über begrenzte Aufmerksamkeitsressourcen verfügen, kann sich leicht eine

Gerechte Verteilung der Umweltnutzungsmöglichkeiten; (2.1) Nachhaltige Nutzung erneuerbarer Ressourcen; (2.2) Nachhaltige Nutzung nicht erneuerbarer Ressourcen; (2.3) Nachhaltige Nutzung der Umwelt als Senke sowie (3.4) Erhalt der kulturellen Funktion der Natur. Diese Regeln wurden in einem nächsten Schritt durch Indikatoren operationalisiert (Abb. 1). Der prinzipiell kontextneutralisierenden Qualität dieses Schrittes mit der Gefahr implizit bleibender normativer Wertungen kann durch Perspektivendifferenzierung in Beteiligungsverfahren entgegengewirkt werden.

Die Gesundheitsregel (1.1) wurde vor allem mit den Indikatoren $\mathrm{NO}_{\mathrm{x}}$ - und $\mathrm{CO}$-Emissionen bewertet, da diese Substanzen bei der Umwandlung von Grünlandaufwuchs in Energie frei-
Präferenz für kontextneutralisierende Strategien einschleichen. Auch hier war ein mehrschichtiger Diskurs mit ExpertInnen die Methode der Wahl, wobei 18 Indikatoren herausgearbeitet wurden (Tabelle 2). Bei aller methodischer Finesse spiegelt ein solcher Indikatorensatz freilich normative Setzungen wider.

Für einen Teil der Indikatoren wurden anschließend Stoffstromanalysen erstellt (z. B. klimarelevante Emissionen und $\mathrm{NO}_{\mathrm{x}}$-Emissionen durch Biomasseverbrennung). Für andere wurden quantitative Berechnungen durchgeführt (Beschäftigung, Entlohnung), und einige wurden verbal beschrieben (z. B. Biodiversität). Für die Betrachtungen erfolgten Festlegungen von Kontext (Bilanzgrenzen) und von Rahmenbedingungen, die bei der Erarbeitung der Indikatorwerte herangezogen wurden. Die

\section{Für die Zusammenstellung eines Indikatorensatzes gilt: „So viel Indikatoren wie nötig, aber so wenig wie möglich“.}

gesetzt werden können. Gesundheitsschäden durch radioaktive Strahlung wurden hingegen nicht betrachtet, da diese im genannten Fall keine Rolle spielen. Neben sachlichen Kriterien spielen ebenso pragmatische Kriterien wie die Datenverfügbarkeit oder -qualität eine Rolle. Wenn es zu einem Indikator keine Angaben - Zahlenwerte oder deskriptive Beschreibungen - gibt, so kann dieser nicht für die Beantwortung der vorliegenden Fragestellung herangezogen werden.

Für die Zusammenstellung eines Indikatorensatzes gilt: ,So viel Indikatoren wie nötig, aber so wenig wie möglich“. Denn
Festlegung der Bilanzgrenzen ist ein Schritt, bei dem ebenfalls normative Setzungen vorgenommen werden (z. B. ob der Energieaufwand bei der Kunstdüngerproduktion in die Bewertung einbezogen wird, oder, ob das Ausbringen der Reste aus der Biogasanlage auf das Feld Berücksichtigung findet, oder nicht). Schließlich enthalten die Zielwerte, die erreicht werden sollen, spezifische normative Festlegungen, die oftmals durch die geltenden Gesetze vorgegeben werden - aber in Studien, die nicht auf solche rechtlichen Festlegungen zurückgreifen können, spiegeln Zielwerte Erwartungen wider, wobei darauf geachtet wer- 
den muss, dass dies nicht selektiv Erwartungen partikularer Akteursgruppen sind.

Tabelle 3 zeigt, dass mit Hilfe von Indikatoren methodisch verschieden generierte Fakten in einem vereinheitlichten Bewertungsschema und Modell dargestellt wurden. Diese Tabelle macht deutlich, dass ein solches Ergebnis, das eine Fülle von kontextoffenen Elementen enthält (Vielzahl von Kriterien und Indikatoren einerseits sowie Vielfalt von Handlungsoptionen in Form von Varianten der Landwirtschaft wie Technologien andererseits), zwar eine vielschichtigere Beschreibung erlaubt, zugleich aber Entscheidungskomplexität nur begrenzt reduziert. Auf der anderen Seite macht sie aber die konkreten Entscheidungsmöglichkeiten und ihre normativen Bezüge transparent.

In dem beschriebenen Fall realisierte sich die kontextbezogene Normativität demnach insbesondere an vier Stellen im Bewertungsprozess: 1) Bei der Auswahl der als relevant eingeordneten Regeln; 2) der Festlegung der Bilanzgrenzen; 3) der problemorientierten Auswahl der Indikatoren; und schließlich 4) der Festlegung der Bewertungsmaßstäbe (Zielwerte, Referenzwerte etc.).

\section{Diskussion und Ausblick}

Das geschilderte Projekt zeigt auf, wie in allen Schritten Indikatorenarbeit als Konfiguration von kontextneutralisierenden und kontextoffenen Analysestrategien geleistet werden muss. Auf der einen Seite werden Indikatoren in Nachhaltigkeitsanalysen durch regelbasiertes Vorgehen schrittweise begrenzt und definiert. Auf diese Weise wird kontextneutralisierend der Raum der Beschreibung so weit reduziert, dass ein Problembinnenraum entsteht, der dann Gegenstand der Analyse ist. Auf der anderen Seite öffnet sich in jeder Phase des Drei-Schritts vom Scoping über die Indikatordefinition zur Zieldefinition zugleich ein Gelegenheitsfenster für eine kontextoffene Arbeitsstrategie. Indem nämlich die jeweiligen Selektionsprozesse reflexiv vollzogen werden, kann der Außenraum (Kontext) im Problembinnenraum immer wieder zum Sprechen gebracht werden.

Ein zentraler Punkt, der für den Ausgleich der inhärenten Spannung zwischen einer kontextneutralisierenden und kontext-

\begin{tabular}{|c|c|c|c|c|c|c|c|c|c|}
\hline & \multicolumn{5}{|c|}{ Extensive Grünlandflächen } & \multicolumn{4}{|c|}{ Intensive Grünlandflächen } \\
\hline & \multicolumn{4}{|c|}{ Nutzung } & \multirow{2}{*}{$\begin{array}{l}\text { Um- } \\
\text { wand- } \\
\text { lung } \\
\text { KUP } \\
\text { ext. }\end{array}$} & \multirow{2}{*}{$\begin{array}{l}\begin{array}{l}\text { Nut- } \\
\text { zung }\end{array} \\
\begin{array}{l}\text { Gras- } \\
\text { silage }\end{array}\end{array}$} & \multicolumn{3}{|c|}{ Umwandlung } \\
\hline & $\begin{array}{l}\mathrm{Heu} \\
\mathrm{HD}\end{array}$ & $\begin{array}{l}\mathrm{Heu} \\
\mathrm{RB}\end{array}$ & $\begin{array}{l}\text { Heu } \\
\text { Pellets }\end{array}$ & $\begin{array}{l}\text { Heu } \\
\mathrm{TF}^{1)}\end{array}$ & & & $\begin{array}{l}\text { Mais- } \\
\text { silage }\end{array}$ & $\begin{array}{l}\text { KUP } \\
\text { int. }\end{array}$ & $\mathrm{KUP}^{2)}$ \\
\hline \multicolumn{10}{|c|}{ Nachhaltige Nutzung nicht erneuerbarer Ressourcen } \\
\hline Primärenergieertrag & $\begin{array}{c}++ \\
(7)^{3)} \\
\end{array}$ & $\begin{array}{l}++ \\
(6)\end{array}$ & $\begin{array}{l}++ \\
(5) \\
\end{array}$ & $\begin{array}{l}++ \\
(8)\end{array}$ & $\begin{array}{l}++ \\
(3)\end{array}$ & $\begin{array}{l}++ \\
(4)\end{array}$ & $\begin{array}{l}++ \\
(2)\end{array}$ & $\begin{array}{l}++ \\
(1)\end{array}$ & $\begin{array}{l}++ \\
(1)\end{array}$ \\
\hline \multicolumn{10}{|c|}{ Nachhaltige Nutzung der Umwelt als Senke } \\
\hline $\begin{array}{l}\text { Klimarelevante } \\
\text { Emissionen }\end{array}$ & $\begin{array}{l}++ \\
(6)\end{array}$ & $\begin{array}{l}++ \\
(5)\end{array}$ & $\begin{array}{l}++ \\
(4)\end{array}$ & $\begin{array}{c}+ \\
+ \\
(8)\end{array}$ & $\begin{array}{l}++ \\
(2)\end{array}$ & $\begin{array}{l}++ \\
(7)\end{array}$ & $\begin{array}{l}++ \\
(3)\end{array}$ & $\begin{array}{l}++ \\
(1)\end{array}$ & $\begin{array}{l}++ \\
(1)\end{array}$ \\
\hline $\begin{array}{l}\mathrm{CO}_{2} \text {-Vermeidungs- } \\
\text { kosten }\end{array}$ & $\begin{array}{l}- \\
(5)\end{array}$ & $\begin{array}{l}- \\
\text { (3) }\end{array}$ & (3) & $\begin{array}{l}-- \\
(6)\end{array}$ & $\begin{array}{c}+ \\
+ \\
(2)\end{array}$ & $\begin{array}{l}-- \\
(4)\end{array}$ & $\begin{array}{l}-- \\
(4)\end{array}$ & $\begin{array}{l}++ \\
(1)\end{array}$ & $\begin{array}{l}++ \\
(1)\end{array}$ \\
\hline $\begin{array}{l}\text { Eutrophierende } \\
\text { Emissionen }\end{array}$ & $\begin{array}{c}- \\
(5)\end{array}$ & $\begin{array}{c}0 \\
(3)\end{array}$ & $\begin{array}{l}- \\
(6)\end{array}$ & (9) & $\begin{array}{c}0 \\
(2)\end{array}$ & $\begin{array}{l}-- \\
(8)\end{array}$ & $\begin{array}{l}-- \\
(7)\end{array}$ & $\begin{array}{c}0 \\
(3)\end{array}$ & $\begin{array}{c}0 \\
(1) \\
\end{array}$ \\
\hline $\begin{array}{l}\text { Versauernde } \\
\text { Emissionen }\end{array}$ & $\begin{array}{c}- \\
(5)\end{array}$ & $\begin{array}{c}0 \\
(4)\end{array}$ & $\begin{array}{l}- \\
(6) \\
\end{array}$ & $\begin{array}{l}-- \\
(9)\end{array}$ & $\begin{array}{c}+ \\
(3) \\
\end{array}$ & $\begin{array}{l}-- \\
(8)\end{array}$ & $\begin{array}{l}-- \\
(7)\end{array}$ & $\begin{array}{c}+ \\
(2) \\
\end{array}$ & $\begin{array}{c}+ \\
(1) \\
\end{array}$ \\
\hline \multicolumn{10}{|c|}{ Schutz der menschlichen Gesundheit } \\
\hline Feinstaubemissionen & $\begin{array}{c}0 \\
(4)\end{array}$ & $\begin{array}{c}- \\
(7) \\
\end{array}$ & $\begin{array}{l}- \\
(5) \\
\end{array}$ & $\begin{array}{c}+ \\
(1) \\
\end{array}$ & $\begin{array}{c}- \\
(8)\end{array}$ & $\begin{array}{c}0 \\
(2) \\
\end{array}$ & $\begin{array}{c}0 \\
(3) \\
\end{array}$ & $\begin{array}{l}-- \\
(9)\end{array}$ & $\begin{array}{c}- \\
(6) \\
\end{array}$ \\
\hline $\mathrm{NO}_{\mathrm{x}}$-Emissionen & $\begin{array}{l}-- \\
(7) \\
\end{array}$ & $\begin{array}{l}-- \\
(6)\end{array}$ & $\begin{array}{l}-- \\
(8)\end{array}$ & $\begin{array}{c}+ \\
(1) \\
\end{array}$ & $\begin{array}{c}- \\
(4) \\
\end{array}$ & $\begin{array}{l}- \\
(3) \\
\end{array}$ & $\begin{array}{l}- \\
(5) \\
\end{array}$ & $\begin{array}{l}-- \\
(6)\end{array}$ & $\begin{array}{l}- \\
(2)\end{array}$ \\
\hline CO-Emissionen & $\begin{array}{l}-- \\
(9)\end{array}$ & $\begin{array}{c}+ \\
(2) \\
\end{array}$ & $\begin{array}{c}0 \\
(3) \\
\end{array}$ & $\begin{array}{c}0 \\
(4)\end{array}$ & $\begin{array}{l}-\overline{6} \\
(6)\end{array}$ & $\begin{array}{l}-\overline{1} \\
(5) \\
\end{array}$ & $\begin{array}{l}-- \\
(7)\end{array}$ & $\begin{array}{l}-- \\
(8\end{array}$ & $\begin{array}{c}+ \\
(1) \\
\end{array}$ \\
\hline Sommersmog & $\begin{array}{l}-- \\
(8)\end{array}$ & $\begin{array}{c}- \\
(7)\end{array}$ & $\begin{array}{l}-- \\
(9)\end{array}$ & $\begin{array}{c}+ \\
(1)\end{array}$ & $\begin{array}{l}- \\
(4)\end{array}$ & $\begin{array}{l}- \\
\text { (3) }\end{array}$ & $\begin{array}{l}- \\
(5)\end{array}$ & $\begin{array}{l}- \\
(6)\end{array}$ & $\begin{array}{c}0 \\
(2)\end{array}$ \\
\hline Pilzsporen & 0 & 0 & 0 & - & - & 0 & 0 & - & - \\
\hline \multicolumn{10}{|c|}{ Nachhaltige Nutzung erneuerbarer Ressourcen } \\
\hline Biodiversität & $\begin{array}{c}+ \\
(1) \\
\end{array}$ & $\begin{array}{c}+ \\
(1) \\
\end{array}$ & $\begin{array}{c}+ \\
(1) \\
\end{array}$ & $\begin{array}{c}+ \\
(1) \\
\end{array}$ & $\begin{array}{l}- \\
(4)\end{array}$ & $\begin{array}{l}0 /- \\
(2)\end{array}$ & $\begin{array}{l}-- \\
(5)\end{array}$ & $\begin{array}{c}0 \\
(3)\end{array}$ & $\begin{array}{c}0 \\
(3) \\
\end{array}$ \\
\hline Boden & $\begin{array}{c}0 \\
(1) \\
\end{array}$ & $\begin{array}{c}0 \\
(1)\end{array}$ & $\begin{array}{c}0 \\
(1) \\
\end{array}$ & $\begin{array}{c}0 \\
(1)\end{array}$ & $\begin{array}{l}- \\
(2) \\
\end{array}$ & $\begin{array}{c}0 \\
(1) \\
\end{array}$ & $\begin{array}{l}-- \\
(3)\end{array}$ & $\overline{(2)}$ & $\begin{array}{l}- \\
(2) \\
\end{array}$ \\
\hline $\begin{array}{l}\text { Grund- und Oberflä- } \\
\text { chengewässer }\end{array}$ & $\begin{array}{c}0 \\
(1)\end{array}$ & $\begin{array}{c}0 \\
(1)\end{array}$ & $\begin{array}{c}0 \\
(1)\end{array}$ & $\begin{array}{c}0 \\
(1)\end{array}$ & $\begin{array}{l}- \\
(2)\end{array}$ & $\begin{array}{c}0 \\
(1)\end{array}$ & $\begin{array}{l}-- \\
(3)\end{array}$ & $\begin{array}{l}- \\
(2)\end{array}$ & $\begin{array}{l}- \\
(2)\end{array}$ \\
\hline \multicolumn{10}{|c|}{ Kulturelle Funktion der Natur } \\
\hline Landschaft & $\begin{array}{c}+ \\
(1)\end{array}$ & $\begin{array}{c}++ \\
(1)\end{array}$ & $\begin{array}{c}+ \\
(1)\end{array}$ & $\begin{array}{c}+ \\
(1)\end{array}$ & $\begin{array}{l}-/+ \\
(2)\end{array}$ & $\begin{array}{c}+ \\
\text { (1) }\end{array}$ & $\begin{array}{l}-\overline{1} \\
(3)\end{array}$ & $\begin{array}{l}-/+ \\
(2)\end{array}$ & $\begin{array}{l}-/+ \\
(2)\end{array}$ \\
\hline \multicolumn{10}{|c|}{ Selbstständige Existenzsicherung } \\
\hline Beschäftigung & $\begin{array}{c}+ \\
+(1)\end{array}$ & $\begin{array}{c}++ \\
(4) \\
\end{array}$ & $\begin{array}{c}+ \\
(8) \\
\end{array}$ & $\begin{array}{c}+ \\
(7)^{4)}\end{array}$ & $\begin{array}{l}+ \\
(6) \\
\end{array}$ & $\begin{array}{c}+ \\
(5) \\
\end{array}$ & $\begin{array}{l}+ \\
\text { (2) } \\
\end{array}$ & $\begin{array}{c}+ \\
+ \\
(3)\end{array}$ & $\begin{array}{c}+ \\
\text { (3) } \\
\end{array}$ \\
\hline Entlohnung & $\begin{array}{l}- \\
(7)\end{array}$ & $\begin{array}{c}+ \\
(5) \\
\end{array}$ & $\begin{array}{l}- \\
(8)\end{array}$ & $\begin{array}{l}+ \\
(6)^{4)} \\
\end{array}$ & $\begin{array}{l}++ \\
(2)\end{array}$ & $\begin{array}{c}+ \\
(4) \\
\end{array}$ & $\begin{array}{c}+ \\
(3) \\
\end{array}$ & $\begin{array}{l}++ \\
(1)\end{array}$ & $\begin{array}{l}++ \\
(1)\end{array}$ \\
\hline
\end{tabular}

${ }^{1)}$ Trockenfermentation von Heu zusammen mit Maissilage.

${ }^{2)}$ Verbrennung von Kurzumtriebspappeln (KUP) in Kesseln mit emissionsarmer Verbrennung.

3) +/- geben an, ob das Verfahren im Vergleich zur Referenz (Mulchen, fossile Energieträger) positiv/negativ

ist, die Zahlen 1 (gut) bis 9 (schlecht) die Rangfolge der Verfahren verglichen mit den anderen Verfahren.

${ }^{4)}$ Diese Angaben gelten für die Co-Fermentation von Extensivheu mit Maissilage.

Tab. 3: Bewertung der unterschiedlichen Verfahren. Obwohl einige Indikatoren durch Modelle oder eigene Tools berechnet oder verbal beschrieben wurden, wurden sie in diesem Fall durch eine fünfstufige Skala $(++,+, 0,-,--)$ normiert. Quelle: Rösch et al. 2007, S. 144 offenen Analysestrategie ins Auge sticht, ist die soziale Absicherung der Prozessschritte - mit zwei Aspekten. Zum einen kann die sachliche Komplexität umso eher hinsichtlich ihrer normativen Beeinflussung erfasst werden, wenn es gelingt, durch eine korrespondierende soziale Prozesskomplexität die Chancen auf Transparenz zu steigern. Entscheidend ist also eine durch Indikatoren gestützte Bewertung so durchzuführen, dass die Kriterien für die Indikatorenauswahl transparent und nachvollzieh- 
bar sind. Zum anderen kann diese Analyse umso eher gelingen, wenn durch den Einbezug von unterschiedlichen Akteuren der Kontext genauer zum Sprechen gebracht wird und zu Beginn jedes Schrittes Beteiligungsverfahren eingesetzt werden, um die Umwelt im sukzessive enger definierten Problembinnenraum angemessen zu repräsentieren und dafür die entsprechenden Messgrößen zu sichern. Mit dieser Doppelstrategie (sachlich und sozial) kann die Normativität von TA-Analysen in ihrer Kontextbezogenheit transparent gemacht werden.

Dies ist umso bedeutsamer als die Zunahme von Komplexität im Betrachtungsgegenstand der TA (etwa: Einzeltechnologie, Technologiefamilie, Technologie in ihrem Anwendungsfeld, Region mit den angewandten Technologien) mit einer $\mathrm{Zu}$ nahme normativer Setzungen einhergeht, die in der Regel im Rahmen der Bewertung durchgeführt werden. Zugleich verbinden sich mit diesen Setzungen unterschiedliche Entwicklungsperspektiven, so dass hier ein Feld unterschiedlicher Ausgangsbezüge und Entwicklungsperspektiven dargestellt werden muss. Denn die Definition des Problembinnenraums stellt bei unstrukturierten Problemen (wie etwa der Energiewende oder dem Klimawandel), bei denen Wissen und Werte umstritten sind, Teil des öffentlich-politischen Prozesses dar.

Die Anwendung von Modellen (als kontextneutralisierende Strategie) funktioniert nur bei strukturierten Problemen (Wissen und Werte sind nicht umstritten), da hier schon ein institutioneller Rahmen zur Problembearbeitung existiert. Ansonsten verknüpfen sich mit kontextneutralisierenden Strategien spezifische Wertsetzungen, die aufgrund der scheinbaren Neutralität von Modellen nicht immer sichtbar sind. Würde man also bei unstrukturierten Problemen voreilig einen Problembinnenraum festlegen, so würde dies dem Ergebnis des öffentlich-politischen Diskurses vorgreifen. Indikatorenarbeit ginge dabei in Indikatorenpolitik über (Böschen 2019).

Offenkundig sind kontextneutralisierende wie kontextoffene Analysestrategien relevant für TA. Entscheidend ist für TA-Praktiker die Einsicht in die Bedingungen der Anwendbarkeit der einen oder anderen Form. Indikatorenarbeit bedeutet eine reflektierte Nutzung beider Analysestrategien, um sachadäquat und normtransparent zu verfahren.

\section{Literatur}

Bechmann, Gotthard (1993): Sozialwissenschaftliche Forschung und Technikfolgenabschätzung. In: Klaus Lompe (Hg.): Techniktheorie - Technikforschung - Technikgestaltung. Opladen: Westdeutscher Verlag, S. 28-58. Boavida, Nuno; Böschen, Stefan (2015): Indicators in technology assessment. Passive choices or reflected options. In: Tomas Michalek et al. (Hg.): The next horizon of technology assessment. Prag: Informatorium, S.33-40.

Böschen, Stefan (2019): TA at the crossroads. Politics of TA from the viewpoint of societal problem solving. In: Technological Forecasting and Social Change 139, S. 42-47.

Bröchler, Stephan; Simonis, Georg; Sundermann, Karsten (Hg.) (1999): Handbuch Technikfolgenabschätzung. Berlin: edition sigma.

Giegel, Hans-Joachim (1993): Kontextneutralisierung und Kontextoffenheit als Strukturbedingungen der gesellschaftlichen Risikokommunikation. In:
Wolfgang Bonss, Rainer Hohlfeld und Regine Kollek (Hg.): Wissenschaft als Kontext. Kontexte der Wissenschaft. Hamburg: Junius, S. 103-121.

Grunwald, Armin (Hg.) (1999): Rationale Technikfolgenbeurteilung. Konzepte und methodische Grundlagen. Berlin: Springer.

Hauff, Volker (Hg.) (1987): Unsere gemeinsame Zukunft. Der BrundtlandBericht der Weltkommission für Umwelt und Entwicklung. Greven: Eggenkamp.

Kopfmüller, Jürgen et al. (2001): Nachhaltige Entwicklung integrativ betrachtet. Konstitutive Elemente, Regeln, Indikatoren. Berlin: edition sigma.

Rösch, Christine; Raab, Konrad; Skarka, Johannes; Stelzer, Volker (2007): Energie aus dem Grünland. Eine nachhaltige Entwicklung?. Karlsruhe: Forschungszentrum Karlsruhe. Online verfügbar unter http://www.itas.kit.edu/pub/v/2007/roua07b.pdf, zuletzt geprüft am 29. 01.2019.

Rösch, Christine (2007): Die Nutzung von überschüssigem Grünland als Energieressource. In: TATuP - Zeitschrift für Technikfolgenabschätzung in Theorie und Praxis 16 (3), S. 88-93.

Schippl, Jens; Grunwald, Armin; Renn, Ortwin (2017): Die Energiewende verstehen orientieren - gestalten. Einsichten aus fünf Jahren integrativer Forschung. In: Jens Schippl, Armin Grunwald und Ortwin Renn (Hg.): Die Energiewende verstehen - orientieren - gestalten. Erkenntnisse aus der Helmholtz-Allianz ENERGY-TRANS. Baden-Baden: Nomos, S. 9-34.

Stelzer, Volker; Kopfmüller, Jürgen (2019, im Erscheinen): Sustainability assessment. Integrative concept, methodology and examples. In: Claudia Binder und Stefanie Krauth (Hg.): Sustainability assessments of urban systems. München: Elsevier.

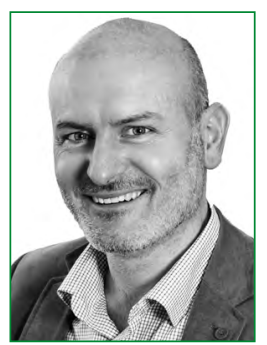

PROF.DR. PHIL. DIPL.-ING. STEFAN BÖSCHEN

leitet den Lehrstuhl „Technik und Gesellschaft“ am Human Technology Center (HumTec) der RWTH Aachen University. Er ist Chemie-Ingenieur und Soziologe mit Schwerpunkten in der Wissenschaftsund Technikforschung sowie Technikfolgenabschätzung.

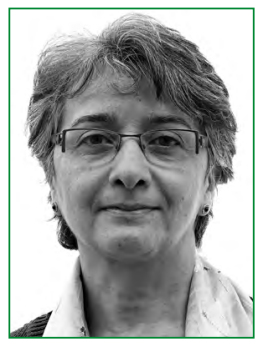

PRIV. DOZ. DI DR.IN MAHSHID SOTOUDEH ist TA-Forscherin mit einem Hintergrund in der Chemie- und Verfahrenstechnik. Ihre Forschungsgebiete sind Technologie und Nachhaltigkeit, partizipative Methoden und Foresight. Sie ist Dozentin mit Venia Legendi „Technikfolgenabschätzung und Nachhaltigkeit" an der Technischen Universität Graz.

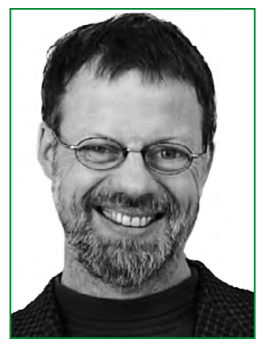

\section{DR. VOLKER STELZER}

ist Senior Scientist und Nachhaltigkeitsforscher am Institut für Technikfolgenabschätzung und Systemanalyse (ITAS) des KIT. Seine Forschungsschwerpunkte sind systematische Nachhaltigkeitsbewertungen in der Stadtentwicklung und der Energieversorgung sowie Zukunftsbetrachtungen mittels Szenarien. 


\title{
The Capability Approach as a normative framework for technology assessment
}

\section{Capabilities in assessing digitalization in the energy transformation}

\author{
Rafaela Hillerbrand, Institute for Technology Assessment and Systems Analysis (ITAS), Karlsruhe Institute of Technology (KIT), \\ Karlstr.11, 76133 Karlsruhe (rafaela.hillerbrand@kit.edu), (1) orcid.org/0000-0002-7890-3715 \\ Christine Milchram, Department of Values, Technology \& Innovation (VTI), Faculty of Technology, Policy \& Management (TPM), \\ TU Delft (c.milchram@tudelft.nl), (1) orcid.org/0000-0002-6325-4329 \\ Jens Schippl, Institute for Technology Assessment and Systems Analysis (ITAS), Karlsruhe Institute of Technology (KIT) \\ (jens.schippl@kit.edu), (1) orcid.org/0000-0003-3169-6365
}

The digital revolution of the energy system promises a new sustainable energy future, but risks security and privacy. How to balance or at least compare these risks against other values like more sustainability is far from obvious and poses severe challenges for the orientation knowledge of technology assessment (TA). This paper explores the Capability Approach (CA) as a normative orientation for TA that allows addressing these challenges. We use two scenarios for the current digitalization in the energy sector as case studies.

\section{Der Capability Approach als normativer Ansatz für die Technikfolgenabschätzung \\ Capabilities und die Digitalisierung in der Energiewende}

Die digitale Revolution des Energiesystems verspricht eine neue nachhaltige Energiezukunft, gefährdet aber gleichzeitig Werte wie Sicherheit und Privatheit. Wie man diese Risiken gegen eine nachhaltigere Zukunft abwägen oder auch nur vergleichen kann, ist eine schwierige Frage, auf die das Orientierungswissen der Technikfolgenabschätzung (TA) eine Antwort geben muss Dieser Beitrag untersucht, was der Capability Approach (CA) als Basis eines solchen Orientierungswissens leisten kann. Dies geschieht mit Hilfe zweier Szenarien als Fallbeispiele für die Digitalisierung im Energiesektor, einem Szenario zu Smart Grids und einem zum autonomen Fahren.

Keywords: Capability Approach, energy transition, digitalization, ethics, autonomous driving

This is an article distributed under the terms of the Creative Commons Attribution License CCBY 4.0 (https://creativecommons.org/licenses/by/4.0/) https://doi.org/10.14512/tatup.28.1.52

Submitted: 13.11.2018. Peer reviewed. Accepted: 14. 02.2019
The digital revolution in the energy sector is promised to aid a transition towards a sustainable energy future (Muench et al. 2014; Fleischer and Schippl 2018). In two sectors of the energy system - electricity and transportation - digital technologies already play an important role and increase the connection and integration of the two segments. For example, smart grids promise to ensure network stability despite the growing use of intermittent wind and solar energy; smart or autonomous cars promise a reduction of emissions and immediate benefit of improved road safety. However, digitalization raises new security and privacy risks. In the energy sector, these may become particularly severe as the high dynamics of the digital era meets long-lasting electrical or mobility infrastructures (Droste-Franke et al. 2015). This increases the danger of lock-in effects as changes in the energy sector are often seen as hardly reversible.

Any technology assessment (TA) of the digitalization of the energy sector needs to address questions such as to how to weigh the value of sustainability that aggregates over generations against individualistic impacts such as privacy (Rat für Nachhaltige Entwicklung 2018). Sustainability considerations may ask to integrate more intermittent renewable energies, such as wind or solar; smart grids may be the only way to deal with the intermittency, but the data-intensive system structures come at the price of significantly lower levels in privacy. Such conflicts raise particular challenges for TA's orientation knowledge ${ }^{1}$, as it needs to square or at least compare the privacy concerns that arise on the level of individuals with the seemingly aggregated

1 TA as other problem-oriented approaches, commonly distinguish three different types of knowledge: system knowledge to better understand the causeeffects relations in a system, orientation knowledge that provides both normative orientation and future oriented reflections (scenarios), and instrumental knowledge to identify feasible and effective policy options (interventions). 
value of sustainability that aggregates over generations. In this paper, we aim to explore how the Capability Approach (CA) can provide a normative framework for TA's orientation knowledge, as the CA was suggested to provide an individualistic basis for sustainability considerations (Hillerbrand 2018).

To do so, firstly, we outline the foundations of the CA. Secondly, we demonstrate how the CA could be used in a normative assessment of technological change by analyzing two future scenarios for digitalization in the energy sector, smart grids and automated driving. We chose cases from the electricity and transport sectors as these are the ones where ICT plays the biggest role within the energy system. Our analysis is intended as an illustration how the CA puts the focus on aspects of technologies that are not addressed at all, or not centrally, either in a framework based on stated preferences or based on common sustainability considerations. It thus provides not only a new individualistic and intersubjective basis for orientation knowledge, but also asks for a different focus in the debate on the energy transition.

\section{A Capability-Framework for TA}

The CA offers a normative framework for the assessment of individual human wellbeing and of social arrangements. The basic units for assessing quality of life are the individual's 'capabilities', which refer to what a person is able to do in her life. The freedom to choose and to actively realize what one has reason to value is seen as intrinsically valuable (Sen 1992). According to the CA, a well-lived human life is a life in which central decisions are up to the person herself. Taking the CA as the basis for orientation knowledge of TA implies firstly that the individual is the central unit of evaluation. The CA thus provides an in- man well-being, it also allows us to consider alternative courses of action. This gives reversibility or rather close(st)-to-reversibility of human actions a value in itself.

There are many variants of the CA (see Leon 2017 for an overview and a more detailed account of the CA); we hold that Nussbaum's version provides a normative foundation for TA's information knowledge in a way that alleviates the tensions depicted in the first section (Hillerbrand and Goldammer 2018). Influenced by Aristotelian thinking, Nussbaum puts human dignity at the center of her account of the CA and derives the following "central human capabilities" that are indispensable for a well-lived human life (Nussbaum 2006, pp. 76-78)2:

1. Life and bodily health: the ability to live one's life to its "natural" end, which involves being able to achieve a state of good health, including adequate nourishment, reproductive health, and adequate shelter;

2. Bodily integrity: the ability to live free from oppression, e.g., to be able to move freely between places and enjoy sexual and other bodily pleasures;

3. Emotions: the ability to form attachments with things and people outside oneself;

4. Trust: the ability to build meaningful bonds with others;

5. Senses, imagination, and thought: the ability to use the senses, to imagine, think, and to reason, including the ability of scientific and artistic expression;

6. Practical reason: being able to form a conception of the good and to engage in critical reflection about the planning of one's life;

7. Affiliation: being able to connect and care about oneself (i.e., a foundation of self-respect) and others (i. e., concern for others, social engagement);

\section{The Capability Approach provides an individualistic foundation for sustainability - commonly perceived as an aggregated concept.}

dividualistic foundation for the concept of sustainability, which is commonly perceived as an aggregated concept (Hillerbrand 2018). This enables to address conflicts between, for example, issues of privacy raised by introducing smart grids, and sustainability considerations that stress the need to integrate more intermittent renewable energies such as wind or solar. Secondly, the CA answers to a central challenge inherent to sustainability considerations, i.e. the empirical inaccessibility of the preferences of future generations. It is intersubjective capabilities, i. e. what a person is able to do and be with her live, that provide the central unit of normative evaluation, not the person's preferences as in, for example, many participatory approaches to TA. participatory approaches to TA. Thirdly, with its central focus on capabilities the CA not only takes into account the impacts a certain arrangement of energy sources may have on various aspects of hu-
8. Other species: the ability to be concerned and feel connected to non-human species;

9. Play: the ability to engage in recreational activities;

10. Control over one's environment: the ability of political engagement and to claim property.

This version of the CA provides an individualist, but intersubjective value theory. It is important to note that the CA is attentive to the inevitable diversity of human beings by taking into account that individuals differ in their capacities to make use of goods and resources. At the same time, the CA assumes that capabilities can be defined in an intersubjective way. These core

2 For a critique of Nussbaum's list see Barclay 2003; Sen 2004; Crocker 2008; Robeyns 2016. 
capabilities hence are not subject to trade-offs in democratic discourse; they are non-negotiable and of intrinsic value to humans qua humans as they are seen as necessary for developing individual freedoms (e. g. Nussbaum 2006).

In the following section, we explore how the CA can be applied as a normative framework for TA. We do this by illustrating how Nussbaum's core capabilities can serve to evaluate two specific technological developments related to the digitalization in the energy sector. While TA-studies commonly consider some core capabilities such as life or bodily integrity, others may be less obvious. For example, resettlement due to climate change or lignite production as well as fears of radiation hazards impact emotions. Control over one's environment also includes being able to participate and shape essential infrastructures (see Hillerbrand and Goldammer 2018 for more details).

\section{Evaluating technological developments with a capability- theoretic approach}

For our illustrative assessment of digitalization in the energy sector using Nussbaum's core capabilities, we chose two hypothetical but plausible future scenarios for smart grids and automated driving. While there are a number of different scenarios or visions for the future of both technologies (IEA 2011, 2015; Balta-Ozkan et al. 2014; Fleischer and Schippl 2018), we focus on two scenarios that combine a high degree of digitalization with comparatively sustainable future mobility and electricity systems as in these scenarios the tensions between the aggregated level of sustainability considerations and individualistic impacts are very pronounced. Hence, we are not concerned with the likelihood of these trajectories to become reality, but more with a demonstration of how Nussbaum's core capabilities might be affected by them.

We firstly introduce smart grids and the chosen scenario. Then we highlight the scenario's impact on selected core capabilities. We follow the same structure for automated driving. In selecting several core capabilities, we concentrated on those that we think highlight most clearly aspects that are not central to other assessment frameworks such as those based on stated preferences or aggregated sustainability indicators and at the same time illustrate trade-offs between the individual and the societal level.

\section{Digitalizing electricity networks}

Smart grids such as smart metering, home energy management systems, or household batteries are seen as important enabling systems in the transition to low-carbon electricity systems (Muench et al. 2014). While facilitating the integration of solar and wind energy, smart grids raise concerns regarding, for example, consumer data privacy, security, and a loss of control to IT systems (Milchram et al. 2018 a). For our purpose, we chose the scenario "Smart 2050" developed by Balta-Ozkan et al. (2014) in which a high degree of digitalization builds on strong consumer engagement and coherent policy action.

The scenario assumes that in 2050, the United Kingdom's electricity sector has undergone a transition towards a low carbon system. The combination of top-down policy interventions and a public willingness to engage with energy issues has led to achieving targets for renewable generation and emissions reduction. Electricity is generated from a wide range of renewable sources: both offshore and onshore wind, photovoltaic systems, biomass, tidal stream and wave power; gas-fired power plants are used at peak demand and are required to be equipped with carbon capture and storage technologies; nuclear power stations and a small amount of coal-fired power stations (fitted with carbon capture and storage) provide baseload generation. Among consumers, there is broad consensus that energy systems need to change to combat climate change and that this change is largely funded by energy bills. Smart meters have been installed and the benefits become clearer as consumers begin to understand how their energy use fluctuates throughout the day. A large share of the population has grown up with in-home displays and energy management systems that are controllable via phone and computer applications. The functionalities of in-home displays have grown and there is now a market for devices that interact with household appliances. Electric vehicles and heat pumps are very common and tend to cluster (i.e. they are not evenly spread out across the country). Demand side measures including variable tariffs are widely accepted and facilitate the integration of intermittent renewables, electric vehicles, and heat pumps by shifting demand over time and reducing demand.

The following paragraphs highlight how this scenario might impact several of Nussbaum's core capabilities:

\section{Senses, imagination, and thought}

The ability to think and reason is fundamentally affected by the scenario. Consumers are enabled to reflect on how their behavior impacts energy use, supported by intelligent meters and in-home displays that allow insights into fluctuations in daily and seasonal energy use and make energy demand transparent through smartphone and computer applications.

At the same time, reasoning about their energy use depends largely on technologies that are controlled by private companies. If the transparency of prices, energy use, or the companies' use of consumers' personal and energy consumption data is hampered in any way, the ability to reason is simultaneously lessened.

\section{Trust}

Digital systems facilitate communication about pricing between energy providers and consumers and offer consumers more transparent insight into their energy use and bills. This might have a positive impact on consumers' trust in energy companies, particularly given that historically consumer trust in energy providers in the UK is very low and that this low trust is often attributed to faulty and opaque billing (Milchram et al. 2018b). 
High consumer trust, however, implies higher vulnerabilities to the misuse of digital systems. If consumer trust is exploited and consumers react by using fewer smart grid technologies and refusing to participate in demand response activities, the stability of the entire electricity network is endangered.

\section{Control over one's environment}

The transparent insight into real-time energy use for consumers not only increases consumers' ability to think and reason about their trust towards energy companies but also allows consumers greater control over their energy use. For example, in-home displays showing real-time energy prices enable consumers to use certain household appliances at times when electricity prices are with a comparatively sustainable future mobility system. A similar scenario was published in Truffer et al. (2017) and Schippl et al. (2018).

In the Scenario "Smart mobility 2050", automated vehicles enable a highly flexible mobility-on-demand system for personal transport. In urban areas, and to a lesser extent also in rural areas, personal mobility is organized via platform/smartphones, based on different, but highly integrated options such as robo-taxis, autonomous buses, trams, autonomous cars or bicycles. Autonomous vehicles are generally perceived as useful, safe and efficient. Accessibility still matters; people do not take fewer trips than before. The developments in the mobility sector co-evolved with an overarching societal paradigm of a sharing

\section{The very idea of the Capability Approach is to maximize the freedom to choose between different options.}

low. Consumers are enabled to use appliances when there is an abundance of renewable energy, and are thereby equipped with greater control over their carbon footprint.

The individualistic perspective of the CA also draws attention to the question who the individuals are that benefit. In this scenario, relatively expensive technologies like electric vehicles and heat pumps cluster geographically, most likely in areas that are more affluent. Thus, the benefits of increased autonomy and control might only be available to affluent consumers. This may also impact how the electricity grid is financed: it is publicly owned, paid for through network tariffs that are part of each electricity bill. If affluent consumer groups can reduce their dependency on - and thus their payments for - the main electricity grid, the financial burden for this public infrastructure is shifted to those consumers who are unable to afford their own electricity generation.

\section{Digitalization, automation and the future of mobility}

Automated driving has become one of the most debated topics in the transport sector within only a few years (Fleischer and Schippl 2018). Many optimistic expectations are linked in particular to self-driving cars (Skinner and Bidwell 2016; BCG 2015). These expectations include a reduction in the number of accidents, better traffic flow, more efficient usage of infrastructures, more energy efficient driving, new options for use of travel time, better mobility for disabled persons, and also competitive advantages for the automotive sector. On the other hand, there are concerns related to a common unease many people have in interacting with "robots", concerns related to safety and security, data protection and hacking, as well as an overall increase in car traffic because car usage might become more attractive (Givoni et al. 2018). For the purposes of this article, we will focus on a scenario that combines a high degree of digitalization economy. Using instead of owning is generally perceived as efficient and in a way fashionable. In the scenario, we have very low shares in private car-ownership. The vast majority of people in urban areas do not have a driver's license. In the self-driving cars and robo-taxis, it is not the users who decide about which route to take; the entire navigation is done by the platforms. Users tell the platform where they want to go and follow the instructions. This is a highly data-intensive system that comes along with a high willingness of the users to provide personal data for a good service. It is a low carbon system; motorized mobility services are based on electricity that comes mostly from renewable energies. In urban areas, public money is still used to subsidize public transport and to keep it competitive. In growing urban areas there is a strong societal and political interest in using space that was occupied by traffic to develop green and livable cities. Cities are highly appreciated as places to live and most citizens are very interested in joining opportunities for participative city development.

The scenario description already indicates how different core capabilities may be affected. While in parts this does not come as a surprise (cleaner transport leads to cleaner air and supports a healthier life, for example), some additional insights become visible and invite a more in-depth analysis. The following core capabilities are particularly illustrative:

\section{Life and bodily health}

Today's mobility solutions produce not just climate gases but also other pollutants such as NOx or noise, all of which pose a threat to human health and reduce life expectancy in European cities. It is quite obvious that the smart mobility system outlined in this scenario reduces these negative impacts of mobility on life, bodily health and bodily integrity. However, the very idea of the $\mathrm{CA}$, to maximize the freedom to choose between different options, makes us aware of another issue, namely that 
the smart mobility scenario may well lead to a lock-in situation. The ability to drive a car may be lost when driver's licenses are no longer needed and those who still have licenses do not use them. Moreover, the competencies required to organize a transportation system with thousands of individual car drivers may be lost as well. This may limit the range of future options, since such a trajectory seems hardly reversible, even when the system does no longer correspond with the preferences of future generations.

\section{Practical reason}

This category highlights the fact that mobility is a central element of daily life and key to the planning of one's own life. Therefore, crucial developments in the transport sector should be open to participation and public scrutiny. A certain degree of transparency in how the system works and performs is needed to allow for public participation and democratic control. The way the smart mobility system is governed is crucial to this aspect. A platform that integrates everything but is dominated by a single large player ("the Amazon of mobility") may efficiently provide seamless mobility services but prevent the necessary transparency and reduce citizens' influence on the further development of the system. It is imaginable that only shareholders would have a significant influence on the structure and performance of such a system. By contrast, a system based on various actors but with a public or publicly controlled institution in the driver's seat may strengthen the chances for citizens to reflect on and react to the performance of the system and to ensure a mobility system that gives them a broad scope of freedom for planning their lives..

\section{Control over one's environment}

Control over one's environment can be extended to a more general perspective on quality of life in urban areas that considers the performance of the transport system in relation to other aspects of urban design, which can be important for realizing ideas of a livable city. Taken from this perspective, cars in particular, but perhaps also other mobility infrastructures, may be perceived as a burden that reduces autonomy as regards urban development, since they consume space that could otherwise be used for other functions such as recreation or opportunities for socializing. However, ideas of what defines a "livable city" may differ between generations, and it could be argued that a well-balanced co-existence of multiple functions should allow for various activities or interests to unfold over time.

\section{Concluding discussion}

Applying the categories of the core capabilities to scenarios on smart mobility and smart grids we found that some relevant aspects are emphasized and become palpable that do not yet appear in the spotlight of TA analysis. One key issue is relevant for several core capabilities and related to the foundational idea of the CA of enabling the freedom to choose: the fundamental tension inherent in a data-intensive system that enables a high degree of flexibility and affordability in mobility and access to renewable energies for nearly everyone. On the one hand, such systems increases the possibility for individuals to choose from a broad range of mobility options and energy services, for example to make a variety of social contacts, to be given a high degree of freedom in creating personal social networks, or to benefit from lower energy prices when participating in demand response services. On the other hand, it is impossible for individuals to opt out of the data-intensive system without a massive reduction in options for mobility or without incurring the risk of paying more for one's electricity consumption. Similar lock-ins appear at the system level in both sectors. For society as a whole, the way back to a less data-intensive, rather disconnected system structure is only possible at high cost; it requires significant changes to mobility practices for individuals and to the way energy is produced, transmitted and consumed. It is then up to the democratic discourse to choose the balance between automation, privacy/security and performance. The CA is able to establish the basis for such decisions by illustrating the trade-offs and integrating both the individual and the societal level.

Our analysis further reveals that the CA does not offer a "linear metric" to assess developments in these fields. However, this is not to be expected in such complex and ambiguous contexts. The CA helps to frame useful categories for analysis and highlights issues that are highly relevant for the daily life of citizens and thus (co-)determine acceptability - but are usually underrepresented in sustainability assessment. Particularly the CA's focus on issues relevant for the individual offers an enriching perspective compared to sustainability assessment that operates mostly with aggregated indicators.

The work presented in this paper is a first attempt to illustrate the suitability of the CA to evaluate future technological developments and thus amend existing TAs. In the course of this, Nussbaum's capabilities needed to be interpreted in a way that they become context-sensitive to the digitalization of infrastructures. These interpretations are indicative and were not developed with a participatory approach. However, in Nussbaum's CA democratic considerations are needed to firstly specify the core capabilities of the relevant context; and secondly to operationalize the capabilities. Further research should also consider if and how citizen participation is useful in the context-specific interpretation of capabilities, if the CA is to comply with the democratic principles of TA. Further open questions when using the CA as normative orientation for TA concern their operationalization and aggregation as well as when and in which assessment processes the CA is to be used. The results presented in this paper illustrate that it is well worth undertaking such research, particularly as the future will confront us and those carrying out TA studies with even more intensive processes of digitalization in all fields of daily life that challenge the democratic embedding of TA and its normative ladenness. 


\section{References}

Balta-Ozkan et al. (2014): Scenarios for the development of smart grids in the UK. Synthesis report. London: UKERC.

Barclay, Linda (2003): What kind of liberal is Martha Nussbaum? In: SATS Northern European Journal of Philosophy 4 (2), pp. 5-24.

BCG - Boston Consulting Group (2015): Self-driving-vehicle features could represent a $\$ 42$ billion market by 2025. Available online at https://www.bcg. com/d/press/8jan2015-self-driving-vehicles-market-2025-832, last accessed on 10.05.2017.

Crocker, David (2008): Ethics of global development. Agency, capability, and deliberative democracy. Cambridge: Cambridge University Press.

Droste-Franke, Bert et al. (eds.) (2015): Improving energy decisions. Towards better scientific policy advice for a safe and secure future energy system. Cham: Springer.

Fleischer, Torsten; Schippl, Jens (2018): Automatisiertes Fahren. Fluch oder Segen für nachhaltige Mobilität? In: TATuP - Zeitschrift für Technikfolgenabschätzung in Theorie und Praxis 27 (2), pp. 11-15. DOI: 10.14512/tatup.28.2.11

Givoni, Moshe; Fleischer, Torsten; Schippl, Jens (2018): Interview with Prof. Moshe Givoni. Self-driving cars are completely the wrong tool for me!. In: TATUP Zeitschrift für Technikfolgenabschätzung in Theorie und Praxis 27 (2), pp. 68-71. DOI: 10.14512/tatup.27.2.68.

Hillerbrand, Rafaela (2018): Why affordable clean energy is not enough. A capability perspective on the sustainable development goals. In: Sustainability 10 (7), p. 2485. DOI: 10.3390/su10072485.

Hillerbrand, Rafaela; Goldammer, Kathrin (2018): Energy technologies and human well-being. Using sustainable design for the energy transition. In: Albrecht Fritzsche and Sascha Oks (eds.): The future of engineering. Cham: Springer, pp. 151-175.

IEA - International Energy Agency (2011): Technology roadmap smart grids. Available online at https://webstore.iea.org/technology-roadmap-smartgrids, last accessed on 16.10.2018.

IEA (2015): How 2 guide for smart grids in distribution networks roadmap development and implementation. Available online at https://webstore. iea.org/how2guide-for-smart-grids-in-distribution-networks, last accessed on 16.10.2018.

Leon, Dorian (2017): Capability approach. A formal introduction. In: Journal of Economics and Political Economy 4 (2), pp. 216-18.

Milchram, Christine; van de Kaa, Geerten; Doorn, Neelke; Künneke, Rolf (2018 a): Moral values as factors for social acceptance of smart grid technologies. In: Sustainability 10 (8), p. 2703. DOI: 10.3390/su10082703.

Milchram, Christine; Hillerbrand, Rafaela; van de Kaa, Geerten; Doorn, Neelke; Künneke, Rolf (2018 b): Energy justice and smart grid systems. Evidence from the Netherlands and the United Kingdom. In: Applied Energy 229, pp. 1244-1259. DOI: 10.1016/j.apenergy.2018.08.053.

Muench, Stefan; Thuss, Sebastian; Guenther, Edeltraut (2014): What hampers energy system transformations? The case of smart grids. In: Energy Policy 73, pp. 80-92.

Nussbaum, Martha Craven (2006): Frontiers of justice. Disability, nationality, species membership. Cambridge, MA: Belknap Press.

Rat für Nachhaltige Entwicklung (2018): Nachhaltig und digital. Nachhaltige Entwicklung als Rahmen des digitalen Wandels. Empfehlung des Rates für Nachhaltige Entwicklung an die Bundesregierung. Available online at https://www.nachhaltigkeitsrat.de/wp-content/uploads/2019/01/20181219_ RNE_Empfehlung_Digitalisierung.pdf, last accessed on 07.02.2019.
Robeyns, Ingrid (2016): Capabilitarianism. In: Journal of Human Development and Capabilities 17 (3), pp. 397-414.

Schippl, Jens; Fleischer, Torsten; Truffer, Bernhard (2018): Exploring potential impacts of societal dynamics on the development of autonomous cars. Paper presented at the $7^{\text {th }}$ Transport Research Arena TRA 2018. Vienna, Austria, 16.-19. 04.2018

Sen, Amartya (1992): Inequality reexamined. Oxford: Clarendon Press.

Sen, Amartya (2004): Capabilities, lists and public reason. In: Feminist Economics 10 (3), pp. 77-80.

Skinner, Rachel; Bidwell, Nigel (2016): Making better places. Autonomous vehicles and future opportunities. N. p.: WSP, Parsons Brinckerhoff in association with Farrells.

Truffer, Bernhard; Schippl, Jens; Fleischer, Torsten (2017): Decentering technology in technology assessment. Prospects for socio-technical transitions in electric mobility in Germany. In: Technological Forecasting and Social Change 122, pp. 34-48. D0I: 10.1016/j.techfore.2017.04.020.

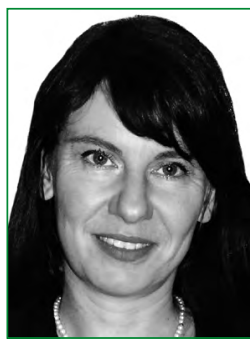

PROF. DR. DR. RAFAELA HILLERBRAND holds two doctorate degrees, one in physics and one in philosophy. Since 2015, she is professor for philosophy of engineering and technology at KIT. Her interdisciplinary research is located at the intersection between epistemology and ethics; one research focus is on how to act responsibly in the light of uncertainties and risks associated with technological progress.

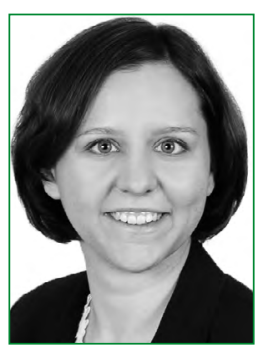

\section{CHRISTINE MILCHRAM}

has been working as a PhD researcher at the faculty of Technology, Policy and Management at Delft University of Technology (Netherlands) since 2016. Her research focuses on values and acceptability of smart grid systems, with a special interest for those systems' implications for energy justice.

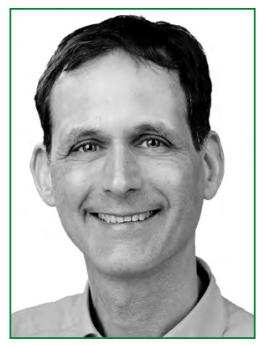

\section{JENS SCHIPPL}

studied geography, biology and of sociology at Heidelberg University. Since 2006 he works at the Institute of Technology Assessment and Systems Analysis (ITAS) at Karlsruhe Institute of Technology (KIT). His research interests encompass sociotechnical processes of change, foresight and technology assessment in the mobility sector. 


\section{Transparenz normativer Orientierungen in partizipativen TA-Projekten}

Ein Software-basierter Ansatz

Clemens Mader, Abteilung Technologie und Gesellschaft, Eidgenössiche Materialprüfungs- und Forschungsanstalt (Empa), Lerchenfeldstrasse 5, 9014 St.Gallen (clemens.mader@empa.ch), (1D orcid.org/0000-0001-5366-5354

Lorenz M. Hilty, Institut für Informatik, Universität Zürich (hilty@ifi.uzh.ch), (1) orcid.org/0000-0001-5020-0586

Claudia Som, Abteilung Technologie und Gesellschaft, Empa (claudia.som@empa.ch), (1) orcid.org/0000-0002-8901-4104

Patrick Wäger, Abteilung Technologie und Gesellschaft, Empa (patrick.waeger@empa.ch), (1) orcid.org/0000-0002-2109-6553

In partizipativen TA-Projekten treffen Teilnehmende mit unterschiedlichen normativen Orientierungen aufeinander. Wir stellen einen methodischen Ansatz vor, der alle Beteiligten dabei unterstützen soll, mit dieser Wertepluralität offen und transparent umzugehen, indem die Diskussion in einem Workshop mittels eines Online-Tools zur Befragung der potenziell Teilnehmenden vorbereitet wird. Die „LOTA“ (Landscape of Opinions for Technology Assessment) genannte Methode stützt sich auf globale Ziele, die den Teilnehmenden als normativer Referenzrahmen vorgegeben werden. Diese können Ziele auswählen und priorisieren und auf diese Weise ihre normativen Orientierungen ausdrücken. Das gleichnamige Software-Tool visualisiert eine "Meinungslandschaft" basierend auf den Daten aus der Online-Befragung.

Transparency of normative orientations in participatory TA projects A software-based approach

Participatory TA projects typically bring together people with diverse normative orientations. We present a methodological approach intended to support participants in dealing with the plurality of values in a transparent way by using an online tool to prepare for the discussion. The method called "LOTA" (Landscape of Opinions for Technology Assessment) is based on global goals which are presented to the participants as a normative frame of reference. By prioritizing global goals, the participants can express their normative orientations. The software tool visualizes the "landscape of opinions" resulting from the survey.

Keywords: technology assessment, participation, normative orientation, sustainable development, software

This is an article distributed under the terms of the Creative Commons Attribution License CCBY 4.0 (https://creativecommons.org/licenses/by/4.0/)

https://doi.org/10.14512/tatup.28.1.58

Submitted: 14.11.2018. Peer reviewed. Accepted: 13. 02.2019

\section{Einleitung}

In der Technikfolgenabschätzung (TA) geht es ,um das Spannungsverhältnis zwischen neuen Technikentwicklungen, Gesellschaft und Umwelt" (Open TA-Blog 2018). Bei einem Zeithorizont von mehreren Generationen ist TA zudem im Vorsorgeprinzip verankert und demzufolge der Leitidee der nachhaltigen Entwicklung sehr nahe (Som et al. 2009). TA-Projekte müssen sich aus einer Vielzahl von Gründen mit der normativen Dimension auseinandersetzen (Torgersen 2018). Schon die Wahl eines Zeithorizonts, in dem die Folgen der zur Debatte stehenden Technikentwicklung betrachtet werden, ist eine wertende und damit implizit normative Entscheidung, weil damit zukünftig lebende Menschen als potenziell Betroffene ein- oder ausgeschlossen werden. Ähnliches gilt für die Setzung eines geographischen oder geopolitischen Horizonts in TA-Projekten.

Der Einbezug von gesellschaftlichen Gruppen in die TA kann aus unterschiedlicher Motivation gewählt werden: um Politikberatung zu verbessern und zu bereichern, um zum öffentlichen Dialog beizutragen oder auch um den Prozess des Designs und der Entwicklung der Technik selbst zu unterstützen (Grunwald 2019). Der Fokus der hier vorgestellten Arbeit liegt auf Hilfsmitteln, die dies fördern können, indem sie dabei unterstützen, einen Überblick über die Werthaltungen der Teilnehmenden einer Diskussion zu gewinnen.

In solchen partizipativen TA-Prozessen gelangen Teilnehmende oft zu unterschiedlichen Einschätzungen der Erwünschtheit einer technischen Entwicklung, ohne aber zu verstehen, weshalb sie unterschiedlicher Meinung sind. Fehlt dieses Verständnis, wird eine Chance zur Reflexion des eigenen Standpunktes und damit auch auf eine Annäherung der Standpunkte vertan. Erfahrungsgemäß verfügen Teilnehmende nicht über ein gemeinsames Vokabular, mit dem sie ihre Werthaltungen expli- 
zit ausdrücken könnten. Der hier vorgestellte Ansatz, die LOTA-Methode (Landscape of Opinions for Technology Assessment), beruht deshalb auf der Idee, das Vokabular aus existierenden Dokumenten zu gewinnen, die aus einem breit abgestützten politischen Prozess hervorgegangen sind. Die zwei vielleicht wichtigsten Quellen sind die Allgemeine Erklärung der Menschenrechte und die Ziele für Nachhaltige Entwicklung (SDGs) der Vereinten Nationen.

Unser Ansatz unterscheidet sich von der Multikriteriellen Entscheidungsanalyse (MCDA, z. B. Scholten et al. 2014), obwohl es einige Gemeinsamkeiten gibt. Gemeinsam ist den beiden Ansätzen, dass Wertfragen explizit thematisiert werden, um mit Pluralität konstruktiv umzugehen. Anders als bei MCDA ist es jedoch nicht Ziel von LOTA, Güterabwägungen zu quantifizieren und mittels eines mathematischen Modells Prognosen und Präferenzen zu kombinieren, um robuste Alternativen zu ermitteln, sondern vielmehr eine Diskussion zu fördern, in der ein reflektierteres Verständnis der verschiedenen Positionen wachsen kann und im Idealfall eine Dynamik in Richtung Konsens in Gang kommt.

In diesem Beitrag wird als Beispiel für die Anwendung des methodischen Ansatzes die Technik der autonomen Lieferdrohnen verwendet. Dieses Beispiel, auf Basis eines Testlaufs mit einer Gruppe von Studierenden, dient zur Illustration der Methode.

\section{Partizipation, Werte und Transparenz in der TA}

In den letzten Jahrzehnten wurden verschiedene Methoden für die TA entwickelt oder genutzt, wie Innovative TA (Ropohl 1996), Constructive TA (Schot und Rip 1996), Real Time TA (Guston und Sarewitz 2002), Leitbildorientierte Technikgestaltung (Gleich 2004), Consensus Conferences, Scenario Workshops, Publiforen, Publifocus, Foresight oder Bürgerbeteiligung (Klüver et al. 2000; Joss und Bellucci 2002; Hennen et al. 2004). Diese Ansätze kann man grob in „Experten-TA“ und ,partizipative TA“ einteilen (Sclove 2010). Letztere lassen sich weiter unterscheiden in Verfahren, bei denen Stakeholder einbezogen werden und Verfahren, bei denen die allgemeine Öffentlichkeit einbezogen wird (Bürgerberatung), wenngleich häufig gemischte Formen vorkommen (Grunwald 2019).

Die Folgen einer technischen Entwicklung sollen in einer möglichst frühen Entwicklungsphase abgeschätzt werden (Simonis 2013), damit die Grundlagen und Optionen für informierte Entscheidungen rechtzeitig bekannt sind. Entscheidungen der Weiterentwicklung müssen also unter hoher Unsicherheit getroffen werden und haben in Gesellschaften mit pluralen Wertvorstellungen (Mader und Leitenberger 2016) bei hohem technischem Entwicklungstempo oft weitreichende Folgen (Klüver et al. 2000; Som et al. 2009; Bütschi 2012).

Betrachtet man TA als eine Form der anwendungsorientierten Forschung, so gilt auch hier die Erfahrung aus partizipati- ven Forschungsansätzen, dass Missverständnisse zwischen den verschiedenen teilnehmenden Gruppen entstehen und zu einem Vertrauensverlust führen können. Es ist deshalb wichtig, eine gemeinsame Sprache zu entwickeln, um konstruktiv gemeinsam an Lösungen arbeiten zu können (Engels und Walz 2018). Partizipative Forschung und TA stehen deshalb vor einer doppelten Herausforderung: Sie müssen erstens dem Pluralismus förderliche Bedingungen im Forschungsprozess herstellen und zweitens das Vertrauen in die Forschungsergebnisse wahren, indem sie Transparenz bezüglich Interessen und Werthaltungen der eingebundenen Akteure wie auch der Forschenden sicherstellen. Die Meinungsbilder sollten sowohl in der Forschung als auch unter den teilnehmenden Akteuren transparent gemacht werden, da sie Auswirkungen auf die Ergebnisse der Technikbewertung an sich haben (Kerschner und Ehlers 2016).

\section{Die LOTA-Methodik im TA-Prozess}

„LOTA“ (Landscape of Opinions for Technology Assessment) soll zur Bewältigung der oben beschriebenen Herausforderungen beitragen. LOTA soll den Beteiligten insbesondere helfen zu erkennen, aus welchen Gründen sie die Chancen und Risiken einer Technik unterschiedlich beurteilen. Prinzipiell können diese Gründe den folgenden zwei Kategorien angehören:

1. Die Teilnehmenden gehen von unterschiedlichen deskriptiven Voraussetzungen aus, d. h. sie schätzen die faktischen Möglichkeiten, Grenzen oder die konkrete Ausgestaltung zukünftiger Anwendungen unterschiedlich ein.

2. Die Teilnehmenden gehen von unterschiedlichen normativen Voraussetzungen aus, d.h. sie bewerten die aufgrund von (1) erwarteten Folgen der vorgestellten Technikanwendung in unterschiedlichen Wertesystemen. Dies kann in einem partizipativen Prozess zu situativen Wertungskonflikten führen (Weydner-Volkmann 2019).

Bestandteil von Wertesystemen sind, neben ethischen und rechtlichen, insbesondere moralische Werte, also ,,jene Werte, die den fundamentalen Bedürfnissen und legitimen Erwartungen und Interessen entsprechen, die Menschen (und allenfalls einige Tiere) haben“ (Bleisch und Huppenbauer 2011, S. 42). Das Wertesystem, auf das sich eine Person beim Einschätzen einer Frage von gesellschaftlicher Bedeutung bewusst oder unbewusst bezieht, bezeichnen wir im Folgenden als die „,normative Orientierung" dieser Person.

Die LOTA-Methode unterstützt die Diskussion in partizipativen TA-Projekten, indem sie - in einer dem ersten Zusammentreffen vorgelagerten Online-Befragung - unter anderem die normativen Orientierungen der Teilnehmenden erfasst. Die Ergebnisse werden visualisiert und an die Teilnehmenden zurückzugeben. Die eigentliche Diskussion, die im Rahmen eines Workshops stattfindet, kann somit in Kenntnis der „Meinungslandschaft“ der Teilnehmenden erfolgen. Diese ist dem Konzept 
der „moralischen Landkarte“ (Weydner-Volkmann 2019) verwandt. Indem die Teilnehmenden sehen können, wie sich beispielsweise die an globale Ziele vergebenen Prioritäten in der Gruppe verteilen, werden sie sich der unterschiedlichen normativen Orientierungen in der Gruppe bewusst.

Ein weiterer erwünschter Effekt der vorgelagerten Online-Befragung besteht darin, dass der oder die Moderierende die Daten dazu verwenden kann, nur einen Teil der Befragten für die Teilnahme am Workshop auszuwählen. Dadurch wird es möglich, die Umfrage unter einer wesentlich größeren Zahl von Personen durchzuführen, als für eine gute Interaktion im Workshop wünschbar ist. Mit Hilfe einer Clusteranalyse kann die Moderatorin oder der Moderator Cluster ähnlicher Meinungen bilden und von jedem Cluster eine kleine Zahl an Repräsentierenden (1-3) einladen. Durch diese Heuristik erhöht sich die Chance auf eine reichhaltige Diskussion, in der ein breites Spektrum von Positionen vertreten ist und möglichst alle Argumente zur Sprache kommen.

Bei der Entwicklung der LOTA-Methode war ein zentrales Problem zu lösen: Mit welchem Vokabular, mit welchen Kategorien und im Rahmen welcher normativen Ideale sollen normative Orientierungen explizit erfragt und transparent gemacht werden? Hierfür bieten sich aus der bisherigen Praxis die folgenden Möglichkeiten an:

1. Mit dem Vokabular der Ethik. Diese Option stellt allerdings hohe Anforderungen an die Artikulationsfähigkeit der Teilnehmenden. Außerdem ist es ein weiter Weg, die Implikationen ethischer Positionen für die jeweiligen konkreten Fragen zu analysieren, oder umgekehrt, aus typischen Entscheidungssituationen durch Abstraktion „für ähnliche Entscheidungssituationen wiederkehrende Wertungskonflikte" (Weydner-Volkmann 2019, S. 42) zu gewinnen. Für spezifischere Kontexte mag dies gelingen. Einen interessanten $\mathrm{Zu}-$ gang wählt Vetter (2018) mit der „Matrix for Convivial Technologies". Diese fragt vorgegebene Designkriterien ab, die auf einer bestimmten normativen Position - der Ethik der Konvivialität - beruhen und diese konkretisieren.

2. In psychologischen Kategorien. In diesem Fall könnten subjektive Werthaltungen der Teilnehmenden mit existierenden psychologischen Tests erhoben werden. Eine solche „Psychologisierung" normativer Orientierungen - obwohl sie in anderen Verfahren nicht unüblich ist - könnte jedoch die Diskussion über Wertvorstellungen auf eine Diskussion über situative oder individuelle Präferenzen reduzieren. Damit wären moralische Urteile als entscheidender Bestandteil normativer Orientierung nicht von Präferenzen unterschieden. Wer sich zu moralischen Fragen äußert, tut dies in der Überzeugung, damit ein allgemein verbindliches Prinzip zu vertreten, das er selbst dann einhalten müsste, wenn er dabei gegen eigene Präferenzen und Interessen handelte. Gerade deshalb ist die Diskussion normativer Hintergrundannahmen so wichtig für eine ethische Entscheidungsfindung (Bleisch und Huppenbauer 2011). Nach unserer Auffassung leisten Ansätze, die auf Einstellungen basieren (wie z. B. Kerschner und Ehlers 2016) dies nicht.

3. Durch Bezugnahme auf einen existierenden Rahmen normativer Ideen, die sich international als weitgehend konsensfähig erwiesen haben. Hierzu gehören insbesondere die Allgemeine Erklärung der Menschenrechte (UDHR) und die Ziele für nachhaltige Entwicklung (SDGs) der Vereinten Nationen. Auch weithin verwendete Indikatorensysteme wie der Human Development Index (HDI) oder der Happy Planet Index (HPI) können mit den Kriterien, auf die sie sich stützen, eventuell zu einem gemeinsamen Vokabular beitragen.

Dieser dritte Weg ist jener, den wir mit dem LOTA-Ansatz explorativ beschreiten. Konkret haben wir alle vier oben genannten ,globalen Zielsysteme“ (UDHR, SDGs, HDI, HPI) als Quellen verwendet. Hierbei sei angemerkt:

- Dadurch, dass wir diese Zielsysteme in den Prozess einbringen, werden sie nicht normativ vorausgesetzt. Im Gegenteil: Wir schaffen damit eine Gelegenheit für die Teilnehmenden, sich explizit für oder gegen die darin enthaltenen Ziele zu entscheiden. Beispielsweise können Teilnehmende das globale Ziel „Wohlstand“ in ihre Liste prioritärer Ziele aufnehmen und das Ziel „Gesunde Umwelt“" explizit nicht, oder umgekehrt. Das vorgegebene Zielsystem dient lediglich als „Koordinatensystem“, in dem sich die Teilnehmenden normativ verorten können.

- Dass wir die in den Zielsystemen vorkommenden Themen grundlegend für relevant halten, ist jedoch eine unvermeidbare normative Setzung. Sollte es aber vorkommen, dass Teilnehmende das für sie relevante Thema im gegebenen „Koordinatensystem“ überhaupt nicht vorfinden, besteht die Möglichkeit, ein eigenes Ziel zu formulieren.

- Die Tatsache, dass es sich um globale Ziele handelt, also keine Einschränkung auf nationale oder lokale Kontexte vorgesehen ist, ist ebenfalls eine bewusste normative Setzung, wie in der Einleitung bereits erwähnt. Es ist Teil unseres Ansatzes, TA so zu verstehen, dass die Folgen einer technischen Entwicklung für den ganzen Planeten betrachtet werden sollen.

- Es ist prinzipiell möglich, die Zielsysteme, die wir verwenden, durch andere zu ersetzen und den Ansatz dadurch zu generalisieren.

Die Inhalte der SDGs, der allgemeinen Erklärung der Menschenrechte und die Teilindikatoren für HDI und HPI haben wir nach inhaltlicher Analyse wie folgt zu neun globalen Zielen aggregiert: (1) Sicherung der Grundbedürfnisse; (2) Freiheit und Selbstbestimmung; (3) Sicherheit und Frieden; (4) Gesunde Umwelt; (5) Zugang zu Bildung und Information; (6) Rechtsstaatlichkeit; (7) Gleichheit; (8) Wohlstand; (9) Globaler Konsens und Governance.

Jedes der neun Ziele ist mit einer Sammlung von Auszügen der globalen Zielsysteme in der Originalformulierung hinter- 
legt, auf die sich das jeweilige Oberziel abstützt. Diese Sammlung kann beim Ausfüllen des Fragebogens durch die Teilnehmenden mit einem Mausklick abgerufen werden und dient zur Erläuterung der Oberziele. Die Teilnehmenden können die Liste der Oberziele außerdem individuell ergänzen.

Zur Erhebung normativer Orientierungen wurde ein Fragebogen entwickelt, in welchem die Befragten - unter anderem - aus den genannten globalen Zielen eine Teilmenge auswählen. Anschließend sollen sie die Auswahl nach Priorität ordnen. Es gehört zu der Methode, dass die Teilnehmenden gezwungen werden, selektiv zu sein. Wir hoffen, damit Unterschiede in den normativen Orientierungen zu detektieren. In der derzeitigen Version der Software besteht außerdem ein Zwang, die ausgewählten Ziele in eine strikte Rangordnung zu bringen. Die Erfahrung wird zeigen, ob es eventuell notwendig ist, auch die Gleichwertigkeit von Zielen zuzulassen.

\section{Fallbeispiel Lieferdrohne}

Die LOTA-Methode wird anhand des Fallbeispiels „Lieferdrohne“ in vier Schritten beschrieben. Vorbereitend legt der oder die Moderierende fest, wie viele Ziele die Befragten als Priorität auswählen dürfen. Die Anzahl bestimmt die Komplexität und damit die Dauer des Prozesses. Im folgenden Beispiel konnten Teilnehmende zwischen einem und vier Zielen auswählen.

\section{Schritt 1 (Phase I der Online-Befragung)}

Auswahl und Priorisierung der Ziele, Beantwortung weiterer Fragen zur Einschätzung der Dringlichkeit und langfristigen Gültigkeit der Ziele sowie zur Einschätzung der Chancen und Risiken der zur Diskussion stehenden Technik in Bezug auf die ausgewählten Ziele. Die relativ große „Abstraktionslücke“ zwischen den allgemeinen globalen Zielen und der jeweiligen Technik (hier: Lieferdrohnen) wird durch die individuelle Einschätzung der Teilnehmenden gefüllt. Hier ist bewusst keine Anleitung oder Führung vorgegeben.

\section{Schritt 2 (Auswertung Phase I der Online-Befragung)}

Visualisierung der Ergebnisse der Befragung für jede teilnehmende Person in Radardiagrammen (Abb. 1), wobei die eigene Einschätzung (schwarz) und die durchschnittliche Einschätzung der Teilnehmenden (grün) angezeigt werden; pseudonymisierte Visualisierung der Meinungslandschaft basierend auf einer Clusteranalyse (Abb. 2). Diese Darstellung kann die Moderatorin oder der Moderator z. B. verwenden, um eine Teilmenge der Personen für die Teilnahme am weiteren Prozess auszuwählen. Insbesondere lässt sich die Pluralität der Meinungen in den nachfolgenden Schritten maximieren, indem man von jedem Cluster mindestens eine Person einlädt.

In Abbildung 1 ist zu sehen, dass der Indikator ,Grad der Besorgnis“ bei dieser oder diesem Teilnehmenden in Bezug auf alle von ihr gewählten Ziele leicht höher als im Durchschnitt ist. Ferner erkennt sie Chancen der diskutierten Technik für alle Ziele außer für „Gesunde Umwelt“. Dass bei diesem Ziel der Durchschnittswert jedoch relativ hoch ist gibt bereits Anregun-

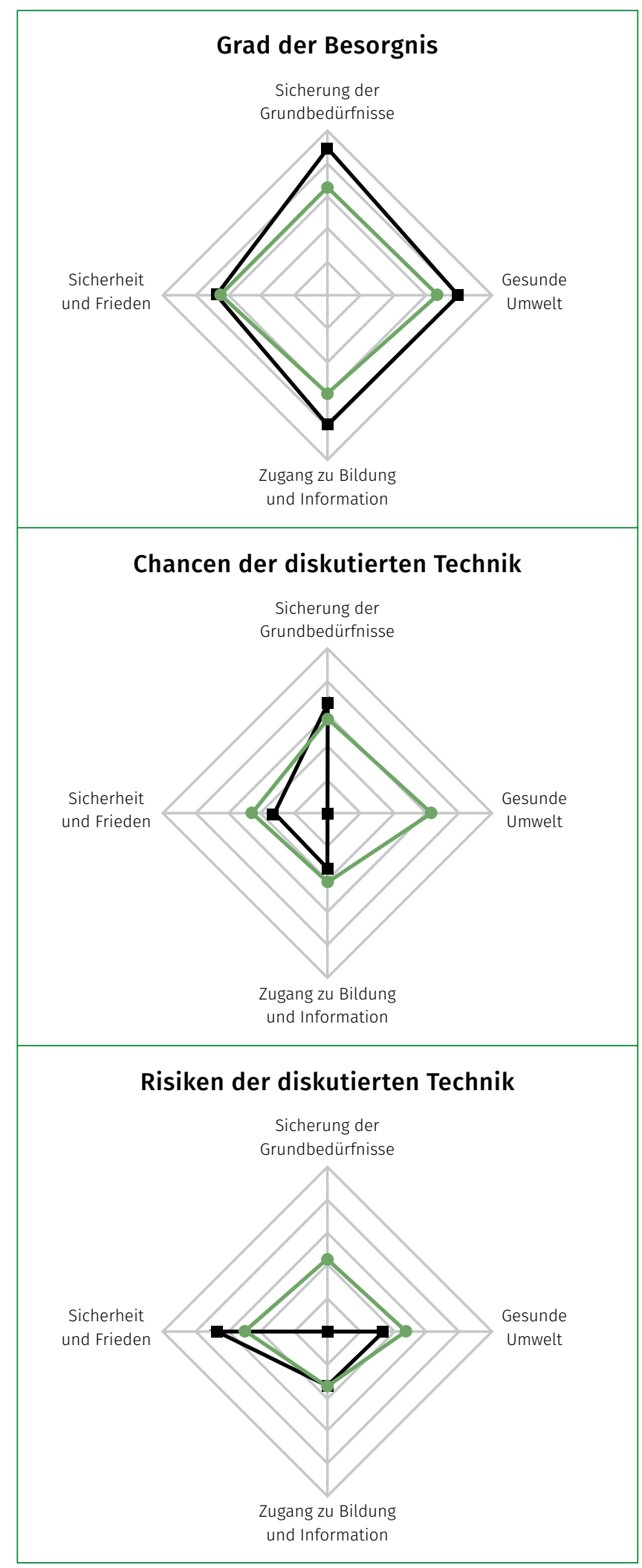

Abb. 1: Radar-Diagramme: zeigen für die ausgewählten Ziele drei Indikatoren, die aufgrund der eigenen Antworten berechnet wurden (schwarz) und den Mittelwert über alle Teilnehmenden (grün) 


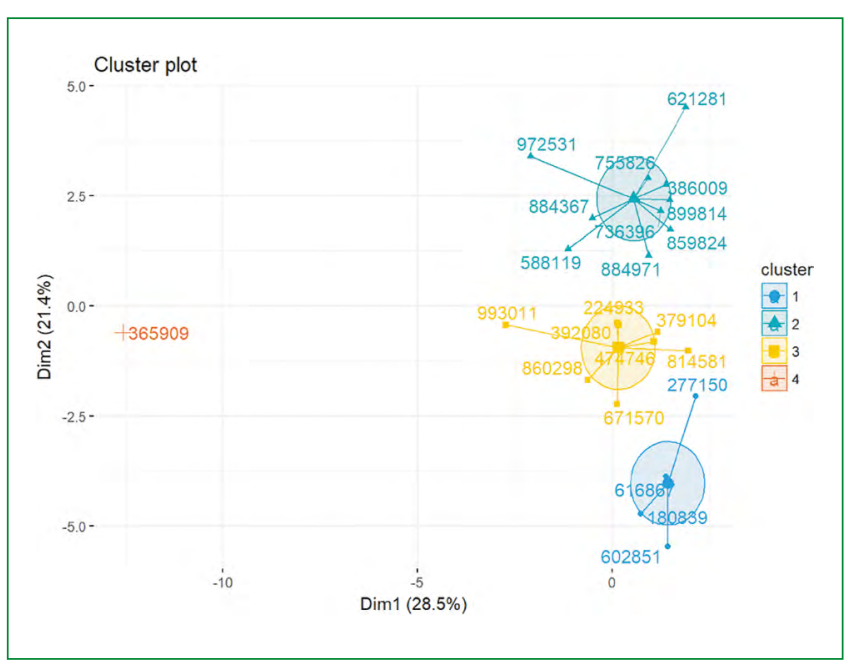

Abb.2: Pseudonymisierte "Meinungslandschaft": Ergebnis der ersten Phase der Online-Befragung. Die sechsstelligen Nummern stehen für Personen und sind nur diesen selbst bekannt. Quelle: Eigene Darstellung

gen für die spätere Diskussion. Ähnlich verhält es sich bei den Risiken, wo diese Person kein Risiko für die „Sicherung der Grundbedürfnisse" sieht, die Gruppe im Durchschnitt dagegen schon.

Abbildung 2 zeigt, wie die Teilnehmenden in einer Clusteranalyse aufgrund ihrer Antworten in Untergruppen eingeteilt werden. Das Verfahren lässt sich grob wie folgt beschreiben: Aufgrund der von ihr gegebenen Antworten kann jede Person als Punkt in einem n-dimensionalen Raum repräsentiert werden. Mit dem K-Means-Algorithmus werden, unter Verwendung der Euklidischen Distanz, ${ }^{1}$ Gruppen bzw. Cluster von möglichst ,ähnlichen“ Personen, also von nahe beieinander liegenden Punkten gebildet. Nur für die visuelle Darstellung der Cluster wird die Anzahl der Dimensionen auf zwei reduziert; die tatsächlichen Distanzen sind in dieser Projektion deshalb verzerrt. Es sind vier Cluster zu sehen, wobei das vierte Cluster (ganz links, orange) nur aus einer einzigen Person mit der Nummer 365909 besteht. Mit dem Ziel, unterschiedliche Positionen in den Diskurs zu integrieren, sollte diese Person aufgrund ihrer zu erwarteten Minderheitsmeinung auf jeden Fall zum Workshop eingeladen werden.

\section{Schritt 3 (Online-Befragung Phase II)}

Das System erstellt eine vereinigte Liste jener ausgewählten Ziele, die die höchste subjektive Relevanz für die Teilnehmenden hatten. Diese Liste ist in der Regel länger als die im Schritt 1 vorgegebene maximale Zahl von Zielen, kann in der Länge aber ebenfalls begrenzt werden. In unserem Beispiel umfasst diese

1 Bei diesem statistischen Verfahren wird aus einer Menge von Objekten eine vorher bekannte Anzahl von k Gruppen gebildet. Der Algorithmus ist eine der am häufigsten verwendeten Techniken zur Gruppierung von Objekten; er bevorzugt Gruppen mit geringer Varianz und ähnlicher Größe. vereinigte Liste sechs Ziele (die später in Abb. 3 zu sehen sind). Die zukünftigen Workshopteilnehmenden werden anschließend auch zu den Zielen befragt, die sie in Phase I selbst nicht ausgewählt hatten, die aber neu in der vereinigten Liste auftreten. Neben den Fragen aus Phase I werden vertiefende Fragen zu den Zielen und ihrer Interaktion (Impact Matrix nach Scholz und Tietje 2002) gestellt, deren Ergebnisse im Schritt 4 als „Impact Graph"visualisiert werden (Abb. 3).

\section{Schritt 4 (Auswertung Phase II der Online-Befragung)}

Visualisierung des Systems von Zielen einschließlich ihrer gegenseitigen Beeinflussung und des Einflusses der diskutierten Technik (Abb. 3). Diese Darstellung liegt zum Auftakt des Workshops schon vor und visualisiert die folgenden Informationen:

Zum einen zeigt die Größe eines Knotens einen Indikator, den wir „Relevanz“ nennen. Er beruht auf einer Aggregation der Antworten auf die folgenden Fragen: Wie wichtig ist dieses Ziel für das Leben der Menschen? Wie lange wird es wichtig sein? Wann werden verheerende negative Folgen auftreten, wenn das Ziel nicht erreicht wird?

Zum anderen zeigen die Pfeile die kausalen Einflüsse zwischen den Zielen und ebenso die Einflüsse der technischen Chancen und Risiken auf die Ziele, wie sie von den Teilnehmenden wahrgenommen werden. Die Dicke eines Pfeils zeigt die Stärke des Einflusses, wobei zunächst bewusst nicht unterschieden wird, ob der angenommene Kausalzusammenhang positiv oder negativ ist.

In dieser dritten Form der Visualisierung werden (im Gegensatz zu Abb. 1 und Abb. 2) nun Mittelwerte über alle Teilnehmenden visualisiert. Die Helligkeit eines Knotens oder Pfeils zeigt zudem die Standardabweichung an: Dunkelgrüne Knoten oder Pfeile zeigen maximale Übereinstimmung an; je heller der Grünton, desto höher die Abweichung unter den Teilnehmenden.

Aus Abbildung 3 lässt sich unter anderem ablesen, dass dem Ziel „Gesunde Umwelt" die höchste Relevanz zugeschrieben wurde, dass die Meinungen hierzu jedoch stark auseinandergehen (hellgrün). „Gleichheit“" bekommt die geringste durchschnittliche Relevanz, hat jedoch den stärksten Einfluss auf „Freiheit und Selbstbestimmung“ und einen deutlichen Einfluss auf „Gesunde Umwelt“: Die Gruppe scheint diesem Ziel eine höhere indirekte als direkte Relevanz zuzuschreiben. Allein das Betrachten der Abhängigkeiten der Ziele untereinander kann interessante Fragen für die Diskussion aufwerfen.

Betrachtet man nun zusätzlich, welchen Einfluss die Teilnehmenden den ,,autonomen Lieferdrohnen“ zuschreiben (repräsentiert durch die horizontalen Pfeile von links und rechts, differenziert nach positivem und negativem Einfluss, d. h. Chancen und Risiken), ergibt sich ein Meinungsbild über die Einschätzung dieser technischen Entwicklung vor dem Hintergrund der globalen Ziele. Im hier gezeigten Fall ist abzulesen, dass relativ einhellig Risiken für „Freiheit und Selbstbestimmung“ gesehen werden. Chancen werden hauptsächlich für den ,Zugang zu Bildung und Information“, zur „Sicherung der Grundbedürfnisse“ und zu „Sicherheit und Frieden“" gesehen. 


\section{Ergebnis}

Indem die Teilnehmenden die Online-Befragung durchlaufen und die visuellen Auswertungen gesehen haben, können sie sich in der Diskussion darauf beziehen. Diese Bezugnahme erleichtert die vertiefende Diskussion insbesondere der normativen Orientierungen, die hinter den Einschätzungen von Chancen und Risiken stehen, damit aber auch die Diskussion deskriptiver Fragen, da diese sich nun klarer von normativen Fragen abgrenzen lassen. Die Rolle von LOTA als Werkzeug ist nach dem Auftakt des Workshops beendet; LOTA ist kein Debattier-Tool, sondern dient als ,Geburtshelfer" für eine transparente, reflektierte Diskussion.

Durch die Visualisierung von Meinungslandschaften hoffen wir, Bewusstsein für die Diversität der Standpunkte und ihren normativen Hintergrund $\mathrm{zu}$ schaffen. Dabei werden die Namen der Personen grundsätzlich nicht verwendet. Es bleibt damit den Teilnehmenden überlassen, ihre Standpunkte in der Diskussion zu erläutern und allenfalls freiwillig aus der Anonymität herauszutreten.

\section{Schlussfolgerungen und Ausblick}

Im Zuge der Forderung an die TA, zu nachhaltiger Entwicklung beizutragen (siehe unter anderem die Konferenzen TA18 und NTA8 im Jahr 2018), werden zugleich die Anforderungen an die Methodik der TA anspruchsvoller. Während es in der transdisziplinären Forschung zur Großen Transformation (WBGU 2016) vorwiegend um die Entwicklung von System-, Ziel- und Transformationswissen für neue Umsetzungsideen und -maßnahmen geht, geht es in der TA um die Abschätzung von Wirkungen von Technikanwendungen. Es ist deshalb wesentlich, ein möglichst breites Spektrum an normativen Orientierungen in TA-Studien einfließen zu lassen. Unser Ansatz kann hier nur einen Baustein beisteuern, ohne den Anspruch zu erheben, alle Aspekte umfassend abzudecken. In einer explorativen Anwendung unter Studierenden haben wir positive Effekte auf die Diskussion beobachtet. Die gegebenen Zielsysteme haben die Teilnehmenden offensichtlich inspiriert, mögliche Anwendungen der diskutierten Technik - hier autonome Lieferdrohnen - in einem breiteren Rahmen zu diskutieren, als dies in konventionellen TA-Workshops üblicherweise der Fall ist. Tests unter den realen Bedingungen eines TA-Projekts sind für das Jahr 2019 geplant.
LOTA soll Geburtshelfer eines pluralistischen und normativ transparenten Diskurses sein und dabei eine globale Perspektive einbringen. Damit trägt die Methode nicht nur zu einer besseren Belastbarkeit der Ergebnisse einer TA bei, sondern unterstützt auch die Selbstreflexion der beteiligten Forschenden, welche in ihrer Rolle als „honest broker“ (Pielke 2007) zusätzlich zu ihrer Rolle als Moderierende auch authentische politische Empfehlungen abgeben sollen. Die Diskussion über mögliche Widersprüche, die hier mitschwingen können, ist nicht neu (Hennen et al. 2004) und soll mit unserem Ansatz nicht ignoriert, sondern im Gegenteil durch den Vorschlag einer neuen Praxis inspiriert werden.

\section{Literatur}

Bleisch, Barbara; Huppenbauer, Markus (2011): Ethische Entscheidungsfindung.

Ein Handbuch für die Praxis. Zürich: Versus Verlag.

Bütschi, Danielle (2012): Knowledge-based policy making. Report of the first parliamentary TA debate held in Copenhagen on June 18, 2012. Bern: TA-Swiss. Online verfügbar unter http://www.pacitaproject.eu/wp-content/ uploads/2012/10/PACITA_4.2_1st-Debatre_report_def_print-version.pdf, zuletzt geprüft am 25. 02.2019.

Engels, Anita; Walz, Kerstin (2018): Dealing with multi-perspectivity in real-world laboratories. In: GAIA 27 (S1), S. 39-45.

Gleich, Arnim von (2004): Leitbildorientierte Technikgestaltung. Nanotechno-

logie zwischen Vision und Wirklichkeit. In: Stefan Böschen, Michael Schneider und Anton Lerf (Hg.): Handeln trotz Nichtwissen. Frankfurt am Main: Campus, S. 159-188. 
Grunwald, Armin (2019): Technology assessment in practice and theory. London: Routledge.

Guston, David; Sarewitz, Daniel (2002): Real-time technology assessment. In: Technology in Society 24, S. 93-109.

Hennen, Leonhard; Petermann, Thomas; Scherz, Constanze (2004): Partizipative Verfahren der Technikfolgen-Abschätzung und parlamentarische Politikberatung. Arbeitsbericht Nr. 96. Berlin: TAB.

Joss, Simon; Bellucci, Sergio (2002): Participatory technology assessment. European perspectives. London: Centre for the Study of Democracy University Westminster.

Kerschner, Christian; Ehlers, Melf-Hinrich (2016): A framework of attitudes towards technology in theory and practice. In: Ecological Economics 126, S. 139-151.

Klüver, Lars et al. (2000): EUROpTA. European participatory technology assessment. Methods in technology assessment and technology decision-making. Kopenhagen: The Danish Board of Technology.

Mader, Clemens; Leitenberger, Anna-Theresa (2016): Relevanz von Stakeholdereinbindung im Nachhaltigkeitsassessment. Die Nachhaltigkeitsprofilmatrix. In: Reinhard Altenburger und Roman Mesicek (Hg.): CSR und Stakeholdermanagement. Wiesbaden: Springer, S. 93-107.

Open TA-Blog (2018): Ein Gespräch mit Dr. Stephan Lingner. Online verfügbar unter https://www.openta.net/blog/ZumTA-VerständnisundderTAPraxisderEAEuropeanAcademy.94, zuletzt geprüft am 14. 01.2019.

Pielke Jr., Roger (2007): The honest broker. Making sense of science in policy and politics. Cambridge: Cambridge University Press.

Ropohl, Günther (1996): Ethik und Technikbewertung. Berlin: Suhrkamp.

Scholten, Lisa; Egger, Christoph; Zheng, Jun; Lienert, Judith (2014): Multikriterielle Entscheidungsanalyse. Neue Ansätze für langfristige Infrastrukturplanung in der Wasserver- und -entsorgung. In: Aqua \& Gas 5, S. 62-69.

Scholz, Roland; Tietje, Olaf (2002): Embedded case study methods. Integrating quantitative and qualitative knowledge. Thousand Oaks, CA: Sage Publications.

Schot, Johan; Rip, Arie (1996): The past and future of constructive TA. In: Technology Forecasting and Social Change 54, S. 251-268.

Sclove, Richard (2010): Reinventing technology assessment. A 215t century model. Washington, DC: Woodrow Wilson International Center for Scholars.

Simonis, Georg (Hg.) (2013): Konzepte und Verfahren der Technikfolgenabschätzung. Wiesbaden: Springer VS.

Som, Claudia; Hilty, Lorenz; Köhler, Andreas (2009): The precautionary principle as a framework for a sustainable information society. Journal of Business Ethics 85 (3), S. 493-505.

Torgersen, Helge (2018): Die verborgene vierte Dimension. In: TATuP - Zeitschrift für Technikfolgenabschätzung in Theorie und Praxis 27 (1), S. 21-27. DOI: 10.14512/tatup.27.1.21.

Vetter, Andrea (2018): The matrix of convivial technologies. Assessing technologies for degrowth. In: Journal of Cleaner Production 197 (2), S. 1619-1886. WBGU (2016): Humanity on the move. Unlocking the transformative power of cities. Berlin: WBGU.

Weydner-Volkmann, Sebastian (2019): Ethische TA als Kartographie situativer Wertungskonflikte. In: TATuP - Zeitschrift für Technikfolgenabschätzung in Theorie und Praxis 28 (1), S. 39-44. D0I: 10.14512/tatup.28.1.39.

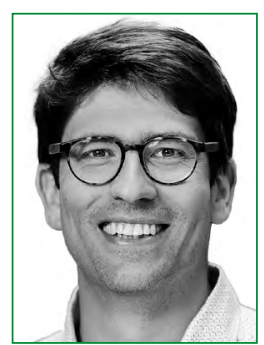

\section{DR. CLEMENS MADER}

ist wissenschaftlicher Mitarbeiter in der Abteilung für Technologie und Gesellschaft der Empa in St. Gallen, sowie im Nachhaltigkeitsteam der Universität Zürich. Er forscht zu Transdisziplinarität, Nachhaltigkeitsprozessen, sowie TA im Bereich Digitalisierung.

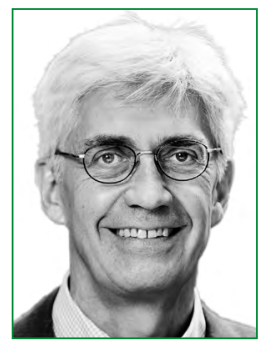

PROF. DR. LORENZ M. HILTY

ist Professor am Institut für Informatik der Universität Zürich und Gruppenleiter in der Abteilung für Technologie und Gesellschaft der Empa in St. Gallen. Seine Forschungsgebiete sind TA im Bereich Digitalisierung sowie IKT-basierte Methoden und Werkzeuge für die Nachhaltigkeitsforschung.

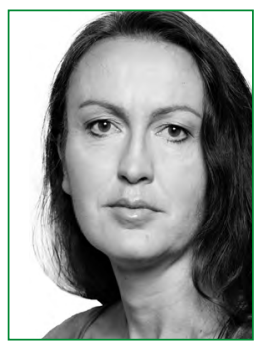

\section{CLAUDIA SOM}

ist Senior Scientist in der Abteilung für Technologie und Gesellschaft der Empa. Sie forscht auf dem Gebiet der TA und nachhaltige Innovation mit Schwerpunkten in den Bereichen Nanotechnologie und Biopolymere.

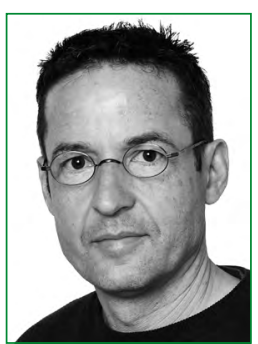

\section{DR. PATRICK WÄGER}

leitet die Abteilung Technologie und Gesellschaft der Empa, welche erforscht, unter welchen Bedingungen neue Materialien und Technologien die Transition zu einer nachhaltigeren Gesellschaft unterstützen können. 